\title{
A búza (Triticum aestivum L.) glutamin szintetáz enzim viselkedése abiotikus stresszfolyamatok ( szárazság- és az alumíniumstressz) során
}

\author{
Doktori (Ph. D.) értekezés
}

\section{Nagy Zoltán}

\section{Témavezető:}

Dr. Pécsváradi Attila

egyetemi docens

Biológia Doktori Iskola

Szegedi Tudományegyetem

Természettudományi és Informatikai Kar

Növénybiológiai Tanszék

Szeged

2013 


\section{Tartalomjegyzék}

Rövidítések jegyzéke .................................................................................................... 4

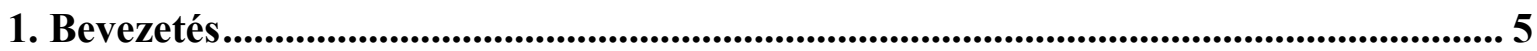

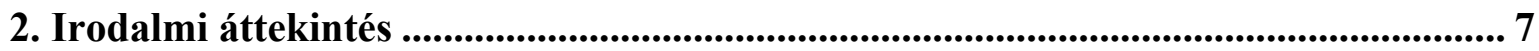

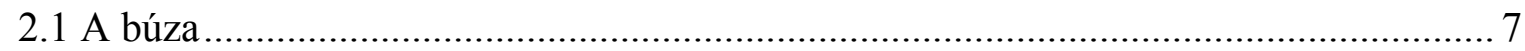

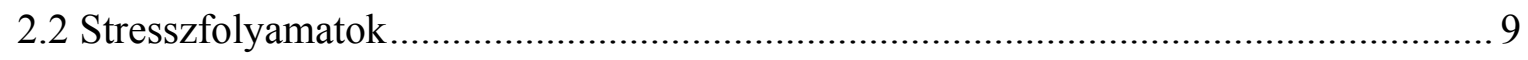

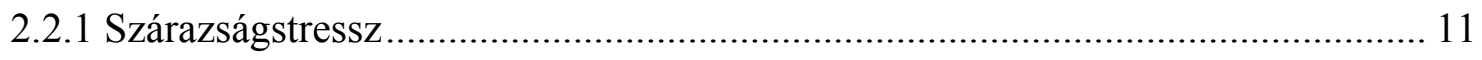

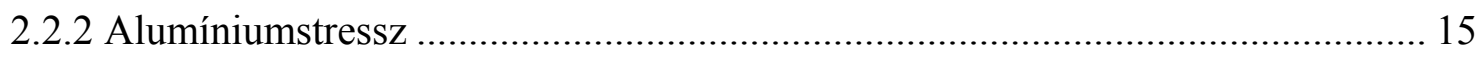

2.3 A növények szén és nitrogén anyagcseréjének kapcsolata....................................... 21

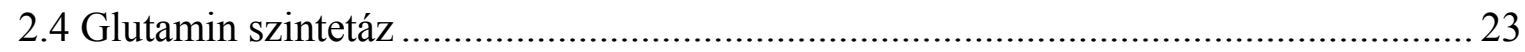

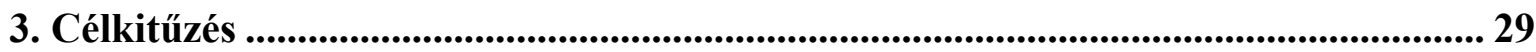

4. Anyagok és módszerek ................................................................................................................. 31

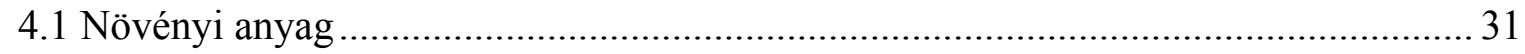

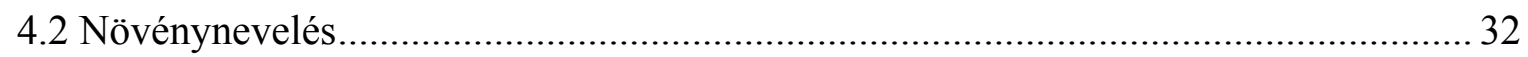

4.2.1 Szárazságstressz vizsgálathoz alkalmazott növénynevelés .............................. 32

4.2.2 Alumíniumstressz vizsgálatához alkalmazott növénynevelés ............................ 33

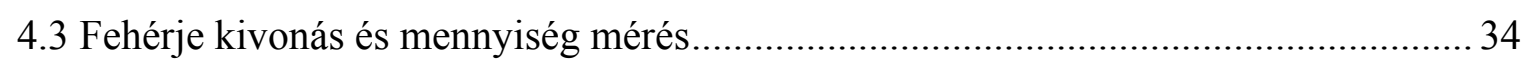

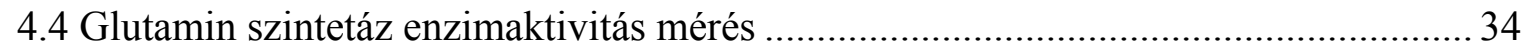

$4.5 \mathrm{Az}$ alumínium hatásának vizsgálata a GS aktivitására ............................................. 35

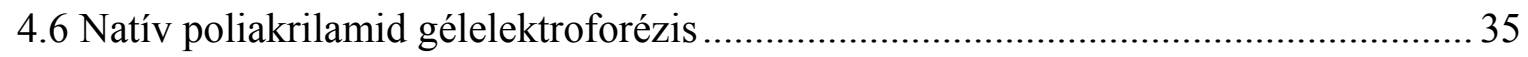

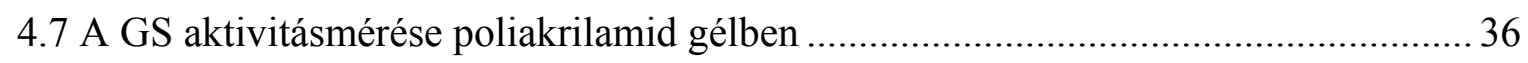

4.8 Poliakrilamid gélek festése, szárítása, dokumentálása ............................................ 37

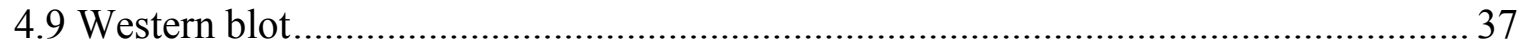

4.10 Az alumínium és magnézium detektálása............................................................ 38

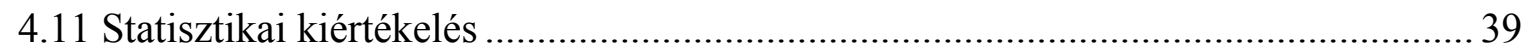

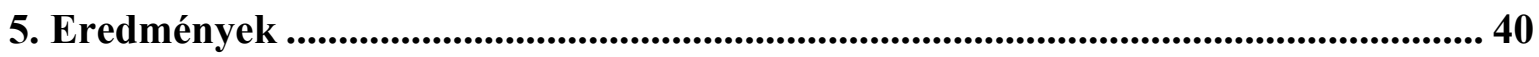

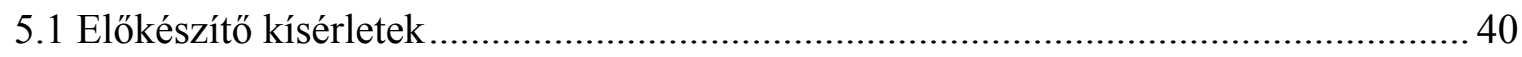

5.1.1 A GS izoenzimek lokalizációja poliakrilamid gélben ....................................... 40

5.2 A szárazságstresszhez kapcsolódó vizsgálatok eredményei..................................... 42

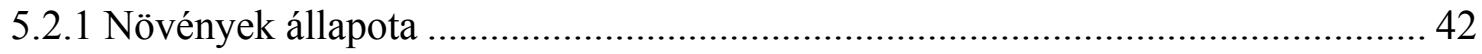




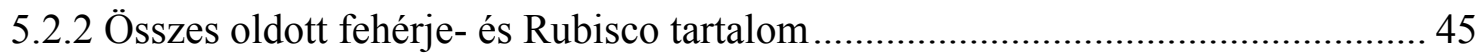

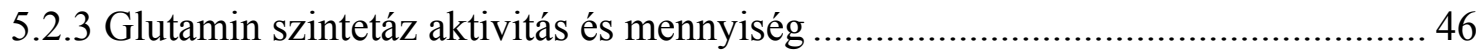

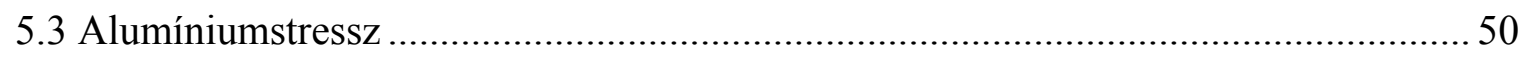

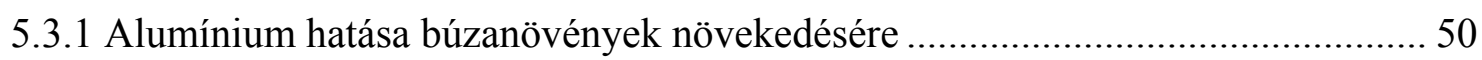

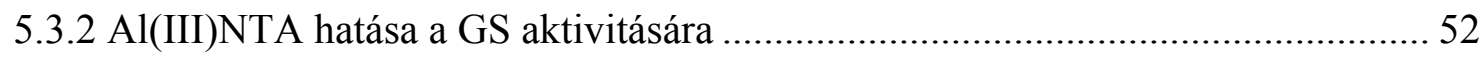

5.3.3 Alumínium és magnézium mennyisége az Al(III)NTA-val kezelt GS-ben.......... 54

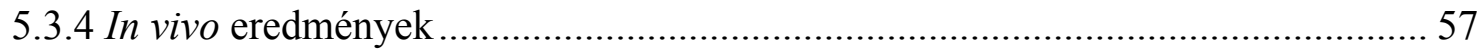

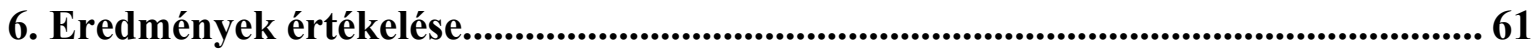

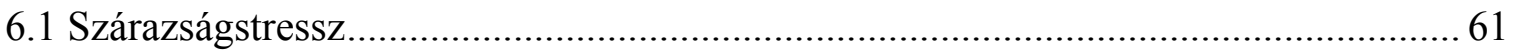

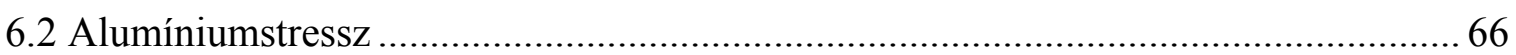

6.2.1 Különböző szerves savak alumínium komplexeinek hatása a GS aktivitására..... 66

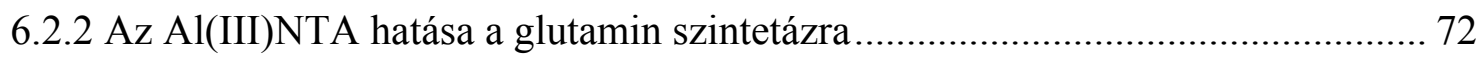

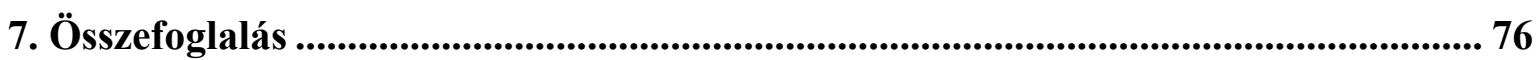

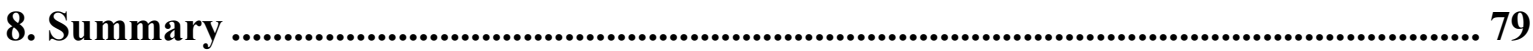

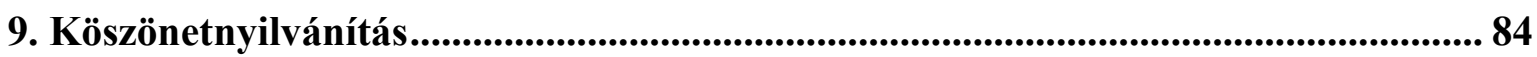

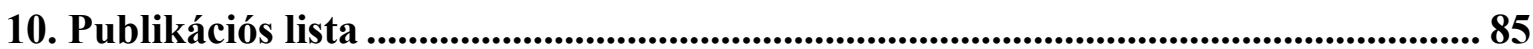

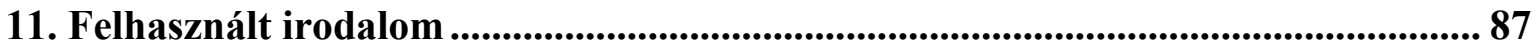




\section{Rövidítések jegyzéke}

ABS - abszcizinsav

ADP - adenozin-difoszfát

AI(III)NTA - nitrilo-triecetsav alumínium komplex

APS - ammónium-perszulfát

AS - aszparagin szintetáz

ATP - adenozin-trifoszfát

BCIP - 5-bromo-4-kloro-3'-indolilfoszfát

DPA - days post anthesis = anthézis után eltelt napok száma

DTT - ditio-treitol

EDTA - etiléndiamin-tetraecetsav

FT - friss tömeg

GDH - glutamát dehidrogenáz

GMH - $\gamma$-glutamil-monohidroxamát

GOGAT - glutamin-oxoglutarát aminotranszferáz, glutamát szintáz

GS - glutamin szintetáz

ICP-AES - induktív csatolású plazma atom emissziós spektrometria

$\mathbf{M e}^{2+}-$ bivalens fémion

NBT - nitro-blue-tetrazoliumklorid

NTA - nitrilo-triecetsav

PAGE - poliakrilamid gélelektroforézis

$\mathbf{P}_{\mathbf{i}}-$ anorganikus foszfát

PVDF - polivinilidén-difluorid

Rubisco - ribulóz-1,5-bifoszfát karboxiláz-oxigenáz

TBS - Tris pufferelt sóoldat

TCA - triklór-ecetsav

TEMED - tetrametiletiléndiamin 


\section{Bevezetés}

A növények fontos szerepet játszanak az emberiség életében. Az ismert történelem kezdete óta az élelmezésben, a ruházkodásban és az eszközkészítésben egyaránt nélkülözhetetlenek voltak a vadon található és a termesztésbe bevont tagjai a növényvilágnak, és jelentőségüket mind a mai napig meg is örizték. A növények helyhezkötött életmódja megköveteli, hogy a vegetatív és a generatív fejlödésük során a lehetőségeikhez képest gyorsan és hatékony módon tudjanak a környezethez alkalmazkodni. A mezőgazdasági termelés mennyiségi és minőségi alakulásában fontosak azok a körülmények, amikben a növények fejlödnek. A környezeti faktorokat két nagy csoportba tudjuk sorolni úgy, mint biotikus és abiotikus faktorok, azaz az élőlények által és az élettelen környezeti hatások által okozott változások. Dolgozatomban az abiotikus környezeti faktorok közül kettőnek a vizsgálatáról számolok be.

A hexaploid kenyérbúza (Triticum aestivum L.) az emberi élelmezés egyik alapvető fontosságú gabonája. A magyarországi mezőgazdasági termelésbe bevont területének is a nagy részét a búza vetésterülete teszi ki és nem csak az emberi élelmezésben, hanem az állati takarmányozásban betöltött szerepe is nagy. Genetikai kapcsolatban áll a már neolitikumban is termesztett tetraploid tönke búzával (T. turgidum L. ssp. dicoccon) és diploid alakorral (T. monococcum). De a tudatos domesztikáció hatására megváltozott a szármagassága, levélfelülete és ami a legfontosabb a termésmennyisége és minősége is. A kezdeti szelekcióknak mindig az volt a célja, hogy gyors növekedésü, életciklusú és nagy terméshozammal rendelkező növényeket hozzanak létre. Azonban mostanra fontossá vált a fajták szelekciójában a környezeti stresszhatásokkal szembeni ellenállóság is. A globális klímaváltozás következménye, hogy az extrém meteorológiai események, különösen az aszály kialakulásának gyakorisága növekszik. Egyértelmü igény van olyan fajtákra, amik a szélsőséges viszonyok között is nagyobb termésveszteség nélkül termeszthetőek. A növény életfunkcióinak jó indikátorai a fotoszintetikus folyamatok müködési paraméterei, a kloroplasztisz állapota, az egyes szervek fehérje tartalmai, a különböző hormon szintek, bizonyos gének kifejeződése. Az öregedési folyamatok sebessége is ad információt a stressz mértékéről és a növény adaptációs és akklimatizációs folyamatairól. Mint látható a környezeti stresszre adott reakciók nagyon összetett és bonyolult élettani és molekuláris lépések sorozata a környezeti jelek felfogásától a DNS transzkripción át a fehérjék 
megjelenéséig és végső soron a növény fizikai megjelenésében, vegetatív és generatív müködésében.

Kísérleteinkben arra kerestünk válaszokat, hogy a szárazság és alumínium okozta stressz hogyan befolyásolja a glutamin szintetáz mennyiségi viszonyait, illetve az enzim müködését. Ez a fehérje a növény szén és nitrogén anyagcseréjében egyaránt fontos szerepet tölt be. A szervetlen nitrogén források szerves molekulákba történő beépítésének folyamatában kulcsfontosságú. Ezért is volt jelentőségteljes számunkra, hogy a két szélsőséges környezeti helyzetben tudjuk vizsgálni ezt a fehérjét.

A vizsgálatainkhoz több Triticum aestivum búzafajtát is felhasználtunk. Ezek rezisztencia szintje jól ismert és vannak köztük gazdaságilag elterjedt genotípusok is. A vízmegvonásos kísérleteket kalászoló növényeken végeztük, míg az alumíniumos kezeléseket fiatal, egy hetes növényeken történtek. A kétféle kísérleti eljárásban kapott eredményeket összehasonlítottuk, és ez alapján kívántuk megállapítani a glutamin szintetáz szerepét az abiotikus környezeti hatások által kiváltott stresszfolyamatokban. 


\section{Irodalmi áttekintés}

\subsection{A búza}

A búza az egyik legfontosabb és legelterjedtebb mezőgazdasági haszonnövény a rizs és a kukorica után. A világ 40 országában a legnagyobb területen termesztett gabonaféle és az emberi populáció 35\%-ának a legfontosabb élelmiszernövénye. Megtalálható a Földünk mérsékelt, mediterrán, trópusi és szubtrópusi klimatikus területein egyaránt, mind az északi, mind a déli féltekén is, Norvégiától kezdve Argentínáig. Azonban a legnagyobb termést produkáló régiók a mérsékelt éghajlati övezetekben vannak (dél Oroszország, az Amerikai Egyesült Államok középső területei). A modern búzatermesztésben két fajt használnak kiemelkedő arányban: a hexaploid kenyérbúzát (Triticum aestivum L.) és a tetraploid durum búzát (Triticum turgidum L. ssp. durum). Jelenleg körülbelül 25000 genotípus létezik, de számuk folyamatosan növekszik (Nevo és mtsai. 2002). Az egész világon nagy vetésterülettel rendelkezik a búza és Magyarországon is a legfontosabb gabonaféle. Az $\mathbf{1}$. táblázatban is jól látható, hogy a gabonafélék között a betakarított területnek több mint egyharmada búza volt az elmúlt időszakban. Egyedül csak a kukoricát termesztik néhány ezer hektárral nagyobb területen hazánkban.

A fontosabb gabonafélék termesztése és felhasználása (2009-)

\begin{tabular}{|c|c|c|c|c|c|c|}
\hline \multirow{2}{*}{ Megnevezés } & \multicolumn{3}{|c|}{ Gabonafélék összesen } & \multicolumn{3}{|c|}{ Búza } \\
\hline & 2009 & 2010 & 2011 & 2009 & 2010 & 2011 \\
\hline \multicolumn{7}{|l|}{ A termelés jellemzői } \\
\hline Betakarított összes termés, tonna & 13590362 & 12261996 & 13678212 & 4419163 & 3745190 & 4106634 \\
\hline Termésátlag, kg/hektár & 4720 & 4730 & 5110 & 3850 & 3710 & 4200 \\
\hline
\end{tabular}

1. táblázat: Magyarország gabona- és búzatermesztési adatai a 2009-2011-es idöintervallumban a Központi Statisztikai Hivatal adatai alapján.

Forrás: www.ksh.hu/docs/hun/xstadat/xstadat eves/i omn001a.html (2013.03.03)

A közönséges vagy kenyérbúza (Triticum aestivum L.) egyéves vagy áttelelő egyéves egyszikủ növény a perjefélék (Poaceae) családjából. Az áttelelő életmód alapján tavaszi és őszi vetésű, illetve járó búza (ezek gazdasági jelentősége napjainkban kicsi) fajtákat különíthetünk el. Általánosan elmondható, hogy az őszi búzafajták nagyobb termésátlaggal 
rendelkeznek, mint a tavasziak, de a bokrosodás és a virágzás indukciójához hideghatás (vernalizáció) is szükséges. A búza a többi gabonaféléhez hasonlóan erőteljes mellékgyökérrendszert fejleszt. Hosszúnappalos körülmények között virágzik ez az északi féltekén májust, júniust jelent. Virágzata füzéres füzér, ahol búza esetében a füzért kalásznak, a füzérkét pedig kalászkának nevezzük. Elmondható, hogy önmegporzásra hajlamos virágzáskor, ugyanis a kalászkák kinyílása előtt megtörténik a portokokból a pollenek kiszabadulása és a bibe is megtermékenyíthető állapotban van már ilyenkor. A kifejlett növény szára üreges, magassága $40-150 \mathrm{~cm}$ között változik az egyes genotípusokban. A növény méretét környezeti hatások és a genetikai háttér is befolyásolja. A búzanövények terméshozamának két meghatározó pontja a terméskötés és a szemfeltöltődés folyamata. A terméskötés során dől el, hogy a kalászban hány szem mag alakul ki. A magok méretét és a tápanyagok mennyiségi és minőségi paramétereit pedig a szemfeltöltődés szabja meg. A búza zászlós levelének, ami a kalászhoz legközelebbi levél, kiemelkedő szerepe van a szemfeltöltődés fiziológiai folyamataiban.

A mezőgazdaságban a búza fejlődésének jellemzésére és értékelésére létrehozott skála a Zadoks skála. Ez egy decimális skála a gabonanövények egyes fejlödési szakaszait sorolja be 10-10 élettanilag jól jellemzett csoportba (Zadoks és mtsai. 1974). A 2. táblázatban a kísérleteink alapján fontosabbnak ítélt fejlődési szakaszok vannak felsorolva. Az alumínium stressz vizsgálatánál a 0-tól a 14-dik stádiumban lévő csíranövényeket, a szárazságstresszel kapcsolatos vizsgálatokban a 45-től 89-dik stádiumban lévő növényeket használtuk.

Az őszi búza fejlődését tekintve hosszú tenyészidejü növénynek számít, a szárazság stresszt jól viseli, a minimum csapadékigénye évi 400-500 mm, azaz jól türi a szárazságot, de a termés mennyiségét és minőségét jelentősen befolyásolja a vízhiány. A legmeghatározóbb ebből a szempontból a szemfeltöltődési időszak alatti csapadék hiány (Barnabás és mtsai. 2008). Magyarország a szárazföldi mérsékelt éghajlati övezetben fekszik, ennek velejárója a változékony időjárás, kiszámíthatatlan előre, hogy mely időszakban lehetséges aszály. Évenként váltakozva előfordulhat tavaszi, nyári és téli csapadék hiány is. Emiatt fontos, hogy a nemesítésben is olyan fajták kerüljenek létrehozásra, amelyek a fejlődésük minden szakaszában rendelkeznek a szárazságtürés képességével. Azonban fontos kiemelni, hogy a végső cél mégis az, hogy egy adott fajta a megfelelő minőségű nagyobb termés produkálására legyen képes a legszélsőségesebb körülmények között is. 


\begin{tabular}{|c|c|c|c|}
\hline Zadoks skála & Fejlődési stádium & Zadoks skála & Fejlődési stádium \\
\hline \multicolumn{2}{|r|}{ Csírázás } & \multicolumn{2}{|c|}{ A legfelső levélhüvely fejlődése } \\
\hline 0 & Száraz szem (vetés) & 41 & Zászlós levél hüvelye megnyúlik \\
\hline 3 & Csírázás, duzzadás vége & 43 & A zászlóslevél hüvelye vastagodni kezd \\
\hline 5 & Gyökér megjelenése & 45 & A zászlóslevél hüvelye megvastagodott \\
\hline 7 & Sziklevél megjelenése & 47 & A hüvely kinyílik \\
\hline 10 & Talajból való kitörés, első levél megjelenése & 49 & A kalász első szálkái láthatóak \\
\hline \multicolumn{2}{|r|}{ Csíranövény fejlődése } & \multicolumn{2}{|r|}{ A kalász fejlődése } \\
\hline 11 & Első levél kifejlődése & 50 & Az első kalászkák megjelenése \\
\hline 12 & Második levél kifejlődése & 53 & A kalász egynegyede kifejlődött \\
\hline 13 & Harmadik levél kifejlődése & 55 & A kalász fele kifejlődött \\
\hline 14 & Negyedik levél kifejlődése & 59 & A teljes kalász kifejlődött \\
\hline 15 & Ötödik levél kifejlődése & \multicolumn{2}{|r|}{ Virágzás (Anthezis) } \\
\hline 16 & Hatodik levél kifejlődése & 60 & Virágzás kezdete \\
\hline 17 & Hetedik levél kifejlődése & 65 & Füzérkék fele elvirágzott \\
\hline 18 & Nyolc vagy több levél látható a szár már hosszabodik & 69 & Virágzás vége \\
\hline \multicolumn{2}{|r|}{ Bokrosodás } & \multicolumn{2}{|r|}{ Tejesérés } \\
\hline 20 & Csak főhajtás & 71 & A szemek vizesérés állapotában vannak \\
\hline 21 & Főhajtás és egy oldalhajtás & 73 & Korai tejesérés \\
\hline 22 & Főhajtás és kettő oldalhajtás & 75 & Tejesérés közepe \\
\hline 23 & Főhajtás és három oldalhajtás & 77 & Késői tejesérés \\
\hline 29 & Főhajtás és kilenc vagy több oldalhajtás & \multicolumn{2}{|r|}{ Viaszérés } \\
\hline \multicolumn{2}{|r|}{ A szár növekedése } & 83 & Korai viaszérés \\
\hline 30 & Szárbaindulás & 85 & Puha táplálószövet (lisztes-test) \\
\hline 31 & Az első nódusz megjelenése & 87 & Kemény táplálószövet \\
\hline 32 & Második nódusz megjelenése & 89 & Élettani érettség \\
\hline 33 & Harmadik nódusz megjelenése & \multicolumn{2}{|r|}{ Érés } \\
\hline 37 & Zászlóslevél megjelenése & 91 & A szem kemény \\
\hline 39 & Zászlóslevél gallérjának megjelenése & 95 & A szemek nyugalmi állapotba kerülnek \\
\hline
\end{tabular}

2. táblázat: A gabonafélék egyes fejlödési stádiumai a Zadoks skála szerinti besorolásban Zadoks és mtsai. 1974 alapján.

\subsection{Stresszfolyamatok}

A stresszel kapcsolatos folyamatokat Levitt tanulmánya alapján szeretném röviden összefoglalni (Levitt 1972). Általánosan elmondható, hogy stressznek nevezünk minden nem specifikus választ egy élőlény részéről az őt ért kedvezőtlen, negatív ingerekre (stresszorok). Stressz érhet bármilyen élő szervezetet, azonban az ember vagy akár az állatok nagy része képes aktívan elkerülni a számukra káros körülményeket. A növények azonban helyhez kötött életmódjukból adódóan erre nem képesek, nekik folyamatosan alkalmazkodniuk kell a változó környezeti tényezőkhöz. Az alkalmazkodás molekuláris, sejt, szöveti és szervezeti szinten is megmutatkozhat.

A stresszfolyamatokkal kapcsolatban beszélni kell néhány alapfogalomról. Az első ilyen a stressztürőképesség (stressztolerancia), ez az élőlény állóképességét jelenti, ami 
által képes elviselni az őt érő káros hatásokat. Másik folyamat az akklimatizáció, erről akkor beszélünk, ha egy élőlény stressztürő képessége megnövekszik stressz hatására. Az adaptáció során pedig genetikailag alkalmazkodik az élőlény a számára kedvezőtlen környezeti körülményekhez.

A stresszfolyamatok kapcsán ki kell emelni azokat a főbb élettani stratégiákat, amelyek meghatározzák, hogy egy élőlény hogyan próbálja átvészelni a számára kedvezőtlen körülményeket (zárójelben az angol szakkifejezés olvasható):

- Menekülő stratégia (,escape”)

- Elkerülő stratégia (,,avoidance”)

- Toleráló stratégia (,,tolerance”)

A menekülő stratégiát alkalmazó élőlények esetében a kedvezőtlen körülmény hatására a lehető leggyorsabban befejezik az életciklusukat. Ennek a stratégiának élettani indikátora lehet a korai szárbaszökkenés, virágzás és termés érlelés, stressz indukált korai levélöregedés. Az elkerülő stratégia esetében a káros környezeti tényező hatását próbálják mérsékelni, késleltetni. Ilyen például az árterületen élő, a gyors vízsodrásnak, elárasztásnak kitett, növényeknél a gyors hajtásnövekedés, a víz áramlásának ellenálló levél és szár alak, szárazság stressz esetén a sztóma záródás, levelek összecsukódása. A tolerancia esetében pedig a környezet hatásainak elviselése történik meg például ozmoprotektáns fehérjék termelésével, nagyobb gyökérzet, nagyobb vízhasznosító képesség. Legtöbbször az elkerülő és toleráló stratégia nem választható el élesen egymástól, gyakran egy élőlényen megfigyelhetőek mindkét stratégiába illeszkedő élettani folyamatok, tulajdonságok (Meyre és mtsai. 2001, Puijalon és mtsai. 2011).

A kedvezőtlen környezeti hatásokat két nagy csoportba lehet sorolni úgy mint biotikus és abiotikus stressz. A biotikus stressz alatt az élőlények által okozott károsító hatást értjük. Növények esetében ilyenek a betegséget okozó vírusok, baktériumok, gombák, férgek, rovarok, magasabb rendű növényevő állatok, de a növények is hathatnak egymásra károsan: például parazitizmus esetén, de ide sorolható az egymás árnyékolása, vagy a tápanyagért folyó versengés a gyökérzónában. Az abiotikus stresszek négy nagy csoportba sorolhatóak, úgy mint hőmérséklet, ozmotikus, radiáció (besugárzás) és kémiai stresszhatások. A hömérsékleti hatások közé tartozik az alacsony (a fagypont közeli, ún. „chilling”, és a fagypont alatti) és magas hőmérséklet. Ozmotikus stresszcsoportba tartozik 
a vízhiány, árasztás és a szalinitás, azaz sóstressz. A radiáció stressz alá az összes elektromágneses sugárzás által okozott károsító hatást soroljuk. A kémiai stresszorok pedig a különböző kémiai anyagok, például szervetlen és szerves vegyületek (nehézfémek, fémek, növényvédőszerek, herbicidek). Fontos kiemelni azonban, hogy ezek a hatások a természetben ritkán jelentkeznek önmagukban. Például aszály esetén egyszerre van jelen a vízhiányból fakadó ozmotikus stressz és a magas hőmérséklet és ezekhez társulhat erős napfény besugárzás is. Dolgozatunkban a szárazság stresszel és a kémiai stresszcsoportba tartozó alumínium stresszel foglalkoztunk.

\subsubsection{Szárazságstressz}

A szárazságstressz az egyik legjelentősebb abiotikus stressz. Világviszonylatban elmondható, hogy az aszály okozza a legnagyobb mezőgazdasági károkat. Számos növényélettani folyamatot érint az időleges vagy tartós vízhiány. Emiatt fontos bizonyos fiziológiai paraméterek monitorozása a növények szelekciójánál a mezőgazdasági növénynemesítés során, hogy a toleráns egyedeket megtalálják. A legfontosabb élettani változások a turgor és ebböl kifolyólag a levélfelület csökkenése, a gyökérnövekedés fokozódása, a sztómák bezáródása. A szárazság azonban nem csak a termés mennyiségét, hanem annak minőségét is befolyásolja. Az össz nitrogén tartalom, fehérje mennyiség is csökken a szárazság stressznek kitett növényekben. A fehérjék a legfontosabb komponensei a gabonaszemeknek a keményítő mellett. Meghatározzák az étkezési búza minőségét. Elsősorban a genetikai háttér szabja meg ezt, de a környezeti faktorok is jelentősen befolyásolják (Barnabás és mtsai. 2008).

Vízhiányból fakadó stresszhatásról akkor beszélhetünk mikor a növény számára nem áll rendelkezésre megfelelő termodinamikai állapotban lévő víz. A szövetek és sejtek vízhiányának kialakulásának oka, hogy a növény párologtatása meghaladja a vízfelvételt. A vízhiány több féle stressznek is eleme lehet: például nem csak szárazság esetén alakul ki hanem sóstressz, vagy hidegstressz esetén is (Versalus és mtsai. 2006). Doktori munkánkban azonban csak a szárazság okozta vízhiány hatásaival foglalkoztunk. De meg kell említeni, hogy a sóstressz is nagyon hasonló fiziológiai változásokat okoz, és a nitrogén anyagcseréhez kapcsolódó enzimek mennyisége és müködése is a szárazságstressz alatt tapasztaltaknak megfelelően változik, a stresszválaszok sok ponton átfednek (Silveira és mtsai. 2001, Teixeria és Pereira 2007, Zhu és mtsai. 1998). 
A szárazságtürés mértékét nagyon nehéz meghatározni kizárólag csak szabadföldi körülmények között egy-egy termesztett növénynél, így a búzánál is. Ebből kifolyólag a vízhiányra adott stresszválaszokat olyan szántóföldi és laboratóriumi tesztvizsgálatokkal kell értékelni, amelyek az időjárástól függetlenül elvégezhetőek, gyorsak, kevéssé költségesek azonban megbízható eredményeket nyújtanak. A doktori munkánkban ezeket a szempontokat is szem elött tartottuk.

A szárazságstresszre adott válasz sokféle élettani paraméter változásában megnyilvánul a növényben. Ilyen a levélfelület kiterjedése, sztóma nyitottság, levélhőmérséklet változás, fotoszintetikus paraméterek változása, egyes hormonok szintjének változása (abszcizinsav, citokinin), vízpotenciál csökkenés. Bizonyos ozmoprotektáns molekulák felhalmozódását is megfigyelték a szárazság stressz alatt, mint például a fruktán, glicinbetain és a prolin (Goggin és Setter 2004, Gubiš és mtsai. 2007). A szárazsághoz való adaptációban nagy szerepe van a gyökérből érkező szignál molekuláknak, elsősorban az abszcizinsavnak. A növény a környezete vízellátottságát a gyökér vízzel telítettségi (turgor) állapotán keresztül érzékeli. A sejtfal feszülésének csökkenése több foszforilációs jelátviteli utat indít be, ami végül az ABS szintéziséhez vezet (Ali és mtsai. 1999, Cattivelli és mtsai. 2008, Zhang és mtsai. 2006). A nitrogén anyagcsere fontosabb enzimjeire is a szárazságnak jelentős kihatása van. Mind a nitrát reduktáz, mind a glutamin szintetáz aktivitása is megváltozik (Azcón és Tobar 1998).

\section{Szeneszcencia}

A szárazság leginkább szemmel látható hatása, hogy a növény öregedését (szeneszcenciáját) gyorsítja. A szeneszcencia egy genetikailag szabályozott, külső és belső faktorok által meghatározott folyamat. Ennek során megindul a fehérjék, lipidek, nukleinsavak és az összetett szénhidrátok degradációja. A leglátványosabb része a szeneszcenciának a klorofill degradációja (Smart 1994, Buchannan-Wollaston és mtsai. 2003). Az öregedő levelekben a fotoszintézis gátlódik, Rubisco és az elektron transzport lánc elemeinek aktivitása is lecsökken (Bertamini és Nedunchezhian 2002). A fotoszintetikus folyamatok megszünése egyértelmü összefüggésben áll a kloroplasztiszok degradálódásával, ennek pedig a citokinin szint csökkenése áll a hátterében (Ananieva és mtsai. 2008, Barneix 2007). A kloroplasztiszban először a tillakoid tünik el, majd pedig fotoszintetikus I és II rendszer fehérjéi és csak ezek után kezdődik a klorofill és karotinoidok lebontása (Ghosh és mtsai. 2001). 
A gabonaszemek tápanyag raktározási folyamata is korlátozódik, ugyanis a szemfeltöltődési periódus rövidül meg (Yang és Zhang 2005). A szemfeltöltődés az utolsó állapota a búza fejlődésének, ekkor történik meg a magon belül megtermékenyített sejtek tápanyagokkal történő ellátása. Ez szabja meg a mag végső tömegét és végső soron a betakarítható termés tömeget is. A szárazság hatása ekkor nyilvánul meg leginkább. A keményítő és fehérje anyagcsere is drasztikusan lecsökkent aktivitást mutat az öntözött növényekben mértekhez képest. Ennek közvetlen oka az endospermium sejtjeinek elégtelen száma (Barnabás és mtsai. 2008).

A növényekben a tápanyagok szállításának az irányát az ún. sink-source viszonyok határozzák meg. Egy adott szerv a kialakulása és kezdeti fejlődése esetén „sink”, azaz tápanyag felhasználó, de például a levél, miután elkezd fotoszintetikus folyamatokat működtetni, már „source” lesz, azaz már szénhidrát származékok forrása lesz. Egy adott szerv tehát lehet tápanyag felhasználó vagy szolgáltató és ezek a szerepek változnak a növény fejlődési szakaszaiban. Azt, hogy egy adott szerv pontosan milyen erős sink vagy source, sok tényező befolyásolja (tápanyagok mennyisége, hormon szintek, a szerv fejlettségi állapota), és több féle modellt alkottak már. A szeneszcencia folyamata is egy drasztikus változást okoz a sink-source viszonyokban (Marcelis 1996, Masclaux és mtsai. 2000). A növények öregedése több féle lehet, az egyszikü növényekre és így a búzára is a szekvenciális szeneszcencia a jellemző. Ennek során a növény alsó levelei hamarabb öregednek, mint a magasabb levélemeleten lévők. Az elöregedett levelekből a szerves és szervetlen tápanyagok és a víz a fiatalabb levelekbe és a kalászba szállítódik. A szén és nitrogén anyagcsere termékek transzportjában a glutamin szintetáz és az ADPglükóz pirofoszforiláz, mint a legfontosabb enzimek fontos szerepet játszanak, elsősorban az aminosav anyagcserén keresztül (Wiedemuth és mtsai. 2005). Az öregedési folyamatok során kialakuló szállítási irányokat minden esetben megfelelő hormonszintek szabályozzák. A szeneszcencia szabályozásában résztvevő legfontosabb hormonok a citokinin (egyszikü növényekben a zeatin), abszcizinsav és az etilén (Chandlee 2001). Az egyszikü növényekben a kialakuló termés képezi a legerősebb sink-et a virágzás utáni időszakban és emiatt ez a legkritikusabb időszak a szárazság stressz és termésmennyiség korrelációjának szempontjából (Kumar és mtsai. 2006). A nitrogén szerepe szorosan összekötődik a fotoszintézissel és az öregedési folyamatokkal is. Vizsgálatok kimutatták, hogy ha jó a nitrogén ellátottság a talajokban, az öregedési folyamatok késleltetődnek (Barneix 2007). Azonban azt is kimutatták, hogy megemelt széndioxid koncentráció esetén (650ppm) az 
öregedési folyamatok gyorsulnak. Feltételezhető, hogy a szénanyagcsere a fő szabályozója a szemfeltöltődésnek és a szénváz mennyisége szabályozza a nitrogén anyagcsere enzimeit is (Fangmeier és mtsai. 2000). A levél öregedése a levélfejlődés utolsó szakasza. Élettani, biokémiai, morfológiai és ultrastruktúrális változások sorozata követhető nyomon a növény levélszöveteiben, sejtjeiben és sejtorganellumaiban. Az öregedés gyorsulásával párhuzamosan azonban nem csökken a tápanyag transzport, hanem éppen gyorsul a levelekből a magok irányába (Barnabás és mtsai. 2008). A levelek zölden maradása (stay green) állapota nem mindig egyértelmü mutatója egy genotípus szárazság türésének, de mindenképpen elmondható, hogy a szárazság türő fajták rendelkeznek ezzel a tulajdonsággal. A levél asszimilációs állapotban maradása a virágzás után pozitív korrelációt mutat a nitrogén felvétellel és relokalizációval (Foulkes és mtsai. 2007).

\section{Rubisco szerepe a levélöregedésben}

A Rubisco (ribulóz-1,5-bifoszfát-karboxiláz/oxigenáz, EC 4.1.1.39) a C3-as fotoszintézist folytató növényekben a legnagyobb mennyiségben megtalálható fehérje. Az összfehérje tartalom 60-70\%-át is kiteheti. A növényben található nitrogén legnagyobb része itt található, búza esetében ez 20\% (Evans 1989, Makino és Osmond 1991). Az ilyen típusú fotoszintézist folytató növényekben a nitrogén anyagcsere szempontjából kiemelkedő jelentősége van a fotorespirációnak. A fotoszintézis egyik döntő lépése a $\mathrm{CO}_{2}$ fixálása, amely a fény-szakasz során termelt redukáló ágensekkel és energiával történik azáltal, hogy a ribulóz-bifoszfát karboxilálódik. Az enzimnek azonban, mint nevéből is

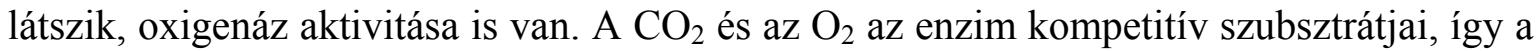
két reakció arányát az enzimet tartalmazó kompartmentben (kloroplasztisz) található szubsztrátok mennyisége szabja meg. A növények számára az oxigenáz aktivitás káros, mert a keletkező egyik termék, a foszfoglükonát, a szubsztráthoz képest oxidáltabb állapotú. Ezt a vegyületet csak bonyolult (számos enzim fenntartása, több sejtorganellum egymáshoz közeli elhelyezése) és energiaigényes folyamatok útján képes visszajuttatni a $\mathrm{CO}_{2}$ megkötés ciklusába. A szénváz visszajuttatására kialakult ciklusban (glikolát-kör), melynek lépései három különböző kompartmentben (kloroplasztisz, mitokondrium, peroxiszóma) zajlanak le, ATP és NADH felhasználása mellett $\mathrm{CO}_{2}$ és $\mathrm{NH}_{4}{ }^{+}$szabadul fel. A keletkező ammónium a kloroplasztiszban müködő GS/GOGAT úton keresztül képes reasszimilálódni. Az ammónia minél hamarabbi megkötése azért fontos, mert mint gáz halmazállapotú molekula könnyen képes kidiffundálni a sejtből és ez komoly veszteséget 
jelent, de az ammónia toxikus hatásait sem szabad figyelmen kívül hagyni (Portis és Parry 2007).

A Rubisco mint a legnagyobb mennyiségben előforduló fehérje a növényi fotoszintetizáló sejtekben, nemcsak az általa katalizált reakció miatt fontos, hanem mint nitrogén raktár is. Az öregedési folyamatokban a nitrogén transzportja meghatározó a növény termésérlelésének szempontjából. A virágzás utáni nitrogén felvétel és transzportja pozitívan korrelál a szárazság alatt a betakarítható termés mennyiségével (Foulkes és mtsai. 2007). Ezért fontos figyelemmel követni a Rubisco mennyiségi változásait a növény egyes részeiben. Az öregedő levelekben a lebontása úgynevezett RCB (Rubisco-containing body) sejtszervecskékben történik meg, amiben a citoszólikus GS1 izoenzim is jelen van. A Rubisco lebontása a kloroplasztiszon kívül történik, de annak degradációjával egy időben (Chiba és mtsai. 2003).

\subsubsection{Alumíniumstressz}

Az alumínium a Földön a legnagyobb mennyiségben megtalálható fém (Delhaize és Ryan 1995). A talaj szervetlen részének meghatározó hányadát alkotó fémhidroxidként amorf kolloid formában vannak jelen neutrális vagy gyengén savas kémhatás esetében. A talaj szervetlen alkotói között jelentős arányban szerepelnek az Al-szilikátok is, amelyek vízben való oldódáskor Al-hidroxiddá alakulnak, valamint $\mathrm{Al}^{3+}$ is kerül a talajoldatba. Semleges vagy lúgos kémhatás mellett ezeknek a szilikátoknak az oldhatósága igen alacsony, így az Al-hidroxidok és az Al-ionok talajoldatbeli koncentrációja nem jelentős. Azonban ha a talaj kémhatása $\mathrm{pH}=5$-re vagy az alá csökken, akkor rohamosan megnő ezeknek a vegyületeknek a mennyisége.

Az alumíniumion és az Al-hidroxidok különböző mértékben lehetnek toxikusak a növényekre, de mindenképpen elmondható, hogy jelenlétük minden esetben gátolja az arra érzékeny növények növekedését és fejlődését. A talaj savasodásának több oka is lehet. A sok csapadék vagy öntözés hatására végbemenő kilúgozódás $\left(\mathrm{CaCO}_{3}\right.$ kimosódása) okozhat pH csökkenést, de ebben az esetben a talaj pufferelő képessége is csökken, ami tovább fokozhatja a talaj savanyodását. A kén- és nitrogénoxidok nedves és száraz ülepedése (pl. savas esők) is a talaj pH-jának csökkenését okozzák. A talaj alapkőzetének kémiai tulajdonságai is befolyásolják annak kémhatását, valamint lehetséges alumínium tartalmát. 


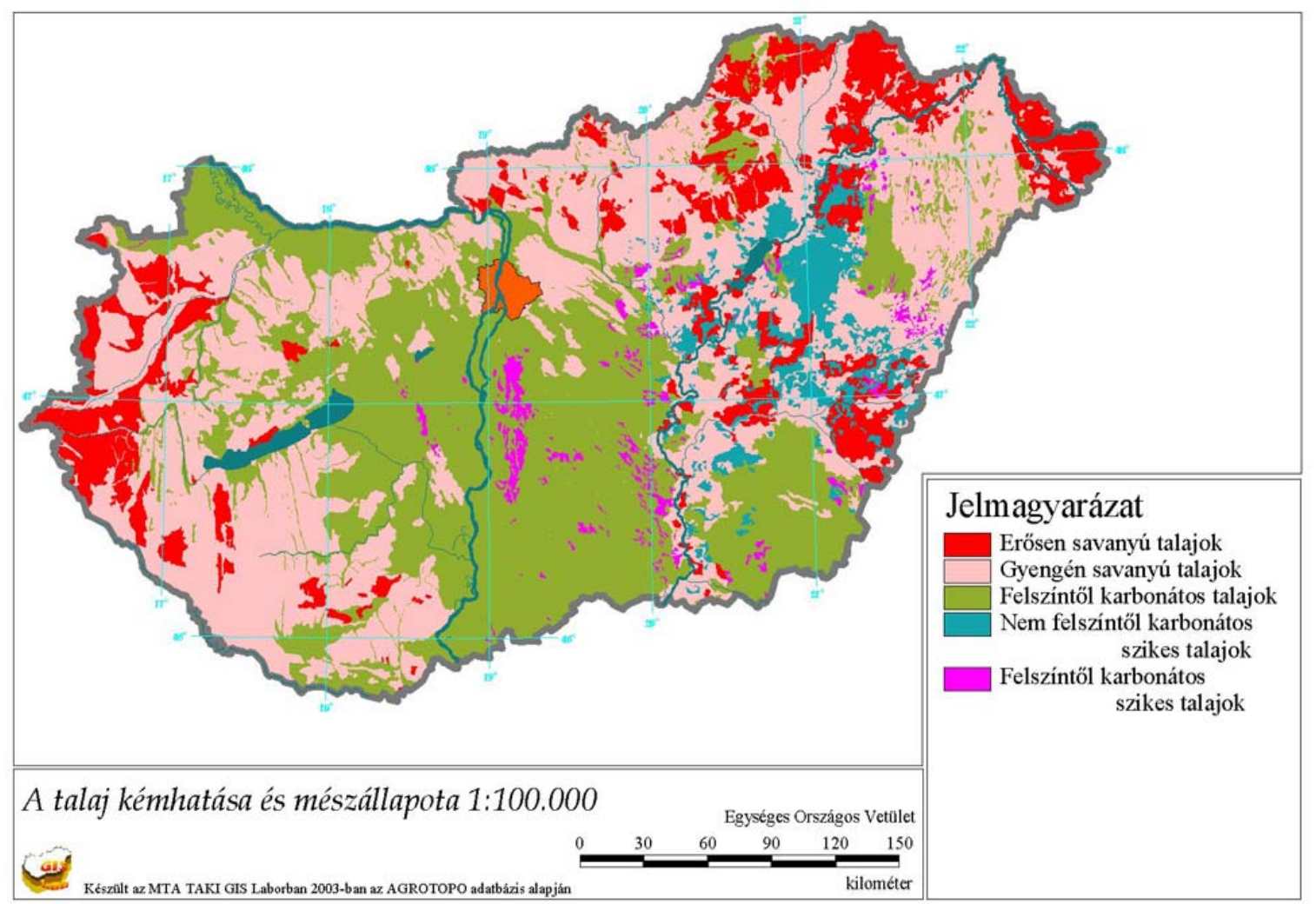

1. ábra: Magyarország talajainak kémhatás szerinti megoszlása.

Forrás: http://mta-taki.hu/hu/node/756 (2013.05.12)

A Föld mezőgazdasági művelés alatt álló területeinek jelentős részét érinti az elsavanyodás, és ez által az alumínium stressz. Elsősorban a trópusi éghajlaton fekvő országok érintettek ilyen szempontból. A világon a szántóföldek körülbelül 50\%-a, míg Magyarországon a mezőgazdaságba bevont területek körülbelül 25\%-a savanyú talaj. Hazánkban elsősorban a dél-dunántúli mezőgazdasági valamint az Északi-középhegység és a Tisza egyes vízrendszereihez tartozó területek savas kémhatásúak, emiatt ezeken a területeken problémát jelent a minőségi búzatermelés. A savas kémhatás fő oka természetesen a savanyú erdőtalajokból származtatható, azonban gyengén savanyú talajok már a mezőgazdaságba bevont területeken is előfordulnak. (1. ábra) 


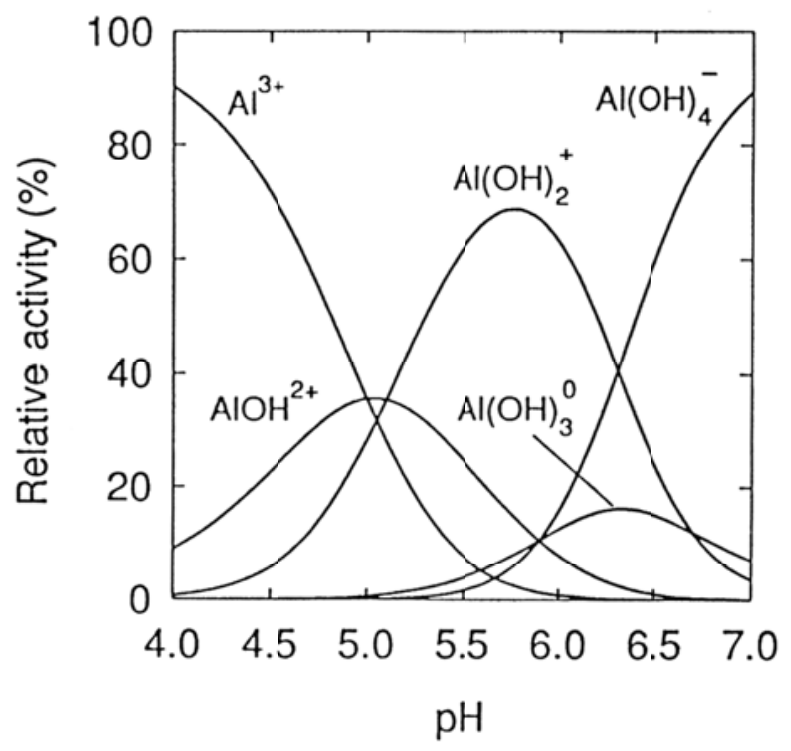

2. ábra: A mononukleáris Al(III) formák relativ aktivitásai, ha polinukleáris formák és OH- ionokon kívül más ligand nincs jelen (Parker és mtsai. 1989).

A rizoszféra savanyodása, és a velejáró $\mathrm{Al}^{3+}$ felszabadulás az egyik legjelentősebb stressz faktor a növények számára (Kiss 1989). Ezt a hatást képesek ellensúlyozni más kétértékü fémionok, például a $\mathrm{Mg}^{2+}$. In vitro körülmények között sikerült bizonyítani a magnéziumion protektív hatását (Kinraide és Parker 1987, Kiss 1989). Tehát megfelelő műtrágyázással megóvhatóak a növények az alumínium káros hatásaitól, azonban a helytelen mütrágyázás problémákat is okozhat, ugyanis vannak olyan vegyületek melyek elsavasíthatják a talajoldatot. Alumínium stressz hatására az adott területen az alumíniumra érzékeny növények növekedése gátlódik, ezáltal kisebb lesz a termés mennyiség, valamint annak minősége is romlik.

$\mathrm{Az}$ Al vizes oldatban két fő formában fordulhat elő: alumíniumion és alumíniumhidroxidok, de az Al-hidroxidok többféle formában is jelen lehetnek. Ezek mennyiségét és megoszlását elsősorban a talajoldat kémhatása szabja meg. (2. ábra)

Jól látható, hogy az alumíniumion relatív aktivitása $\mathrm{pH}=5$ allatt magas. Fontos figyelembe venni, hogy az egyes formák közötti átalakulás sebessége (elsősorban a polimerizáció) napokban vagy hetekben mérhető, az egyéb tényezőktől függően (például talajhőmérséklet). 
Az oldott Al-hidroxid formák alapvetően két csoportra oszthatók, mégpedig mononukleáris (egy központi $\mathrm{Al}^{3+}$ köré épülő komplexek) és polinukleáris (több alumíniumion körül kialakuló komplexek) formák. A mononukleáris formák a stabilabbak, ha az oldatbeli Al(III) koncentráció és az oldat pH-ja közt fennáll, hogy

\section{$\left[\mathrm{Al}^{3+}\right] /\left[\mathbf{H}^{+}\right] \leq \mathbf{1 0} \mathbf{8}^{8,8}$.}

Vagyis nagyobb töménységü Al oldatokat a polinukleáris formák megjelenésének veszélye nélkül csak nagyon alacsony pH-n lehet készíteni (Kinraide és Parker 1987). Komoly mértékben befolyásolják ezeken túl az oldatbeli $\mathrm{Al}(\mathrm{III})$ speciációját az oldat készítési körülményei, tárolása és és az készítés óta eltelt idő (Parker és mtsai. 1989).

A mononukleáris formák fitotoxicitására vonatkozó adatok gyakran ellentmondóak, azonban ezek az ellentmondások eltünnek, ha a kísérleti körülményeket a fenti tényezők függvényében vizsgáljuk. Ugyanis a mononukleáris formák bizonyos koncentráción és pH-n átalakulnak polinukleáris formákká. Ennek tükrében úgy tünik, hogy az egysziküek

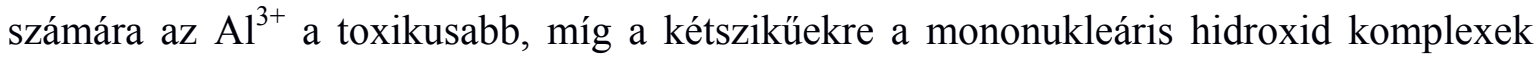
fejtenek ki erősebb toxikus hatást (Kinraide és Parker 1987 és 1990).

A polinukleáris formák közül kiemelkedő jelentőséggel bír az ún. $\mathrm{Al}_{13}$ $\left(\mathrm{AlO}_{4} \mathrm{Al}_{12}(\mathrm{OH})_{24}\left(\mathrm{H}_{2} \mathrm{O}\right)_{12}{ }^{7+}\right)$. Ennek fitotoxicitása nagyságrendekkel meghaladja bármely mononukleáris formáét (Kinraide 1990). Az Al(III) más ligandokkal alkotott komplexei nem toxikusak, ezen komplexek közül leggyakoribbak a szulfát- és fluoridkomplexek (Parker és mtsai. 1988), valamint egyes szerves savakkal (citrát, malát, oxalát) alkotott komplexek (Bartlett és Riego 1972, Ma és mtsai. 1998).

A talajból felszabaduló alumíniumra a legérzékenyebb növényi szerv a gyökér, azonbelül is a gyökércsúcs. Az alumínium hatására először a gyökérnövekedés lelassul vagy leáll, nagyobb alumínium koncentráció esetén pedig a gyökércsúcs elhal, ennek oka, hogy az alumínium gátolja a gyökércsúcsban lévő sejtek osztódását.

Hosszabb Al-kezelésnek kitett növényekben más elemek hiánya ( $\mathrm{Ca}, \mathrm{Mg}, \mathrm{P}$ ) indukálódik (Chang és mtsai. 1998). Ennek feltételezett oka, hogy a plazmalemmának fokozza a rigiditását az alumínium (Kiss 1989), emiatt pedig megváltozik a plazmalemma permeabilitása, és gátlódik más ionok $\left(\mathrm{Ca}^{2+}, \mathrm{Mg}^{2+}\right)$ felvétele is, ezért okozhatja az alumínium bizonyos fontos tápelemek hiányát. 
A sejtfalban, a plazmamembránban és a citoszolban is lehetnek alumíniumra érzékeny fehérjék (kallóz-szintáz, $\mathrm{H}^{+}$-ATP-áz), melyek müködése gátlódhat, ha alumínium kötődik hozzájuk (Kochian és mtsai. 2005). Ezen kívül megváltoztathatja a fehérjék konformációját ( $\alpha$-helix - $\beta$-sheet átmenetet okozhat), így azok aktivitását is képes megváltoztatni, valamint képes kötődni a DNS-hez is, amibe beépülve a transzkripció idő előtti terminációját okozhatja.

Tehát elmondható, hogy az alumínium elsősorban a gyökérre és a plazmamembránra gyakorolt hatása miatt jelentős anyagcserezavarokat okoz a növényekben. Ennek morfológiai megnyílvánulása a gyenge, satnya hajtás, sodródott levelek, valamint a hosszabb, magas koncentrációjú alumíniumstressz a növény pusztulását okozza.

A növények az $\mathrm{Al}^{3+}$ káros hatásait többféle mechanizmus útján igyekeznek elkerülni. Valószínünek látszik, hogy ezen mechanizmusok jelentősége növényfajonként (adott esetben fajtánként) eltérő, és nem létezik egyetlen univerzális mechanizmus a növény világban. Az is nyilvánvaló, hogy egyetlen növényben is több mechanizmus müködik együtt többé-kevésbé párhuzamosan, pl. a jelenlévő $\mathrm{Al}^{3+}$ mennyiségétől függően (Taylor 1991). Ezek feltehetőleg különböző gének szabályozása alatt állnak (Pellet és mtsai. 1997).

A növények tolerancia mechanizmusai két fö csoportba oszthatók: vannak, amelyek az alumíniumot a szimplaszton kívül tartják (kizárás), és vannak amelyek detoxifikálják azt.

A kizárási mechanizmusok közé tartozik a sejtfalban történő immobilizáció (kicsapás és beépítés a falanyagba), a plazmalemma alumíniummal szembeni permeabilitásának csökkentése (ioncsatornák szelektivitásának növelése), aktív Al-efflux, pH-barrier indukálása a rizoszférában $\left(\mathrm{Al}^{3+}\right.$ oldékonyságának csökkentése a gyökér közvetlen környezetében), foszfát exudáció ( $\mathrm{Al}^{3+}$ kicsapása) (Pellet és mtsai. 1997).

A sejten belüli detoxifikációnak is több módja lehetséges. Például a citoplazmába bejutott alumínium komplexálása (szerves savak, fehérjék, egyéb szerves ligandok) által (Ma és mtsai. 1998), de a detoxifikálás történhet a sejten kívül is a komplexképzők exudációjával (Miyasaka és mtsai. 1991, Yang és mtsai. 2000). Búza növényeknél kimutatták, hogy az Al-rezisztens genotípusú egyedek malát termelése fokozottabb (Basu és mtsai. 1994). A szerves komplexképző vegyületekkel kapcsolatban meg kell említeni a fitoextrakciót. A talajban található veszélyes fémionok növények általi eltávolítását nevezik fitoextraciónak. Az eljárások során felfedezték, hogy a komplexképző vegyületek 
hatékonyabbá teszik ezt a folyamatot. A mesterséges vegyületek közül a nitrilo-triecetsavat (NTA) és az etilén-diamin-tetraecetsavat (EDTA) nagyon hatékonynak találták (Quartacci és mtsai. 2005 és 2007). Ezenkívül a tolerancia további lehetőségei: az alumínium kompartmentalizálása a vakuolumba, Al-toleráns enzimek evolúciója, termelése, vagy az érzékeny enzimaktivitás fokozása.

Még megfigyelhető egy harmadik típusú védekezési forma is, ez az alumínium akkumuláció, de ezt eddig csak két faj esetében vizsgálták részletesebben. A tea (Camellia sinensis L.) és a hajdina (Fagopyrum esculentum Moench L.) is a levelében akkumulálja az alumíniumot. Hajdinánál ismert az $\mathrm{Al}^{3+}$ útja a gyökérből a levelekbe. Először is csatornafehérjéken keresztül jut át a plazmalemmán, majd a koncentráció grádienst követve jut el célhelyéig, ahol az oxálsav komplexálja, mint korábban már említettem ez a komplex egyáltalán nem toxikus. Azonban az oxálsav nem kerülhet a xilémbe, mivel kicsapná az ott jelenlévő kalciumot, ezért ott a citromsav képez komplexet az alumíniummal. A célszervben azonban ismételten az oxálsav komplexálja az $\mathrm{Al}^{3+}-\mathrm{t}$ (Ma és mtsai. 1998). Ismeretes még a hortenziák (Hydrangea sp.) virágszínének és annak alumínium tartalma közötti kapcsolat is, tehát ez a növény csoport is képes alumínium felhalmozásra, anélkül, hogy közben károsodna. Jól megfigyelhetö, hogy mint a legtöbb stresszreakciónál, itt is a védekezési folyamatok müködtetése meglehetősen energia igényes.

Az alumíniumnak azonban nem csak kifejezetten negatív hatásait írták le. Állati szervezetekben kimutatták már az alumínium enzimaktiváló hatását acetil-kolinészteráz esetében. Ennél az enzimnél a $\gamma$-periferiális láncok megváltoztatásával érte el $\mathrm{az} \mathrm{Al}^{3+} \mathrm{az}$ aktiváló hatást (Zatta és mtsai. 1994), tehát nem speciális helyre kötött be az alumínium, hanem csak megváltoztatta a fehérje konformációját. Arroyo-Serralta és munkatársai pedig MAP kináz szerű fehérje aktivitás növekedését mértek magas koncentrációjú (50 és 100 $\mu \mathrm{M}$ ) alumínium-klorid kezelés hatására kávé növények (Coffea arabica) sejtszuszpenziós kultúrájában (Arroyo-Serralta és mtsai. 2005).

Alumínium komplexek hatása a glutamin szintetázra (GS) nagyon eltérő lehet. Korábbi vizsgálatok rámutattak, hogy az alumínium komplexek lehetnek semlegesek a GS szempontjából, azaz se nem aktiválják, se nem gátolják azt. A GS szempontjából neutrális alumíniumot komplexáló anyagok, például a citrát és a malonát. Egyes Al-komplexek azonban aktiválják a GS-t, ilyen például a szintetikus NTA-val létrejött Al(III)NTA 
komplex. Ebben az esetekben kimutatták azt is, hogy az $\mathrm{Al}^{3+}$ nem kompetítora a $\mathrm{Mg}^{2+}$-nak, mivel a magnéziumra is szükség van az aktivitás megmaradásához (Kertész és mtsai. 2002).

\subsection{A növények szén és nitrogén anyagcseréjének kapcsolata}

A növények biomassza termelését, produktivitását és termés mennyiségét jelentős mértékben meghatározza a szervetlen nitrogén szerves szénláncokhoz való kötése. Ebben az anyagcsere folyamatban a legfontosabbak a következő enzimek: glutamin szintetáz (GS), glutamát szintetáz (GOGAT), glutamát dehidrogenáz (GDH), aszpartát aminotranszferáz (AspAT) és az aszparagin szintetáz (AS). A legfontosabb reakcióutak a 3. ábrán láthatóak. Néhány mondatban a szén-nitrogén metabolizmus enzimeit szeretném bemutatni.

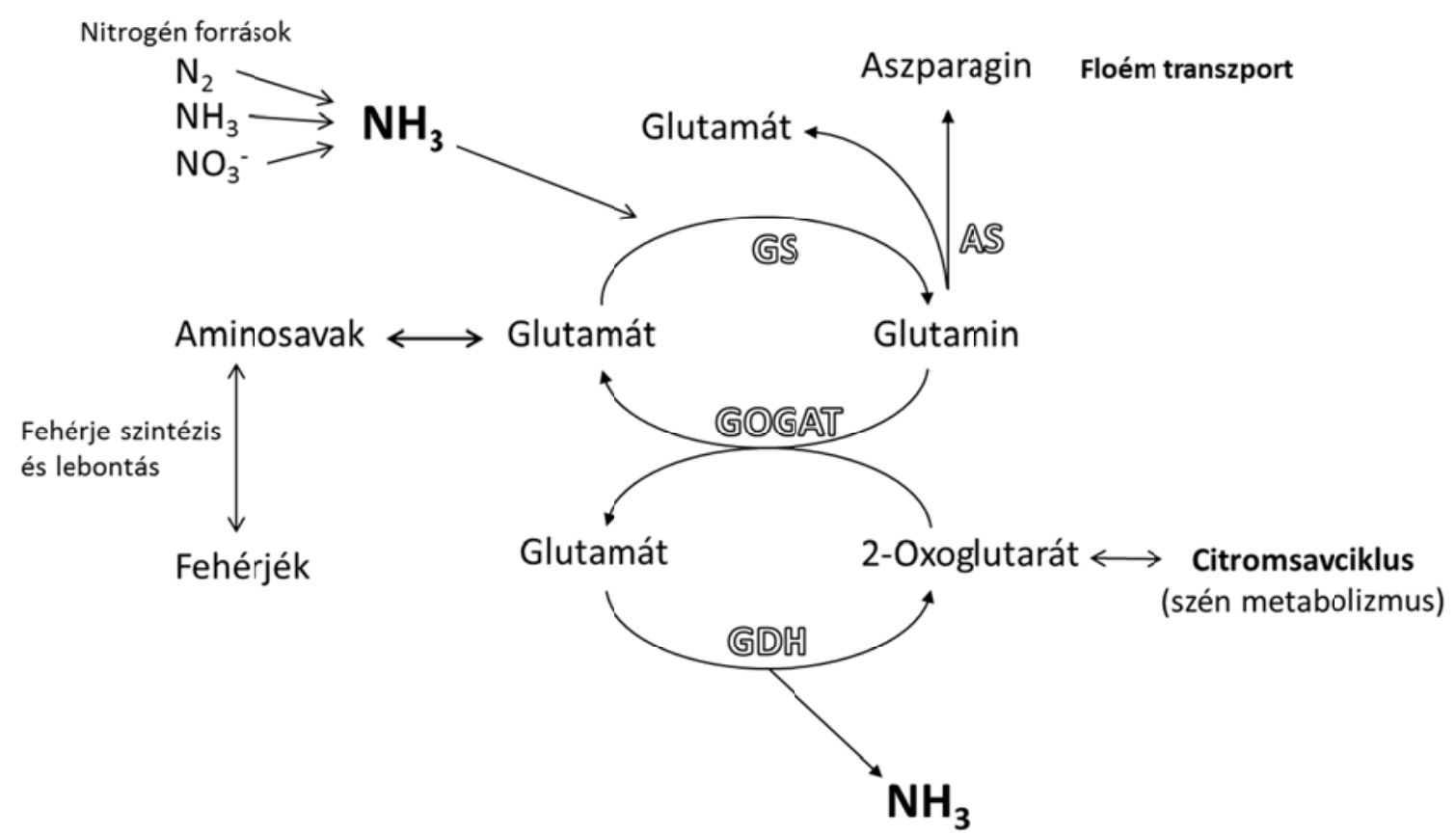

3. ábra: A szén és nitrogén anyagcserében fontos enzimatikus útvonallak. GS: glutamin szintetáz, AS aszparagin szintetáz, GOGAT: glutamát szintáz, GDH: glutamát dehidrogenáz (Miflin és Habash 2002 alapján). 
A szervetlen nitrogén forrás szénvázhoz kötését a későbbiekben részletesen bemutatásra kerülő glutamin szintetáz végzi. A glutamát szintetáz az aminosavak és a szén anyagcsere kapcsolatát szabályozza a 2-oxoglutaráton és a glutamáton keresztül. A 2oxoglutarát a citromsavciklus egyik fontos köztes terméke és így tud összekapcsolódni a GOGAT-on keresztül a szén és nitrogén anyagcsere. A glutamát dehidrogenáz (GDH) szerepe nagyon fontos a szerves nitrogénformákból történő ammónia felszabadításában. Ennek az enzimnek kiemelkedő szerepe van a szövetek alacsony $\mathrm{C} / \mathrm{N}$ arányának kialakulásában, ami elsősorban a szemfeltöltődés és a levelek szeneszcenciája során történik meg. Az aszpartát aminotranszferáz is a szén-nitrogén anyagcserét kapcsolja össze azáltal, hogy az aszpartáton lévő amino csoportot viszi át keto-glutarátra és így oxaloacetát és glutamát keletkezik. Az aszparagin szintetáz (AS) pedig a növény által a floémen keresztül könnyen transzportálható aszparaginra viszi át az aminocsoportot. Ez az enzimrendszer a talaj nitrogén ellátottságára reagál.

Magas nitrát koncentráció mellett a GS, GDH és nitrát reduktáz (az ábrán nincs feltüntetve, de a nitrátot alakítja át ammóniává) aktivitás is növekszik a gyökérben, búza növényekben (Bahrman és mtsai. 2005). De kétszikü növények közül a paradicsomban is a magas nitrát tartalom mellett detektálták a GS és a GDH mennyiségének növekedését (Scarpeci és mtsai. 2007). A levélöregedési folyamatokban a nitrogén mobilizációjában kimutatták az AS szerepét, a szenszcencia során megemelkedik az aszparagin szintáz aktivitása és a glutamin szintjével együtt az aszparagin mennyisége is növekszik (HerreraRodrígez és mtsai. 2005).

A növényekben ezek az enzimek a levélben fényszabályzás alatt állnak. A GS és GOGAT génexpresszióját pozitívan, míg az AS és GDH génkifejeződésére negatívan befolyásolja a fény a fitokróm fotoreceptorokon keresztül. Metabolit szabályzást is felfedeztek ebben a rendszerben. A szacharóz szint emelésével ugyanazt tapasztalták, mint a fényszabályzás esetében, ez alapján feltételezik, hogy a fotoszintetikus aktivitás is meghatározó a nitrogén anyagcsere szabályzásában. A sejten belüli $\mathrm{C} / \mathrm{N}$ arányt is meghatározónak találták a génkifejeződések szempontjából. Ezek is azt mutatják, hogy a szén és nitrogén transzport nem csak kinetikai és szubsztrát/termék kapcsolataiban, hanem szabályozásában is kapcsolatban áll (Lam és mtsai. 1996, Miflin és Habash 2002). Ezeken kívül még a glutamát szintjét is meghatározónak találták a nitrogén anyagcsere sebességében. Pozitív korreláció van a szénváz és a nitrogén asszimiláció között (Foyer és mtsai. 2003). Érdemes megemlíteni a nitrogén és szén anyagcsere kapcsán azt is, hogy 
Zheng-xun és munkatársai leírták, hogy rizsben a glutamin szintetáz aktivitásbeli eltérései meghatározták a szemtermés főzési és emészthetőségi minőségét (Zheng-xun és mtsai. 2007).

\subsection{Glutamin szintetáz}

Elmondható, hogy a nitrogén anyagcsere a mezőgazdasági termelés szempontjából a legmeghatározóbb, ugyanis a fotoszintézis, az aminosav és fehérje bioszintézisen keresztül befolyásolja a termés mennyiségek alakulását (Lawlor 2002). A virágzás és a szemfeltöltődési időszak alatti nitrogén ellátottság pedig szintén a biztosabb terméshozam mutatója (Barbottin és mtsai. 2005). Az általunk vizsgált enzim, a glutamin szintetáz, a nitrogén metabolizmus egyik kulcsenzime, mely nem csupán növényekben fordul elö, hanem megtalálható a gombáknál, az állatvilágban, sőt - bár kissé más formában - a prokarióták csoportjaiban is. Az enzim EC (Enzyme Commission number) száma 6.3.1.2, ami azt jelöli, hogy az olyan típusú ligázok csoportjába tartozó enzim, ami a nitrogén-szén kötés oldásáért és/vagy létrehozásáért felelős. Az általa katalizált reakcióban ATP felhasználásával magnéziumion jelenlétében ammónum-iont köt glutamáthoz és ennek eredményeképpen glutamin, ADP és egy $\mathrm{P}_{\mathrm{i}}$ keletkezik.

A GS-nek több fontos szerepe is van a növények életében: egyik feladata a felvett nitrogén, ami általában nitrát, amit a növény a nitrit- és nitrát-reduktáz segítségével redukál ammóniává, beépítése szerves vegyületekbe (glutamin), másik pedig a fotorespiráció és egyéb fehérje degradációval járó folyamatok (öregedési folyamatok, stressz folyamatok) során keletkező $\mathrm{NH}_{4}^{+}$reasszimilációja. A két szerep jelentősége faj- és fejlődési állapot függvénye. Ugyanis az intenzíven fotoszintetizáló $\mathrm{C}_{3}$ típusú növényekben a fotorespiráció során felszabaduló ammónia mennyisége elérheti az elsődleges nitrogén-asszimilációból származónak akár a 20-szorosát is (Canvin 1990). A GS-nek ezeken kívül az öregedési (szeneszcencia) folyamatok során végbemenő nitrogén retranszlokációban is fontos szerepe van. A növény öregedő szerveiből képes kimenteni a már beépített anyagokat. A GS segítségével hozzáférhetővé válik a redukált állapotú nitrogén, amelynek redukciójához a növény sok energiát használt fel, így viszont sok energiát tud megtakarítani. A fehérjéket proteázok bontják le, a felszabaduló, a sejtre egyébként toxikus hatással lévő ammóniumiont pedig a GS viszi be a glutaminba, amelynek így detoxikáló szerepe is van. A keletkezett glutamin ezután újbóli felhasználási helyére szállítódik, ahol más aminosavak, majd pedig fehérjék felépítésére fordítódik. 
Látható, hogy a glutamin szintetáz mennyire szerteágazóan vesz részt az egyes élettani folyamatokban, ezért vizsgálata, állapotának és aktivitásának meghatározása segít vizsgálni a növényben lezajló folyamatokat. A GS aktivitásának meghatározásával nyomon követhető, hogy egy adott stresszhelyzetre, hogyan reagál a növény, milyen túlélési stratégiát választ. Továbbá müködésének (aktiválódás, inaktiválódás) megértése választ adhat arra, miképpen reagál a növény a különböző környezeti hatásokra.

A korábban említett fiziológiás reakciókon túl a GS katalizál még két másik in vitro lejátszódó reakciót is, ahol nem az ammónia az enzim szubsztrátja hanem a hidroxilamin:

Szintetáz reakció:

$\mathrm{NH}_{2} \mathrm{OH}+$ L-glutamát + ATP $\quad \underset{\text { Me2+ }}{\longrightarrow} \gamma$-glutamil-monohidroxamát $+\mathrm{ADP}+\mathrm{P}_{\mathrm{i}}$

Transzferáz reakció:

$\mathrm{NH}_{2} \mathrm{OH}+$ glutamin $+\mathrm{ATP} \quad \stackrel{\mathrm{Me} 2+, \mathrm{ADP}, \mathrm{Pi}}{ } \gamma$-glutamil-monohidroxamát $+\mathrm{NH}_{3}$

A transzferáz reakció fiziológiai jelentősége nem ismeretes, így a révén nyert aktivitásbecslés fenntartással kezelendő. A szintetáz reakció viszont felfogható a fiziológiás reakció olyan esetének, amikor az ammóniát hidroxilaminnal helyettesítjük, és így az enzim valódi aktivitását tudjuk mérni, ha detektálni tudjuk a $\gamma$-glutamilmonohidroxamát mennyiségét (Lea 1985, Layzell 1990).

A prokarióta GS mind szekvenciálisan, mind pedig másod- és harmadlagos és negyedleges szerkezet tekintetében jól ismert, tisztázták az aktív centrum finomszerkezetét, valamint pontos müködését (Eisenberg és mtsai. 2000). Ismerjük a háromdimenziós szerkezetét is (4. ábra). Azonban a különböző GS-ok gén szekvencia adatai azt mutatják, hogy az enzim kulcsfontosságú részei (pl. az aktív centrum) evolúciósan igen nagyfokú konzerváltságot mutat. Az eukarióta és a prokarióta GS között a legnagyobb a különbség, ez főképp abban nyilvánul meg, hogy a prokarióta GS hosszabb mintegy száz aminosavval. Ennek oka, hogy a prokarióta GS adeniláció által is szabályzódik, és az adenilációért felelős szakaszok a C-terminális végen találhatók, ez a rész az eukarióta GS-ből hiányzik. 

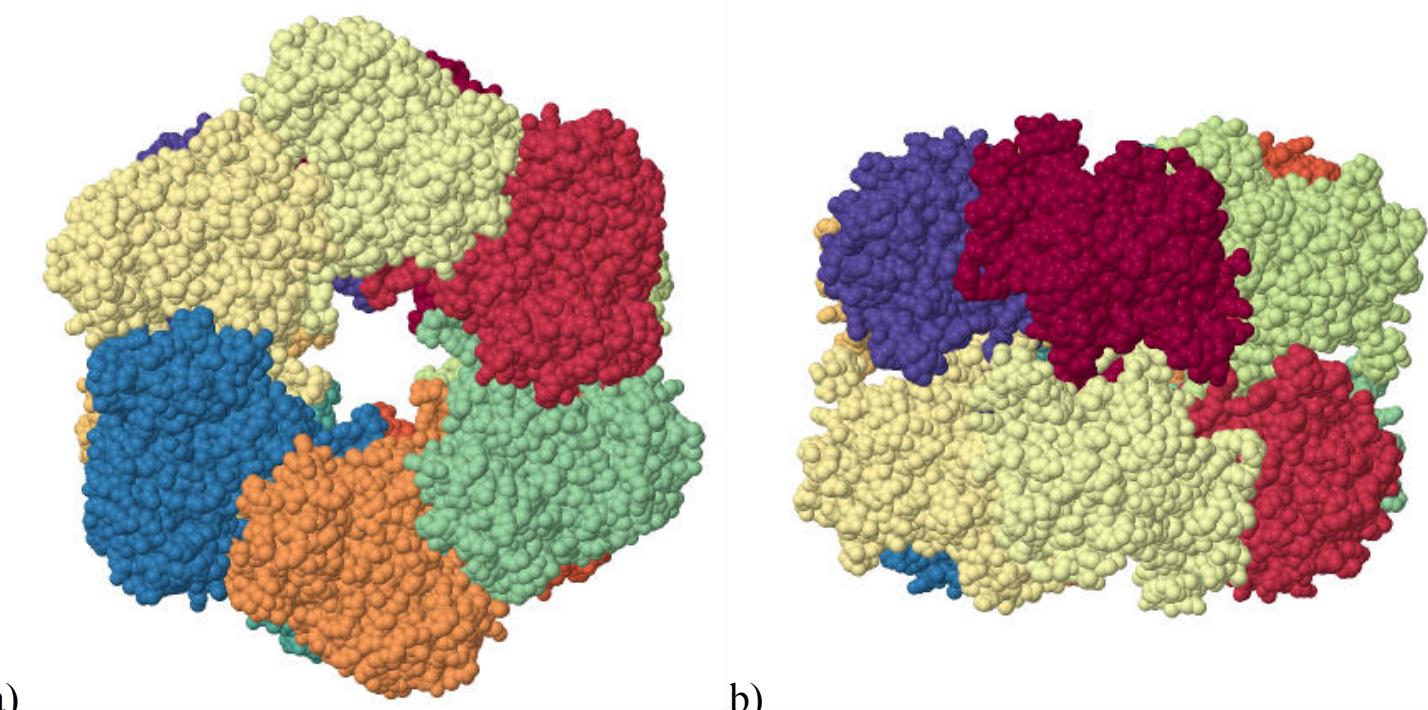

a)

b)

4. ábra: A prokarióta glutamin szintetáz holoenzim három dimenziós ábrázolása a Jmol webes alkalmazással. Az egyes alegységek külön színnel vannak megjelölve.

a) felülnézet; b) oldalnézet

Forrás:

http://www.rcsb.org/pdb/explore/jmol.do? structureId $=2 G L S \& o p t=3 \&$ bionumber $=1$ (2013. 05. 11)

Az eukarióta GS nyolc alegységből épül fel (a prokarióta tizenkettő alegységből áll), ezek az alegységek négy-négy alegységből álló gyürüt alkotnak, ezek a gyűrűk egymásra fekszenek a holoenzimben. A teljes enzim nyolc aktív centrumot tartalmaz, bár ez még ma is viták tárgyát képezi, mivel gyakorlatilag nem lenne lehetséges térkitöltési szempontok miatt. A gyürük és az alegységek összetartásában hidrogénkötések, hidrofób kölcsönhatások, valamint bivalens kationok játszanak szerepet. Az eukarióta GS holoenzim molekula tömege 372 kDa (patkány máj GS) és 520 kDa (borsó GS) között mozog az eddig vizsgált élőlényekben (Eisenberg és mtsai. 2000).

Mivel az aktív centrum szekvenciája és szerkezete konzervált az élővilágban, ezt az információt az eukarióta enzimekre is érvényesnek fogadhatjuk el. Minden aktív centrum középpontjában két bivalens kation kötőhely található, $n 1$ és $n 2$. Az $n 1$ helyre kötődő fémion az alegységek összetartásáért és a glutaminsav kötéséért felelős, az $n 2$ helyre kötődő fémion pedig a foszforil transzferben vesz részt, tehát ez fémkötőhely is elengedhetetlen az aktivitáshoz (Eisenberg és mtsai. 2000). Fiziológiás körülmények között a növényekben mindkét helyre $\mathrm{Mg}^{2+}$ kötődik, de rizs és csillagfürt esetében $\mathrm{Fe}, \mathrm{Zn}$ vagy Mn is kötődhet ezekre a helyekre (Hirel és Gadal 1980, Chen és Kennedy 1985). 
Heterotróf és prokarióta szervezetek esetében eddig csak $\mathrm{Mg}^{2+}-\mathrm{t}$ és $\mathrm{Mn}^{2+}$-t figyeltek meg az aktív centrumban. Valószínüleg fiziológiásan a $\mathrm{Mg}^{2+}$ fordul elő, mert bár a fém kötőhelyek mangán iránti affinitása jóval nagyobb, a mangán bekötődése az aktív centrumba aktivitás csökkenést okoz (Eisenberg és mtsai. 2000).

A glutamin szintetáz a magasabbrendü növényekben homo oktamer felépítésü, és a monomerek asszociációjához, az enzim stabilitásához bivalens kationokat igényel mM-os koncentrációban (Vance and Griffith 1990). Az enzim müködéséhez is igényli a bivalens kationok jelenlétét, ugyanis az egyik szubsztrátja az ATP, amely a kétértékü kation komplexeként kötődik az enzimhez (Layzell 1990). Tehát az eukarióta enzimnél tapasztaltak is a prokarióta enzimmel való nagyfokú müködési hasonlóságot támasztják alá.

Fiziológiás megfontolásokból (a sejtekben a $\mathrm{Mg}^{2+}$ koncentrációja éri el az enzim müködéséhez a szükséges szintet, és képes tartósan fenn maradni) a $\mathrm{Mg}^{2+}$-ot alkalmazzák az enzim in vitro aktiválásához, aktivitás-meghatározásához. Egyben a $\mathrm{Mg}^{2+}$ a legerősebb aktivátora a GS-nek, bár egyes alumínium komplexek a magnéziummal együtt müködve tovább képesek növelni a GS aktivitását (Kertész és mtsai. 2002).

A glutamin szintetáz izoenzim gének átírásával kapcsolatban meg kell említeni, hogy szervenként, szövetenként eltérő. Kódolásukért különálló gének felelősek. Bizonyos külső faktorok jelentősen befolyásolják, a legjelentősebb befolyásoló faktorok a fény, a szénhidrát és a nitrogén források. Arabidopsisban a GLN2 gén expressziója és a sejten belül a glutamin szint is emelkedett fény hatására. Szintén arabidopsisban a fitokróm rendszerrel való kapcsolatot találtak. Az egyes izoenzimek génexpressziója felődési állapotonként is eltérő, csak bizonyos fejlődési szakaszokban aktívak egyes GS gének (Swarup és mtsai. 1990). Fontos kiemelni, hogy a génexpresszió indukciója nem mindig okoz mérhető enzimaktivitás növekedést, tehát poszt transzlációs szabályzása is van a glutamin szintetáznak (Lam és mtsai. 1996, Miflin és Habash 2002). Az mindenképpen elmondható, hogy foszforiláción keresztül szabályzódik az enzim, a foszforilált enzim a sejten belüli félélet ideje hosszabb mint a nem foszforilált formának. Védve van a fehérje degradációtól. Az eddigi vizsgálataink szerint a foszforilálódott enzim 14-3-3 fehérjék jelenlétében megnövekedett aktivitást mutat. De ezeket a jelenségeket még csak a citoszólikus GS izoenzimre sikerült igazolni (Finnemann és Schjoegerring 2000). Eddigi kutatásaink alapján feltételezzük, hogy a GS2-nek szubsztrát által közvetlenül szabályozott az enzimaktivitása. A nitrogén jelenléte növeli a génexpressziót és így a fehérje 
mennyiségét is a hajtásban, gyökérben, azonban pillangós virágú növényekben, a modell növény lucerna (Medicago sp.), a nitrogén megkötést végző gümőkben nincs reakció a nitrogén ellátottság változására. Elmondható hogy a talajban jelenlévő nitrát jobban indukálja a GS enzimek transzkripcióját mint az ammónia. A gyökérben mindig hamarabb történik a gén átírás indukciója (Zozaya-Hinchliffe és mtsai. 2005, Zhao és Shi 2006).

A növényi GS számos izoenzimmel rendelkezik. Ezek megjelenése fajtól és fejlődési állapottól (szerv kora, noduláció, stb) függ. A hexaploid búzában (Triticum aestivum L.) három izoenzim található, míg az egyszerübb genom felépítésü rizsben (Oryza sativa L.) hat. A búzának eddig három GS izoenzimje ismert. A gyökérsejtek citoszoljában lokalizálódó $\mathrm{GS}_{\mathrm{R}}$, valamint a hajtásban található citoszólikus GS1 és plasztidikus GS2 (McNally és Hirel 1983). A GS1 és $\mathrm{GS}_{\mathrm{R}}$ formák között a különbség elhanyagolható, ezért legtöbbször nem is különböztetik meg őket (például PAGE fehérje elválasztás során azonos helyre futnak, azaz felületi töltésük megegyezik). A GS2 azonban jelentősen eltér az előző kettő izoenzimtől, mind molekula tömegben, mind felületi töltés szempontjából. A nitrogénkötő pillangósvirágú növények gümőiben a glutamin szintetáz és a glutamát szintetáz enzimek pedig mind szabályzás mind pedig felépítés szempontjából eltérnek a gyökérben és a hajtásban található izoenzimektől (Chen és Cullimore 1989).

A hajtásbeli formák közül a GS2 a domináns, mind mennyiségileg, mind pedig az aktivitást tekintve, főleg ennek az izoenzimnek tulajdonítják a fotorespiratorikus ammónia megkötését, és mivel a kloroplasztiszban történik meg a nitrit ammóniává történő redukálása, így érthető miért nagyobb a GS2 aktivitása, mint a GS1-é a hajtásban. Etiolált majd pedig fénynek kitett levelekben elsősorban a GS2 aktivitása növekedik meg, $\mathrm{C}_{4}$ és CAM típusú növényeknél azonban a GS1 a domináns izoforma (Vance és Griffith 1990). A $\mathrm{GS}_{\mathrm{R}}$ izoenzimnek a gyökérszőrök által a talajoldatból felvett ammónia beépítésében van szerepe, így nem maga az ammónia transzportálódik a floémen keresztül a hajtásban, hanem már a szerveskötésbe bevitt nitrogén. Erre azért van szükség, mert az ammónia gázhalmazállapotú, illékony vegyület, könnyen átdiffundál a sejtmembránon, ezért szabad formában nagyon nehezen transzportálható.

Az eddigiek alapján látható hogy a GS a növény élete szempontjából kulcs fontosságú. Glutamin szintetáz mutánsokat emiatt nem is sokat írtak le, illetve csak egyes izoenzimekben hiányos növényeket tudtak vizsgálni. Tabuchi és munkatársai az egyik GS1 izoenzimre knockout mutáns rizsben megfigyelték, hogy a növények méretben is kisebbek 
voltak és a szemfeltöltődésben is elmaradt a vadtípusok mellett. És hiába rendelkezik a rizs több GS1 izoenzimmel még se volt képes kompenzálni ennek az egynek a hiányát, ami a GS1;1 volt (Tabuchi és mtsai. 2005). A GS1-et overexpresszáló növényekben pedig egyértelmüen a szervek nitrogéntartalmának növekedését írták le. A biomassza 17\%-kal több, mint a kontroll esetben, a nitrogén tartalom pedig 54\%-kal volt több friss tömegre vonatkoztatva (Fei és mtsai. 2006). 


\section{Célkitüzés}

A növények nitrogén anyagcseréje meghatározó a termöképesség és növekedés szempontjából. A glutamin szintetáz kulcsszerepet játszik a növények nitrogén metabolizmusában, fontos szerepe van a növekedési és öregedési folyamatokban egyaránt. Mivel a környezeti faktorok jelentősen képesek megváltoztatni a növény fiziológiai állapotát, ezért fontos ezzel az enzimmel alapkutatási szinten is foglalkozni. Kísérleteink célja az volt, hogy búza növények (Triticum aestivum L.) különböző genotípusaiban megvizsgáljuk szárazság- és alumíniumstressz alatt a glutamin szintetáz mennyiségi, aktivitási és enzimkinetikai változásait.

Vízhiány esetében a növény öregedési folyamatai felgyorsulnak. Az egyéves egyszikü növényekre általában a szekvenciális öregedés jellemző optimális körülmények között. Azaz a levelek a gyökér felöl a termés felé haladva, a hormonok által szabályozott „sink-source” viszonyoknak megfelelően, fokozatosan lépnek be az öregedési folyamatba. Kísérleteinkben több búza genotípus öregedését követjük figyelemmel öntözött és vízhiányos körülmények között. Mivel a búza terméshozama a virágzáskor a legérzékenyebb a környezeti hatásokra, ezért úgy állítottuk be a kísérleti rendszert, hogy az antéziskor kezdtük meg a szárazság stressz előidézését ellenőrzött körülményeket biztosító üvegházban. A növényekben végbe menő változásokat az öregedő levelekből vett minták vizsgálatával követtük nyomon. Mértük a levelek fehérje tartalmát, natív poliakrilamid gélelektroforézissel a Rubisco tartalmat vizsgáltuk. A glutamin szintetáz aktivitását is mértük illetve western blot analízissel az izoenzimek arányát is meghatároztuk.

A GS bivalens fémionokat kötő enzim, érzékeny a fémstresszre, ezért is érdemes vizsgálni a GS és a fémionok kapcsolatát. Az Al(III) eddig ismert kémiai természete (vizes oldatokban tapasztalható bonyolult és nehezen reprodukálható viselkedés) miatt viszonylag

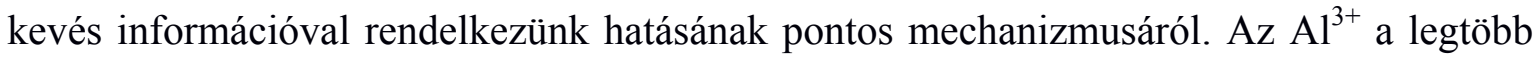
esetben toxikus az élőlényekre. A legtöbb növény müködtet a szervezetében valamilyen rendszert, amivel el tudja kerülni az alumínium káros hatásait. Az egyik ilyen stratégia az alumínium komplexbe vonása különböző szerves savakkal. Egyes Al-komplexek in vitro aktiválják a GS-t. Az Al(III)NTA komplex az egyik legjobb ilyen aktivátora a GS-nek. Munkánk célja megvizsgálni, hogy az Al(III)NTA komplex milyen módon növeli a GS 
aktivitását, ennek érdekében kinetikai vizsgálatokat végeztünk. Az elsődleges cél annak kiderítése, hogy a GS képes-e alumíniumot kötni. In vitro körülmények között szeretnénk kimutatni magnézium és alumínium kötődését a GS-hez, valamint megtudni, hogy milyen kapcsolat van az alumínium és magnézium között a GS-hez kötődés képességében. Ezen kérdések megválaszolásához poliakrilamid gélelektroforézist, western blot analízist, spektrofotometriás enzimaktivitás mérést és ICP-AES technikát vettünk igénybe.

A dolgozatomban a következő kérdésekre kerestünk választ:

a) Szárazságstressz indukált levél szeneszcencia során, hogy változnak a ,sinksource" viszonyok, és az élettani stratégiák különböző genotípusú búza növényekben?

b) Milyen kapcsolat van a vízhiány okozta stressz alatt a búza növény szén és nitrogén anyagcseréje között?

c) Hogy változik a glutamin szintetáz aktivitása mennyisége és az izoenzimek aránya szárazságstressz hatására búza növényekben?

d) Milyen hatással van a savas növekedési közegben az alumínium a fiatal búza fejlődésére?

e) Van-e az alumíniumnak közvetlen hatása a glutamin szintetázra?

f) Milyen hatása van az Al(III)NTA szerves sav komplexnek a glutamin szintetázra? 


\section{Anyagok és módszerek}

\subsection{Növényi anyag}

Az általunk vizsgált búzafajták a következők voltak a szárazságstressz hatásainak vizsgálatához:

T. aestivum L. cv. Cappelle Desprez - intenzív búzatermesztésben magas hozamot hozó, szárazság-érzékeny, francia, őszi búzafajta. Forgalomba hozatalának éve: 1946. Forrás: Dr. Cseuz László, Gabonakutató Nonprofit Kft., Szeged.

Triticum aestivum L. cv. Mv Emese - minőségi termést hozó, szárazságtürő magyarországi, Martonvásáron nemesített, őszi búzafajta. Elismerés éve: 2000.

T. aestivum L. cv. GK Élet - Intenzív típusú, rekordtermésekre képes, korai érésű, tar kalászú, közepes szárazságtürésű, őszi búzafajta. Elismerés éve: 1996.

T. aestivum L. cv. Kharchia - indiából származó, fakultatív tájfajta. Forrás: Prof. Dr. Erdei László, Szegedi Tudományegyetem, Növénybiológiai Tanszék.

T. aestivum L. cv. Kobomugi - Belső-Ázsiából származó, fakultatív tavaszi tájfajta. Forrás: Prof. Dr. Erdei László, Szegedi Tudományegyetem, Növénybiológiai Tanszék.

T. aestivum L. cv. Plainsman V - közepes hozamú, minőségi termést hozó, szárazságtűrő, észak-amerikai, őszi búzafajta. Forgalomba hozatalának éve: 1974. Forrás: Dr. Cseuz László, Gabonakutató Nonprofit Kft., Szeged.

Az alumíniumstressz vizsgálatához alkalmazott búzafajta:

T. aestivum L. cv. Jubilejnaja-50 - Kiváló adaptálódó képességgel rendelkező, középérésü, kiváló minőségü, extenzív típusú fajta. Még a Szovjetunióban, ukrajnai területen nemesített fajta. Elismerés éve: 1970. Forrás: Dr. Bóna Lajos, Gabonakutató Nonprofit Kft., Szeged. 


\subsection{Növénynevelés}

\subsubsection{Szárazságstressz vizsgálathoz alkalmazott növénynevelés}

A kalászoló növények neveléséhez használt talaj Terra típusú virágföld és marosi homok 50-50\%-os elegye volt. A fekete polietilén zacskók 100\%-os nedvességtartalom esetén $2000 \mathrm{~g}$ talajkeverék befogadására voltak alkalmasak, aminek a tömege légszáraz állapotban $1400 \mathrm{~g}$. A kontroll és stresszelt növények öntözésének szétválasztása a kalászhasban állapot kezdetekor történt, ez a virágzás előtti 4-6. nap. A kontroll növényeket a talaj $100 \%$-os vízkapacitásának 60\%-ra, a stresszelt növényeket a 25\%-ra öntöztük vissza a talaj tömege alapján 2-3 naponta. $300 \mu \mathrm{mol} \mathrm{m} \mathrm{m}^{-2} \mathrm{~s}^{-1}$ fényintenzitáson, 12/12 óra fény/sötét megvilágítási periódussal, $25 / 20{ }^{\circ} \mathrm{C}$ nappali/éjszakai hőmérsékleten, $55-60 \%$ relatív páratartalom mellett neveltük a növényeket üvegházban. (5. ábra) A mintavételi időpont az anthézis utáni (DPA) 9. napon történt. Ekkor a növények leveleit levágtuk és a fehérje kivonásig $-80{ }^{\circ} \mathrm{C}$-on tároltuk. Elsősorban a zászlós levelet és az az alatti levelet használtuk, de a Plainsman V és Cappelle Desprez fajtánál a felső négy levélszintből vettünk mintákat (Nagy és mtsai. 2013).

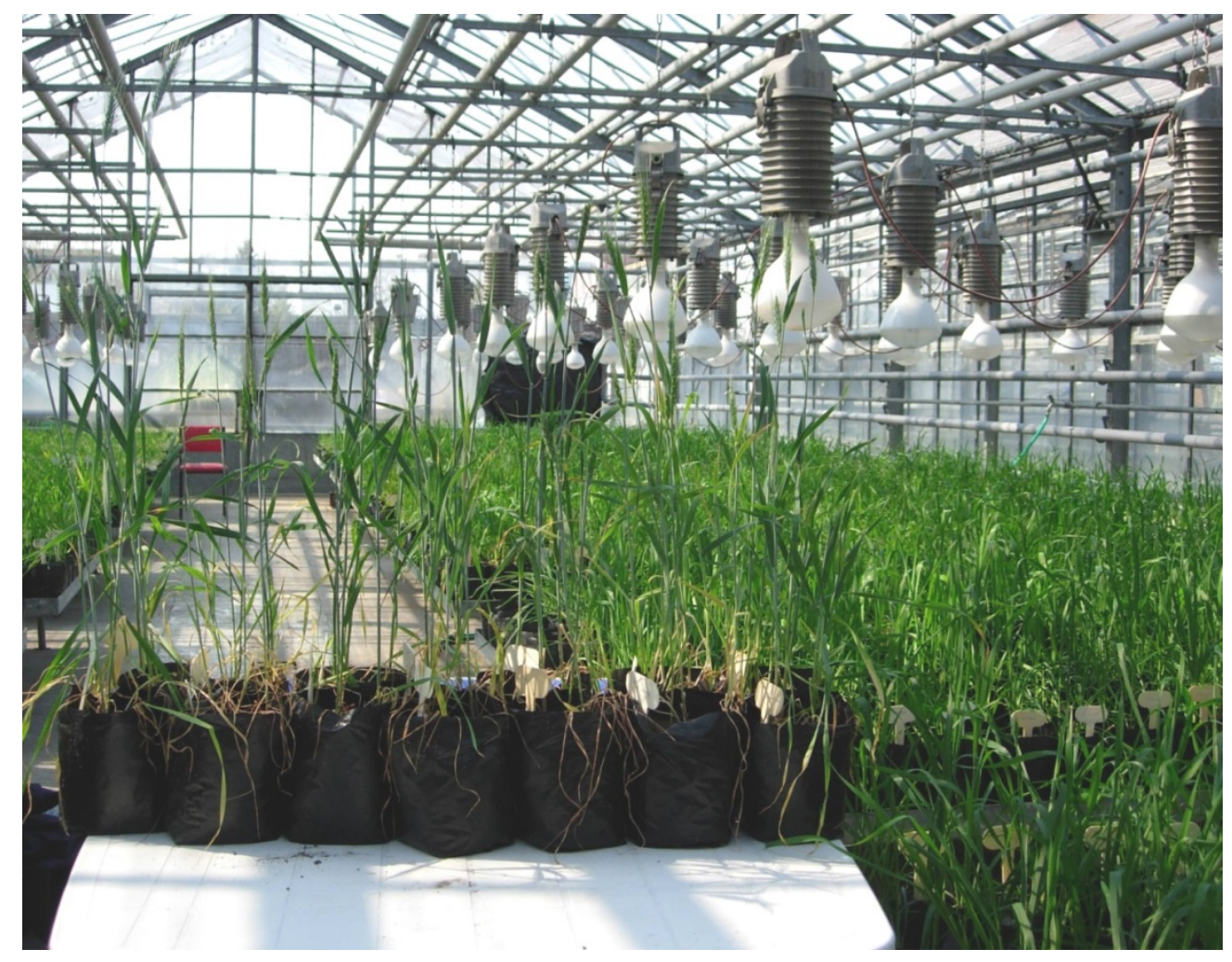

5. ábra: A szárazságstressz vizsgálatának növénynevelési helyszíne. A szegedi Gabonakutató Nonprofit Kft. üvegháza. 


\subsubsection{Alumíniumstressz vizsgálatához alkalmazott növénynevelés}

A kísérletek egyik részében egyhetes búzanövényekböl nyert fehérje kivonatot használtunk, ekkor a növények nem kaptak alumíniumkezelést. Ehhez a növényeket 24 órás szürőpapíron történő csíráztatás után két napra $0,5 \mathrm{mM}$-os $\mathrm{CaSO}_{4}(\mathrm{pH} 5,6)$ oldatban fejlődtek, majd módosított Hoagland tápoldatba (Zsoldos és mtsai. 1989) helyeztük a csíranövénykéket (3. táblázat). A növényházban $300 \mu \mathrm{mol} \mathrm{m} \mathrm{m}^{-2} \mathrm{~s}^{-1}$ fényintenzitáson, 12/12 óra fény/sötét megvilágítási periódussal, $25 / 20{ }^{\circ} \mathrm{C}$ nappali/éjszakai hőmérsékleten, $55-60 \%$ relatív páratartalom mellett nevelkedtek. A növények első kifejlett levelét használtuk fel a vizsgálatainkhoz.

\begin{tabular}{cc|cc}
\multicolumn{2}{c|}{$\begin{array}{c}\text { Makroelemek } \\
(\mathrm{mM})\end{array}$} & \multicolumn{2}{c}{$\begin{array}{c}\text { Mikroelemek } \\
(\mu \mathrm{M})\end{array}$} \\
\hline $\mathrm{Ca}\left(\mathrm{NO}_{3}\right)_{2}$ & 2,0 & $\mathrm{Fe}-\mathrm{EDTA}$ & 10 \\
$\mathrm{MgSO}_{4}$ & 1,0 & $\mathrm{H}_{3} \mathrm{BO}_{3}$ & 10 \\
$\mathrm{KH}_{2} \mathrm{PO}_{4}$ & 0,5 & $\mathrm{MnSO}_{4}$ & 1,0 \\
$\mathrm{Na}_{2} \mathrm{HPO}_{4}$ & 0,5 & $\mathrm{ZnSO}_{4}$ & 0,5 \\
$\mathrm{KCl}$ & 0,5 & $\left(\mathrm{NH}_{4}\right)_{6} \mathrm{Mo}_{7} \mathrm{O}_{24}$ & 0,1 \\
& & $\mathrm{Na}_{2} \mathrm{SiO}_{3}$ & 0,5 \\
& & $\mathrm{CoCl}_{2}$ & 0,1 \\
& & & \\
\hline
\end{tabular}

3. táblázat: Módositott Hoagland tápoldat összetétele $(p H=5,8)$.

(Zsoldos és mtsai. 1989).

$\mathrm{Az}$ alumíniumkezelésnél hasonlóan az előzőekben leírtakhoz csíráztattuk a búzamagokat és gyökereztettük $\mathrm{CaSO}_{4}$ oldatban. De csak 2 napig növekedtek módosított Hoagland tápoldatban. Ezután 5 napig 0,5 $\mathrm{mM} \mathrm{CaSO}_{4}$-t, $1 \mathrm{mM} \mathrm{KNO}_{3}$-t (pH 4) és 0, 10, 50 és $100 \mu \mathrm{M} \mathrm{AlCl}{ }_{3}$-t tartalmazó tápoldatban a kezeléseknek megfelelöen. A növényházi 
körülmények megegyeznek az előzőekben leírtakkal. Itt is az első kifejlett leveleket használtuk a vizsgálatokhoz.

\subsection{Fehérje kivonás és mennyiség mérés}

A begyüjtött levelekhez 1:3-as kivonási arányban adtunk hütött enzim extrakciós puffert, ami tartalmazott $200 \mathrm{mM}$ Tris-HCl-t, $2 \mathrm{mM}$ EDTANa $_{2}$-t, $3 \mathrm{mM}$ DTT-t, $1 \mathrm{mM}$ redukált L-glutationt, $10 \%$ glicerolt, $10 \mu \mathrm{l} / \mathrm{ml}$ proteáz inhibitor koktélt (Sigma-Aldrich, USA). Az kivonó puffer szerepe, hogy megakadályozza az enzimek degradációját a proteáz inhibitor segítségével, az $\mathrm{SH}^{-}$csoportok oxidációját a glutation végzi és a glicerol, mint detergens roncsolja a sejtmembránokat, így segítve a sejtek feltárását. A homogenizálást kerámia dörzscsészében kvarchomokkal végeztük 2-3 percig, majd Eppendorf-csövekben a homogenizátumot lecentrifugáltuk (6 min., 13000×g). A felülúszót használtuk a kísérletekhez, mint GS kivonatot, amit jégen tároltunk a felhasználásig. A minták fehérje tartalmát Bradford szerint (Bradford, 1976) határoztuk meg minden új növényi minta esetén.

Készítettünk fehérje kivonatot kloroplasztiszból is az előkészítő kísérletekben. Ebben az esetben 0,5 M szacharózt adtunk a kivonó pufferhez, és kétlépéses centrifugálással izoláltuk a kloroplasztiszokat. Az első centrifugáláskor (5 min., 1000×g) elválasztottuk a sejttörmeléket és a homokot a sejt szuszpenziótól, majd pedig a második centrifugálással (10 min., 13000×g) pedig már a fotoszintézist végző sejtorganellumokat ülepítettük ki az eppendorf csövekben.

\subsection{Glutamin szintetáz enzimaktivitás mérés}

A levelekben a glutamin szintetáz (GS, EC 6.3.1.2) jelenlétét, valamint aktivitását módosított szintetáz reakció segítségével tudjuk kimutatni és megmérni (Rhodes és mtsai. 1975). Az enzim egyik szubsztrátját, az ammóniumiont, hidroxilaminnal helyettesítjük:

$$
\mathrm{NH}_{2} \mathrm{OH}+\text { L-glutamát }+ \text { ATP } \longrightarrow \text { Me2+ } \longrightarrow \text {-glutamil-monohidroxamát }+\mathrm{ADP}+\mathrm{P}_{\mathrm{i}}
$$

Az így keletkező termék, a $\gamma$-glutamil-monohidroxamát (GMH), melynek mennyisége egyenesen arányos a GS specifikus aktivitásával. A keletkező GMH savas 
közegben $\mathrm{Fe}^{3+}$-ionokkal sárgásbarna komplexet képez. Így a keletkezett GMH mennyisége pontosan detektálható $540 \mathrm{~nm}$-es hullámhosszon spektrofotométerrel. A gyakorlatban a következö képpen végeztük el a GS aktivitás mérését: növényi mintához hozzáadtuk a reakció puffert (12 mM ATP, $20 \mathrm{mM} \mathrm{MgCl}_{2} \cdot 6 \mathrm{H}_{2} \mathrm{O}, \quad 65 \mathrm{mM} \mathrm{L}$-glutamát, $18 \mathrm{mM}$ hidroxilamin, $35 \mathrm{mM}$ imidazol, $\mathrm{pH}$ 7,5), majd 20 percig inkubáltuk az elegyet $30{ }^{\circ} \mathrm{C}$-on vízfürdöben. Ezután „Stop” oldattal $\left(370 \mathrm{mM} \mathrm{FeCl}{ }_{3} \cdot 6 \mathrm{H}_{2} \mathrm{O}, 670 \mathrm{mM} \mathrm{HCl}\right.$, $200 \mathrm{mM}$ TCA) leállítottuk a reakciót. A savas közeg miatt kicsapódott fehérjéket lecentrifugáltuk (6 min, 13000×g). Ezután a felülúszót vízzel háromszorosára hígítottuk, majd pedig megmértük az elegy extinkcióját fotométerrel $540 \mathrm{~nm}$-en (Secomam, Uvikon XL, Franciaország).

\subsection{Az alumínium hatásának vizsgálata a GS aktivitására}

A beállított kísérleti rendszerben a búza növények levelének fehérje kivonatához adtunk szerves alumínium komplexet, majd ebböl felvettünk egy kinetikai görbét növekvő magnézium koncentráció sor mellett $(0 \mathrm{mM}, 3,5 \mathrm{mM}, 7 \mathrm{mM}, 10,5 \mathrm{mM}, 14 \mathrm{mM}, 21,5 \mathrm{mM}$ és $32 \mathrm{mM}$ ). Az alkalmazott szerves komplexek az alumínium nitrilo-triecetsav komplexe volt $8 \mathrm{mM}$-os koncentrációban. Kontrollként desztillált vízet használtunk, illetve önmagában csak a NTA-t is alkalmaztuk. Természetesen a GS egyéb szubsztrátjait is biztosítottuk (12 mM ATP, $65 \mathrm{mM}$ L-glutamát, $18 \mathrm{mM}$ hidroxilamin, $35 \mathrm{mM}$ imidazol, $\mathrm{pH} 7,5)$. Az elegyeket 20 percig inkubáltuk $30{ }^{\circ} \mathrm{C}$-on és a fentebb leírt „Stop” oldattal állítottuk le a reakciót és mértük meg az oldatok extinkcióját spektrofotométerrel.

\subsection{Natív poliakrilamid gélelektroforézis}

A fehérjék natív, molekulasúlytól és felületi töltéstől függő elválasztását Laemmli módszerével végeztük (Laemmli 1970), ennek lényege, hogy a fehérjék megtartják eredeti, müködőképes (natív) konformációjukat és felületi töltésüket. A stacking gél 3,13 T\%-os volt, a szeparáló gél $6,5 \mathrm{~T} \%$-os, a gél vastagsága $1,5 \mathrm{~mm}$. A gél részletes összetétele a 4. táblázatban látható. A zsebekbe $100 \mu \mathrm{g}$ fehérje mintát vittünk fel tized mennyiségü minta pufferrel, majd futtattuk a mintát $150 \mathrm{~V}$ feszültséggel és $25 \mathrm{~mA}$ áramerősséggel a futási frontot mutató festék (brómfenolkék) kifutását követő +10 percig, ez hozzávetölegesen 3 órahosszás futtatásokat jelentett. Az elektroforézishez Mini-Protean II Dual Slab (BIO-RAD) függőleges elrendezésủ cellát, EPS 3051 XL (Amersham Biosciences, Egyesült Királyság) és ESP 500/400 (Pharmacia LKB, Svédország) 
tápegységet használtunk. A katód puffert 1 órányi futtatás után hidegre cseréltük a gél túlmelegedésének elkerülésének érdekében, ugyanis az erős felmelegedés a fehérjék futásában deformitásokat okoz (hullámosodás, elkenődés). Az egységes térfogatnyi minta felvételével elértük, hogy a friss tömegre vonatkoztatott fehérjemennyiségeket látjuk a megfestett és blottolt géleken.

\begin{tabular}{|c|c|c|}
\hline & Stacking gél & Szeparáló gél \\
\hline Akrilamid/Bisz-akrilamid & $3,12 \% \mathrm{~T}$ & $6,6 \% \mathrm{~T}$ \\
\hline Gélpuffer törzsoldat (957 mM Tris- & - & $240 \mathrm{mM}$ \\
\hline $\mathrm{HCl}, \mathrm{pH} 8,5)$ & & \\
\hline Gélpuffer törzsoldat (158 mM Tris, \\
$\left.0,256 \mathrm{~N} \mathrm{H} \mathrm{HO}_{4}, \mathrm{pH} 6,9\right)$
\end{tabular}

4. táblázat: A natív poliakrilamid gél összetétele.

\subsection{A GS aktivitásmérése poliakrilamid gélben}

A géleket az elektroforézis befejezése után a felhasználandó oldatok térfogatának minimalizálása és az oldatok és a gél minél jobb kontaktusának kialakítása érdekében polietilén zacskóba zártuk. Először a GS aktiválásához szükséges oldatot adtuk a gél mellé. Az oldat tartalmaz 10 ml-nyi 30 mM-os $\mathrm{MgCl}_{2}$ és 50 mM-os imidazolt, az oldat pH-ja 7,2. 10 perc folyamatos rázatással átmostuk a gélt. Ezután $10 \mathrm{ml}$ reakció puffert adtunk a gélekhez. A $10 \mathrm{ml}$ reakcióelegy tartalmaz $50 \mathrm{mM}$-os imidazolt $21 \mathrm{mM}$-os $\mathrm{MgCl}_{2}$-t, $18 \mathrm{mM}$-os ATP-Na $-\mathrm{t}, 25 \mathrm{mM}$-os hidroxilamint, valamint $52 \mathrm{mM}$-os L-glutamátot. 
A géleket $30{ }^{\circ} \mathrm{C}$-os hőmérsékleten 20 percig rázatva inkubáltuk. Az inkubációs idő letelte után $10 \mathrm{ml}$ „Stop” oldattal, ami 370 mM-os $\mathrm{FeCl}_{3}$-ot, $670 \mathrm{mM}$-os HCl-t és $200 \mathrm{mM}$ TCA-t tartalmaz, állítottuk meg az enzimreakciót és hívtuk elő a színreakciót a termékkel. A „Stop” oldatban a TCA szerepe az fehérjék kicsapása volt (így minden enzim müködése leállt), a $\mathrm{FeCl}_{3}$ szerepe pedig a komplexképzés volt a $\mathrm{GMH}$-val. A keletkezett komplex a gélben történő gyors diffúziójának elkerülésének érdekében azonnal szkenneltük a géleket, hogy digitális formában tárolható képeket nyerjünk róluk, és a későbbiek során így tudjuk azokat elemezni. A gélek digitalizálást HP 3970 típusú szkennerrel végeztük (Pécsváradi és mtsai. 2009).

Ez a módszer alkalmas a hajtásban lévő GS izoenzimek elkülönítésére, ugyanis a GS1-nek az aktivitása nem számottevő, azonban a GS2 helyzete ezzel a módszerrel meghatározható a gélben, mivel a hajtásban a GS2-nek van számottevő aktivitása. A western blot eredmények megerősítették a GS izoenzimek aktivitásának vizsgálatával kapott gélbeni poziciókat. Így a későbbiekben a GS2 helyzetét a gél egy szeletében végzett aktivitás méréssel határoztuk meg. Ennek alapján a gél intakt részéböl izoláltuk a GS2 sávot, amit a további kísérletekben használtunk fel.

\subsection{Poliakrilamid gélek festése, szárítása, dokumentálása}

Ahhoz, hogy a natív poliakrilamid géleken láthatóvá tehessük a fehérjéket először fixáló folyadékba kellett helyeznünk, ami 40\% metanolt és $10 \%$ ecetsavat tartalmazott. Ebben inkubáltuk a géleket egy éjszakán keresztül. Majd 0,025\%-os Coomassie Brillant Blue G-250-t és 10\% ecetsavat tartalmazó oldatban festettük a géleket 20 percen keresztül, majd 10\%-os ecetsavas oldatban távolítottuk el a felesleges festéket, ami nem kötődött a fehérjékhez, ez körülbelül 2-3 órás mosást jelent félóránként cserélve az ecetsavas „destaining” oldatot (Neuhoff és mtsai. 1985 alapján). A gélek digitalizálást HP 3970 típusú szkennerrel végeztük ebben az esetben is. A dokumentálás után megszárítottuk a géleket $70{ }^{\circ} \mathrm{C}$-on 1 órán keresztül egy erre alkalmas készülékkel (Gel Dryer, Model 543, Bio-Rad, USA). Az így megszárított gélek hosszú ideig eltárolhatóak szobahőmérsékleten normál körülmények között.

\subsection{Western blot}

A gélek egy részén a futtatás után western blot analízist is végeztünk, hogy megállapítsuk az adott futtatási körülmények között a GS pontos elhelyezkedését a gélben. 
Semi-dry blottolást alkalmaztunk, ahol PVDF membránra kötöttük rá a fehérjéket. A blottolást Multiphore II (Pharmacia, Svédország) eszközzel végeztük $50 \mathrm{mM}$-os borát pufferrel (pH 9), ahol az anód oldali puffer $4 \%$ metanolt tartalmaz még a borát mellett. A futtatási paraméterek: 90 perc, $100 \mathrm{~V}$ és $1 \mathrm{~mA} / \mathrm{cm}^{2}$ a blottolási felületnek megfelelően. A membránok felületét 2\%-os albumin oldattal telítettük, hogy megakadályozzuk a nemspecifikus kölcsönhatásokat a membrán és az antitestek között. A GS-re elsődleges antitesként poliklonális anti-GS antitestet kötöttünk (külön köszönet J.V. Cullimore-nak). Ezután TTBS (0,2 M Tris bázis, 1,5 M NaCl, 0,05\% TWEEN 20) és TBS (0,2 M Tris bázis, 1,5 M NaCl) oldattal mostuk a membránokat. A másodlagos antitest alkalikus foszfatázzal konjugált Protein-A volt. Az előhívó pufferben (1 M Tris bázis, $1 \mathrm{M} \mathrm{NaCl}, 5 \mathrm{mM} \mathrm{MgCl}$ ) 5 percig inkubáltuk a membránokat, majd az alkalikus foszfatáz megfelelő szubsztrátjait (BCIP-t és NBT-t) hozzáadtuk az előhívó pufferhez. Ez a két vegyület reagálva az alkalikus foszfatázzal lilás, oldhatatlan terméket képez. Fontos, hogy az előhívás sötétben történjen, mert a szubsztrátok fényérzékenyek. A már elöhívott blotmembránoknál is ügyelni kell, hogy fénytől elzárt helyen tároljuk (Bennett és Cullimore, 1989).

\subsection{Az alumínium és magnézium detektálása}

Az intakt gélből az előzetesen meghatározott (glutamin szintetáz aktivitásának mérése gélben) GS-t tartalmazó és GS-t nem tartalmazó kontroll sávokat kivágtuk (19. ábra) és összegyüjtöttünk 4 ml-nyi gélszelet, majd mikrohullámú roncsolásra került sor salétromsavas közegben (lásd lentebb, de szárításra és hígításra nem került sor). Ennek eredményeképpen egy víztiszta oldatot kaptunk, amin már el lehetet végezni a kémiai analízist.

Növényi részek alumínium és magnézium tartalmát is meghatároztuk, ennek menete a következő volt: A növényi szerveket $70{ }^{\circ} \mathrm{C}$-on 72 óráig szárítottuk majd $65 \%$-os salétromsavban és $30 \%$-os $\mathrm{H}_{2} \mathrm{O}_{2}$ oldatban (tömeg/térfogat százalékok) mikrohullámú roncsolásra került sor $\left(200{ }^{\circ} \mathrm{C}, 1600 \mathrm{~W}, 15\right.$ perc $)$. Ezután hagytuk kihülni, majd pedig háromszorosára hígítottuk dessztillált vízzel a mintákat és ezt követte a fémionok mennyiségének mérése.

A fémionok mennyiségének meghatározását ICP-AES-el végeztük el. Az alumínium esetében 396,152 nm, magnézium esetében 279,553 nm az emissziós hullámhossz, a detektáláshoz Jobin-Yvon 24 típusú argon spektrométert használtunk Teflon V-groove párologtatóval és Gilson Minipuls 3 perisztaltikus pumpával. Ennek a vizsgálatnak a 
lényege, hogy gerjesztődnek hő hatására a fém ionok és mikor a gerjesztett állapotról visszatérnek nyugalmi, stabil állapotba, akkor egy meghatározott, csak az adott ionra jellemző hullámhosszúságú fotonsugárzást bocsátanak ki. Ez a technika tehát alkalmas az ionok nagy érzékenységü minőségi és mennyiségi meghatározására is. Mivel a detektált hullámhossz a fémion fajtáját mutatja meg, a fotonok mennyisége pedig arányos a fémionok mennyiségével. Tehát ez a berendezés a befecskendezett mintát gerjesztési állapotig felhevíti, majd a gerjesztett ionok által kibocsátott hullámhosszt megfelelő detektorral érzékeli (Pécsváradi és mtsai. 2009).

\subsection{Statisztikai kiértékelés}

A vizsgálati eredmények matematikai-statisztikai feldolgozását és kiértékelését a Microsoft Office Excel szoftverrel végeztük. Minden mérésnél a kontroll és kezelt növények adatait kétmintás t-próbával hasonlítottuk össze. A dolgozatban ábrázolt adatok 3-5 független minta átlag értékei, és a szórás értékek is ábrázolva vannak $( \pm \mathrm{SD}$, standard deviancia). 


\section{Eredmények}

\subsection{Előkészítő kísérletek}

\subsubsection{A GS izoenzimek lokalizációja poliakrilamid gélben}

Annak érdekében, hogy megfelelő módon tudjuk vizsgálni a glutamin szintetáz aktivitását, fémtartalmát és az izoenzimek mennyiségét a különböző növényi szervekben szükséges volt előkészítő kísérletek elvégzése. Fehérje izolátumot készítettünk 1 hetes búza növények teljes leveléből, az abból izolált kloroplasztiszból és a gyökérből. Majd pedig natív poliakrilamid gélen (PAGE) megfuttatva a fehérje kivonatokat megfestettük proteinekhez kötődő festékkel, western blot-ot készítettünk belöle (GS izoenzimek azonosítása) és aktivitást is mértünk a gélben. A kapott eredmény a 6. ábrán látható.

\section{Levél}

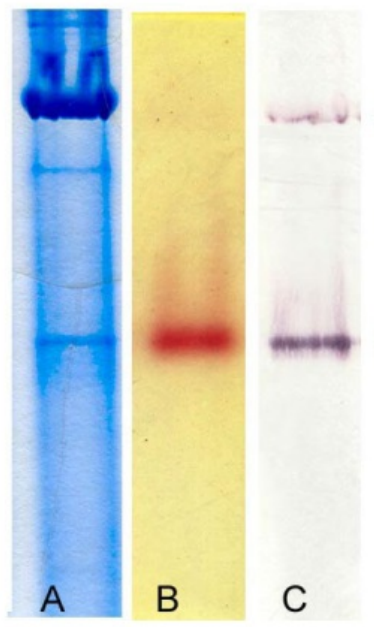

Kloroplasztisz

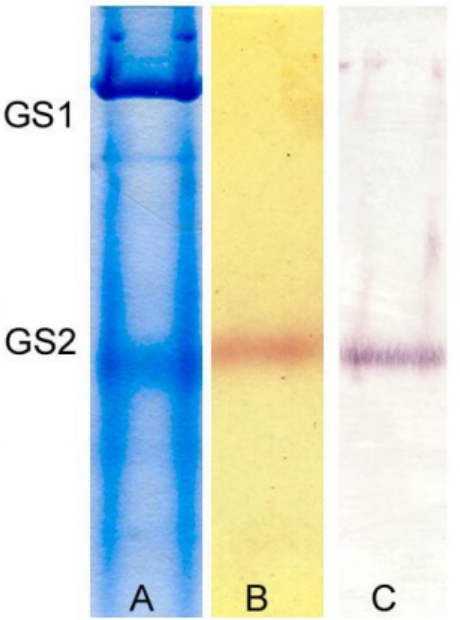

Gyökér

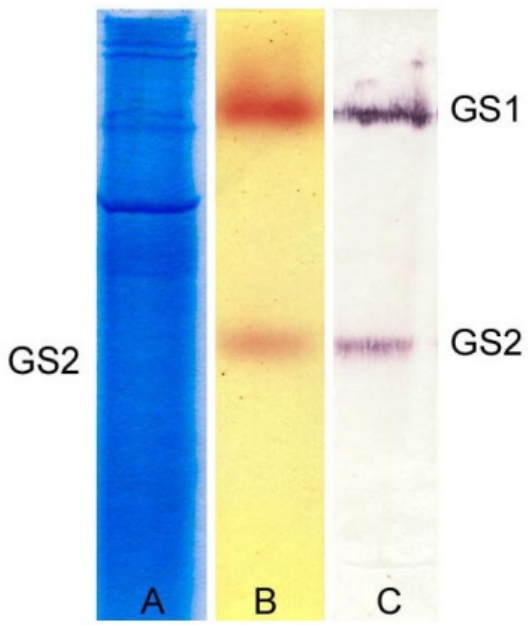

6.ábra: Elektroforetikus úton szeparált és kimutatott plasztidikus és citoszólikus glutamin szintetáz izoenzimek egyhetes búza növény elsö leveléböl.

A: Coomassie G-250-vel festett poliakrilamid gél, B: GS aktivitás kimutatása gélben,

C: Western blot analizis eredménye GS izoenzimekre 
Az A-val jelölt részen az ábrának a Coomassie Brillant Blue G-250-el festett gél egy zsebének az oszlopa látható. Itt megfigyelhetjük a levélben és a kloroplasztiszban nagy tömegben jelenlévő Rubisco sávját (a gél felső részén, a western blot-on jelölt GS1 sávjával egyvonalban), valamint a GS2 halvány sávját. A növényi levél sejtek a fehérje tartalmának több mint felét (általában 50-60\%) a Rubisco enzim adja, sajnálatos módon, ez a fehérje megnehezíti emiatt a többi fehérje vizsgálatát, jelen esetben a glutamin szintetáz citoszólikus izoenzimét (GS1). PAGE vizsgálatoknál a gél könnyen túlterhelődhet. A gél kis térfogatában túl sok fehérje halmozódik fel és emiatt megváltozik az elválasztás hatékonysága, ugyanis telítődnek a gél pórusai és akadályozódik a fehérjék mozgása. Ha nem megfelelö mennyiségü mintát viszünk fel, emiatt romlik a sávok élessége, valamint a sávok, hajlamosak a Rubisco sávjának a közelében torzulni, ez látható az ábrán is, ezért a gél értékelése nehezebb, sőt néha lehetetlenné válik. Emiatt is volt szükséges megvizsgálnunk a GS izoenzimek elhelyezkedését, hogy lássuk, milyen mértékben torzítja a sávjukat a Rubisco. Az ábrán láthatjuk, hogy a GS1 sávja nagyon közel van a Rubisco sávjához, emiatt annak vizsgálata nehézkes, és a western blot-nál (az ábrának a $\mathbf{C}$ része) jól látható, hogy a Rubisco mennyire deformálta a GS1 sávját, valamint azt is látjuk, hogy a GS1 mennyisége jóval kevesebb, mint a GS2-é. Láthatjuk azonban, hogy a GS2 távol helyezkedik el a Rubisco sávjától (és a GS1-től is), így alkalmas arra, hogy ez az izoenzim legyen vizsgálatunk tárgya. Azt is megállapíthatjuk ebből a kísérletből, hogy számottevő aktivitása csak a GS2-nek van, ez az ábra B-vel jelölt sávján látható, ahol magában a poliakrilamid gélben adtunk a natív GS számára szubsztrátokat és láthatjuk a vas-kloriddal barnás-vörös színü csapadékot adó terméket, a GMH-t.

A GS2 aktivitás nagyságának a magyarázata abban áll, hogy a levélben ez az enzim látja el teljes mértékben a nitrogén asszimiláció feladatát, a GS1 csak nyomokban van jelen, és nincs szerepe a primer nitrogén anyagcserében, ennek oka az, hogy a búza C3-as fotoszintézist müködtet valamint a nitrit reduktáz is a kloroplasztiszban helyezkedik el. Természetesen, ha gyökérböl vettünk volna mintát ott más lett volna a helyzet, mivel ott a GS1 van nagyobb mennyiségben a GS2-höz képest. A western blot eredményeknél még ki kell emelni, hogy az általunk használt elsődleges GS antitest jobban kötődik a GS1 izoenzimhez, mint a GS2-höz. Ez a sötétebb festődésen látszik, de a festődött terület nagyságáról tudunk következtetést levonni az izoenzimek mennyiségéről és nem a festődés mértékéböl. 


\subsection{A szárazságstresszhez kapcsolódó vizsgálatok eredményei}

\subsubsection{Növények állapota}

A szárazság stressz vizsgálatakor első feladatunk volt a növények állapotának felmérése. Dolgozatomban a két nemzetközi fajtát és a Kobomugi tájfajtát emelném ki, de a többi genotípus esetében is ilyen hasonló tendenciák voltak megfigyelhetőek. 7., 8. és 9. ábrán láthatók a kontroll és a vízmegvonásnak kitett növények fotói. A Plainsman V-röl és a Kobomugiról a mintavételezés idején készültek a fotók növénynevelésre igénybe vett üvegházban. De ekkor még a Cappelle Desprez még nem virágzott. Ezért van az hogy a 7. ábrán látszik, hogy a Plainsman V-vel összehasonlítva a Cappelle Desprez-nél még a kalászt takarja a zászlós levél, ezt nevezzük „kalász hasban” állapotnak. Ennek oka, hogy a növények nem azonos sebességgel fejlödnek. A Plainsman V és a Kobomugi korai fejlődésü, míg a Cappelle Desprez lassabb fejlödésü. A növények levél mérete sem volt teljesen azonos, ennek genetikai háttere van, de ez a tulajdonság természetesen hat a növények vízháztartására. Habár a fotók azonos időben készültek a mintavételezés minden esetben DPA 9-kor történt.

a)

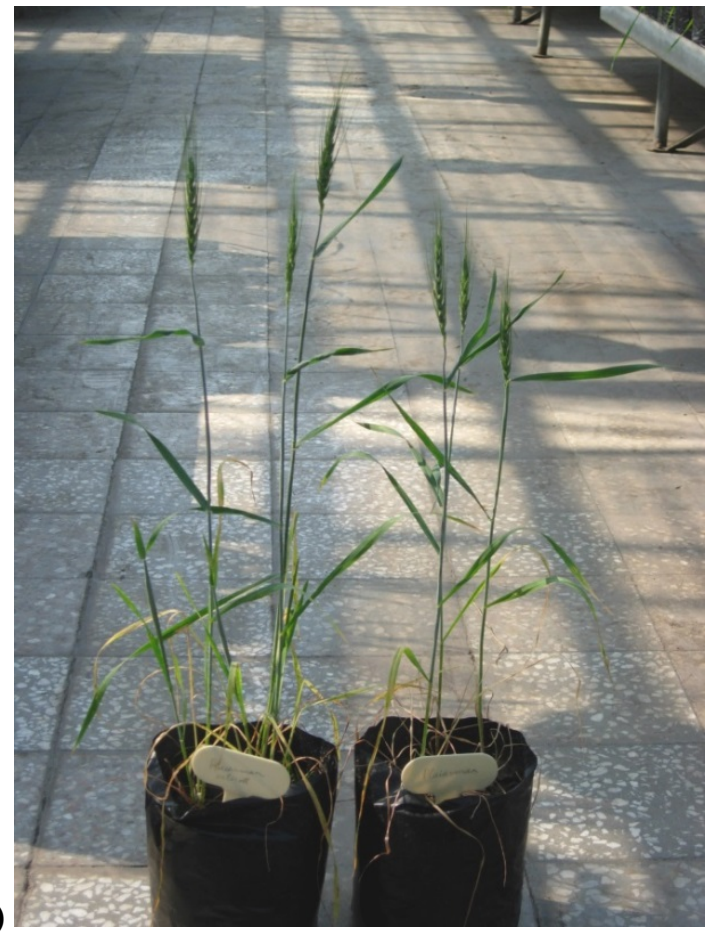

b)

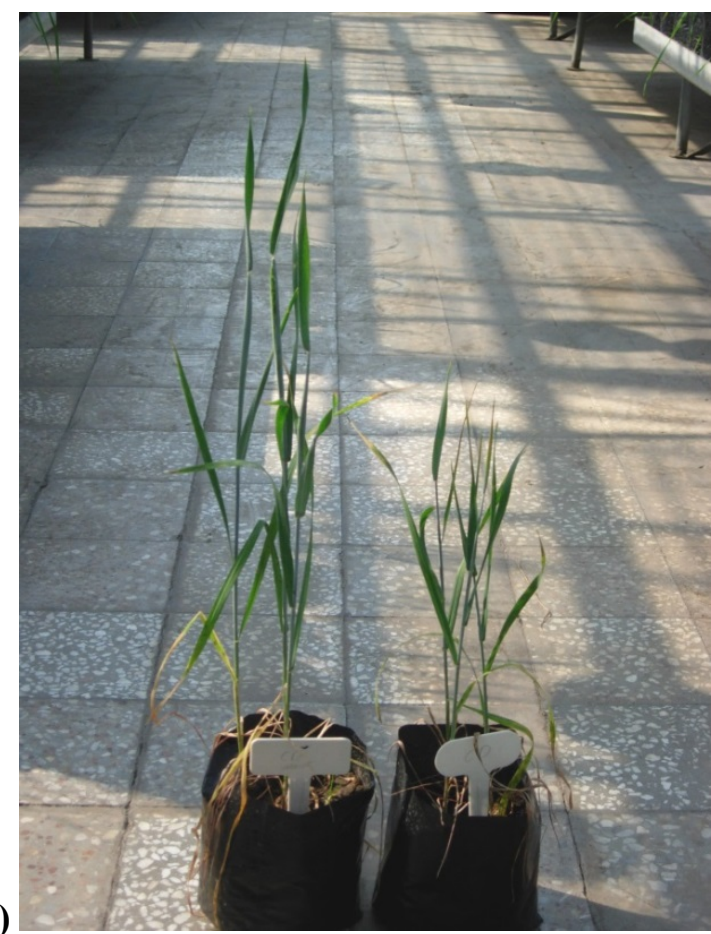

7. ábra: A szárazságstressz vizsgálatában résztvevő búza növények. A fotók bal oldalán az öntözött növények láthatóak, míg jobb oldalt a vízmegvonásban részesültek.
a) Plainsman $V$
b) Cappelle Desprez 
Azonban jól megfigyelhető a szárazság érzékeny Cappelle Desprez genotípuson, hogy jelentős szármagasság csökkenést tapasztalunka vízhiány hatására. A szárazság toleráns Plainsman V fajtánál is látszódik a kisebb növénymagasság, de a különbség sokkal kisebb mértékű. A két genotípus között látszódik a szárazságstresszre adott eltérő válasz. A Cappelle Desprez nem csak saját öntözött kontrolljához képest, hanem a Plainsman V vízhiányt elszenvedő egyedekhez képest is jelentősebb kisebb szárral rendelkezett. A szármagasságon kívül még érdemes megfigyelni, hogy a szárazságstressznek kitett egyedeknél az összes zöld levélfelület is kisebb.
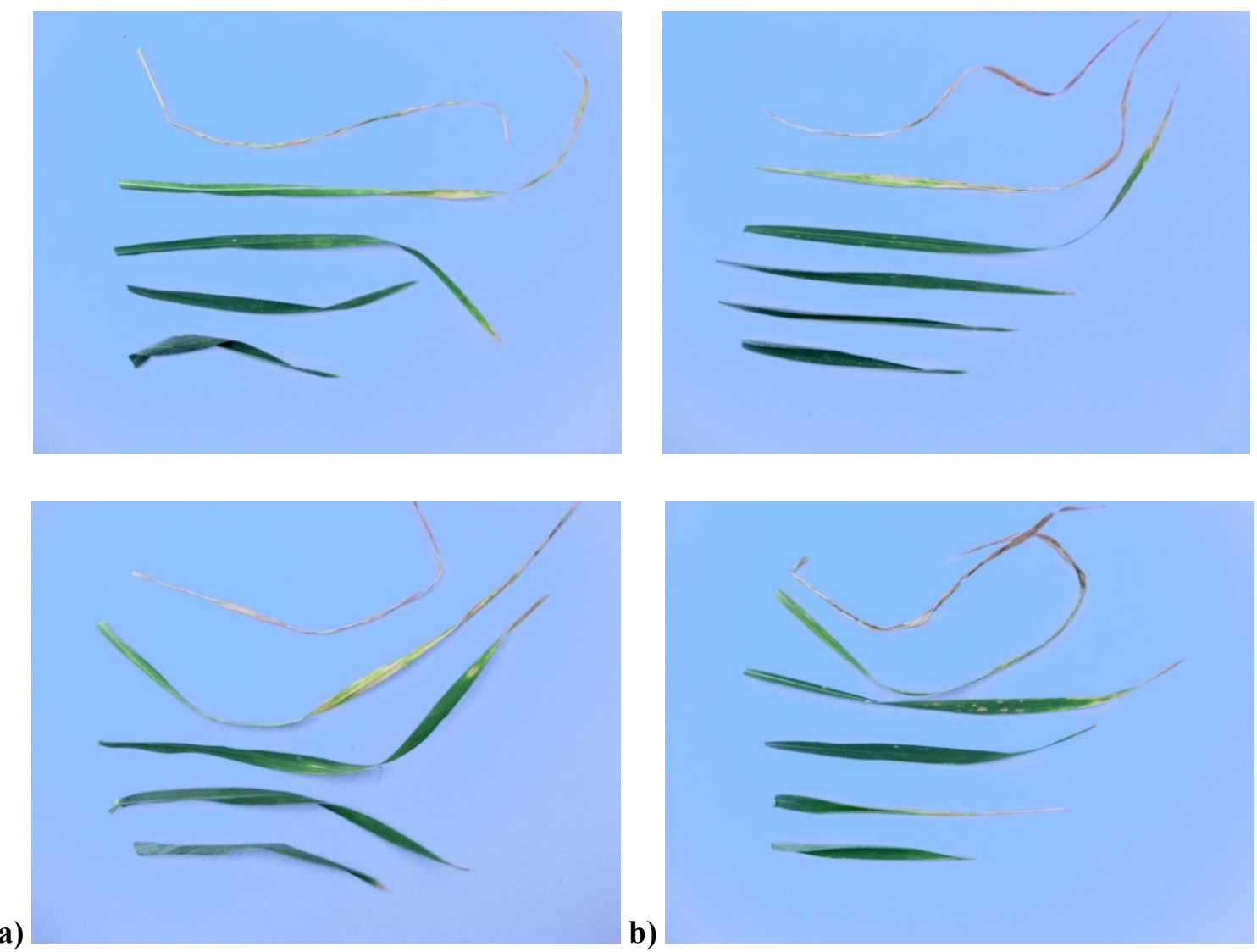

8. ábra: A szárazságstressz vizsgálatában résztvevő búza növények kalász alatti leveleinek összehasonlitása a virágzás utáni kilencedik napon (DPA 9). A felsö képpáron az öntözött növények levelei az alsón a vizhiánynak kitett növények levelei láthatóak. A kalászhoz legközelebbi levél a kép alján helyezkedik el.

a) Plainsman $V$ b)Cappelle Desprez 
A 8. ábrán a kalász alatti levelek összehasonlítása látható DPA 9 időpontban. A későbbiekben ezekből a levelekből történt meg a fehérje kivonás is. Ahogy a teljes növények fotóján is észrevehető volt a Cappelle Desprez több levéllel és nagyobb levélfelülettel rendelkezik, mint a Plainsman V. A levelek szekvenciális, fokozatos öregedése jól látható az öntözött növényeknél, mind két genotípus esetében egyformán. Az alsó levelek fokozatosan vesztik el klorofill, majd víztartalmukat is, a levelek elsárgulnak, majd összeszáradnak egy irányított és szabályozott folyamat során.
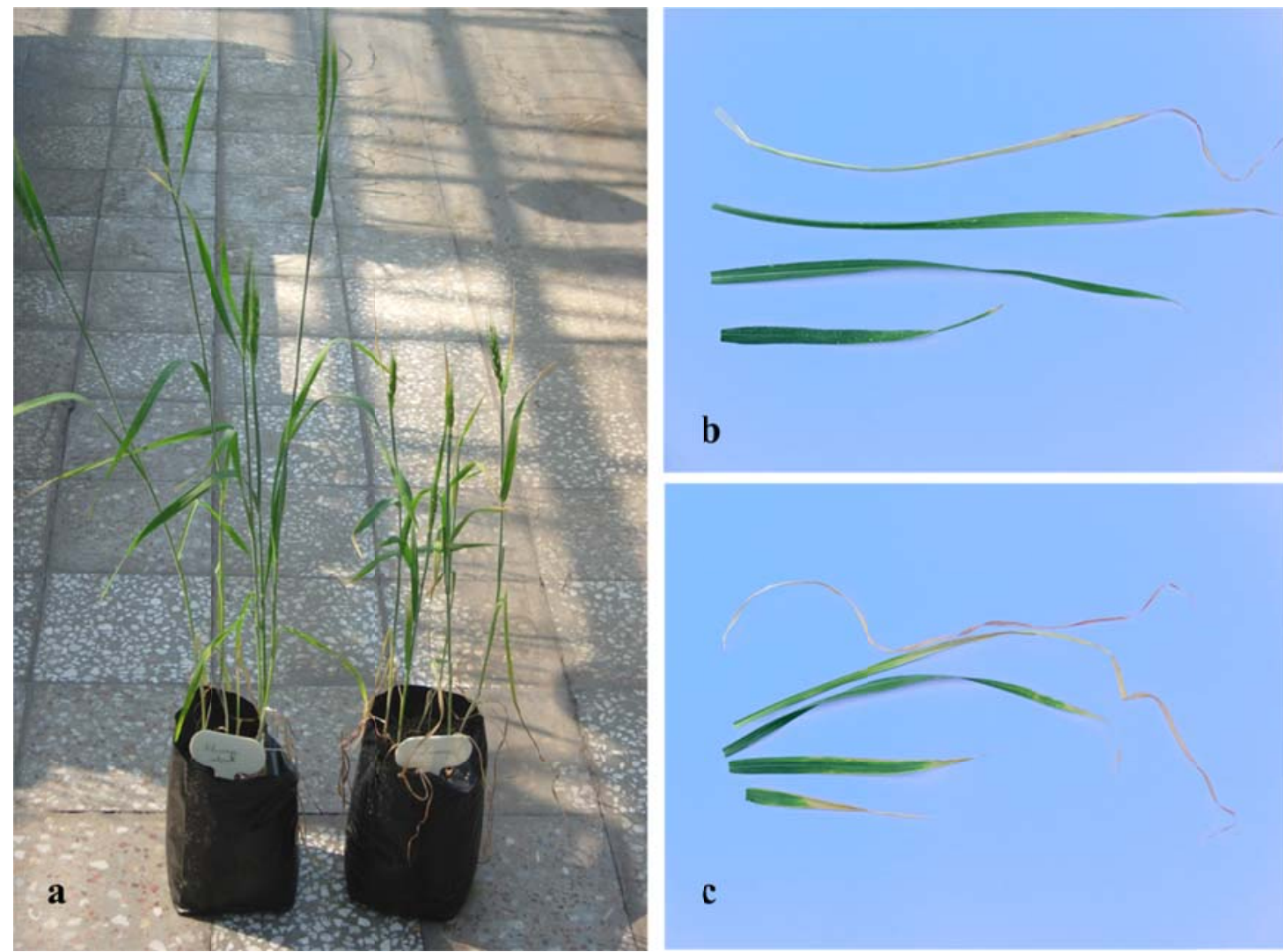

9. ábra: A Kobomugi tájfajta reakciója a szárazságstresszre. A fotók a virágzás utáni kilencedik napon készültek.

a) Az öntözött (bal oldali) és a szárazságstressznek kitett (jobb oldali) növények

b) Az öntözött növény levelei. c) szárazságstressznek kitett növény levelei.

Szárazságstressz esetén eltérő folyamatokat észleltünk a két búzafajtában. Ahogy a fotókon is láthatjuk, a Plainsman V esetében megmarad a gyökér felöli fokozatos öregedés, annyi változással, hogy a kalásztól számított harmadik levél is mutatja már a szeneszcencia jeleit, a levélcsúcs elkezdett sárgulni. A Cappelle Desprez esetében azt látjuk, hogy a zászlós levél alatti levél kezd el öregedni, sárgább a színe, mint a fölötte és az alatta lévő 
levél. Természetesen a levelek alulról való öregedése itt is gyorsult, de meglepő módon magasabb levélszinten lévő levél is mutatja a szeneszcencia jeleit. Elmondhatjuk tehát, hogy Cappelle Desprez és a Plainsman V másképp reagál a szárazságstresszre és ez már egyértelmü külső jelekben is megnyilvánul.

A 9. ábrán a Kobomugi tájfajtáról és leveleiről készült fotók láthatóak. A Cappelle Desprezhez hasonló változásokat láthatunk a vízhiány hatására. De ebben az esetben maga a zászlóslevél mutatja a leggyorsabb elszáradást.

\subsection{2 Összes oldott fehérje- és Rubisco tartalom}

A 10. ábrán láthatóak az előzőleg megfigyelt növények kalász alatti leveleinek fehérjetartalma, illetve a Coomassie Brillant Blue G-250 festéssel a relatív Rubisco tartalomra is lehet következtetni. Amit első eredményként el lehet mondani, hogy a fehérje tartalom úgy alakul, ahogy a növény és a levelek állapotából elvárhatjuk. Az öntözött körülmények között a szekvenciális öregedés miatt látjuk azt, hogy a gyökérhez közelebbi levelekben drasztikusan lecsökken a levelek oldott fehérjetartalma. Bár az egyértelmüen látszik, hogy a grádiens a Plainsman V fajta esetében markánsabb. A Cappelle Desprez esetében a fehérje tartalom nem csökken olyan drasztikusan, sőt a zászlóslevél alatti két levél fehérje tartalma közel azonos. Elmondható az is hogy a Cappelle Desprez összfehérje tartalma átlagosan magasabb, mint a Plainsman V-é. A vízhiány hatására láthatjuk, hogy a Plainsman V genotípus esetében szinte nincs is számottevő eltérés az öntözött növényekhez képest. A fehérje tartalmak nem alacsonyabbak, az öregedéssel járó fehérje tartalom változási tendenciák az egyes levelekben hasonlóak. A Cappelle Desprez esetében azonban a zászlóslevél fehérjetartalma sokkal alacsonyabb értéket mutat, mint a kalásztól számított második, harmadik és negyedik levél. A legmagasabb fehérjetartalmat a kalásztól számított harmadik levél mutatja. Érdekes még az a megfigyelés, hogy habár a zászlóslevélben lecsökken jobban a fehérjetartalom, mint az alatta levő két levélben, a negyedik levélben még így is magasabb fehérje koncentráció van, mint a Plainsman $\mathrm{V}$ öntözött növények negyedik levelében.

A Rubisco mennyisége a Coomassie Brillant Blue festett gélekről készült fotók alapján egyértelmü korrelációt mutat az összes vízoldható fehérje mennyiségével. Plainsman $\mathrm{V}$ esetében az öntözött és vízhiányos körülmények között azonosak a tendenciák. Azonban az elmondható, hogy a Rubisco mennyisége kevesebb a stresszelt növényekben, mint az öntözöttben mindkét fajta esetében. Cappelle Desprez esetében 
pedig jól látszódik a csökkent enzim mennyiség a zászlós levélben az alatta lévő két levélhez képest szárazságstressz alatt.
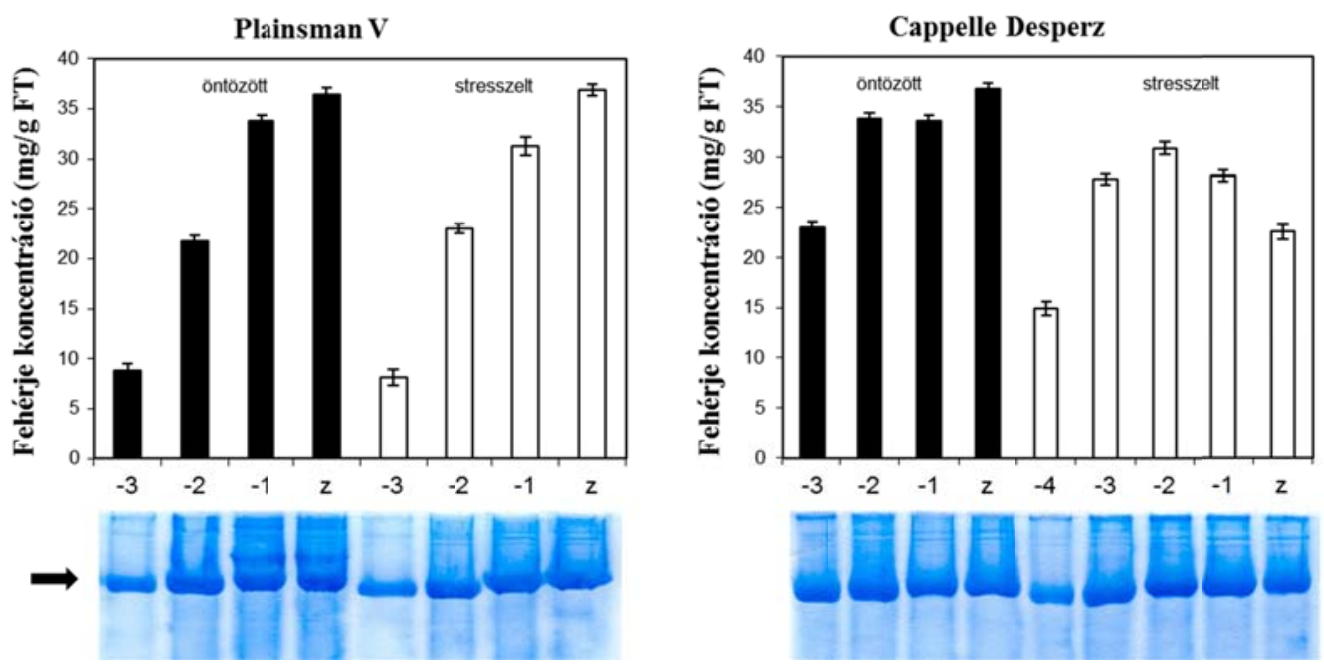

10. ábra: A Plainsman Vés Cappelle Desprez búza fajták kalász alatti négy levelének összes oldott fehérje tartalma és viszonyított Rubisco tartalma a virágzás utáni kilencedik

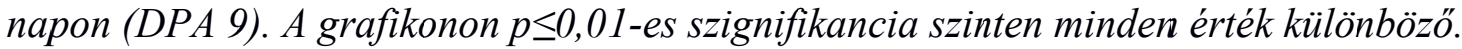

A jelölt értékek három mérés átlagát és szórását mutatják.

z: zászlóslevél -1, -2, -3,-4: a zászlóslevéltöl számitva következö levelek

\subsubsection{Glutamin szintetáz aktivitás és mennyiség}

A 12. ábrán a friss tömegre vonatkoztatott GS aktivitási értékekett látjuk a Plainsman V és Cappelle Desprez genotípusok esetében. A fehérjetartalomra vonatkozó GS aktivitás ábrázolásának az a hátránya, hogy a drasztikusan változó „egyéb” fehérjetartalom mellett nem mutat valós képet a glutamin szintetáz tényleges fehérjetartalomra vonatkoztatott aktivitásáról. Ez jól megfigyelhető a 11. ábrán. Ennek oka, hogy a fehérje tartalom változása nem arányos a glutamin szintetáz aktivitás változásával. A western blot eredményekkel összevetve az aktivitás értékeket láthatjuk, hogy legjobban a friss tömegre vonatkoztatott enzimaktivitások adják vissza a western blot-tal kapott eredményeket, és a későbbiekben is csak a frisstömegre vonatkoztatott enzimaktivitási értékeket mutatom be. Ha a fehérje tartalmak közel azonos módon változnának, illetve nem mutatnának nagy eltéréseket akkor a fehérje mennyiségre vonatkozó enzimaktivitási adatokat is lehetne használni, hogy értékelhető eredményeket kapjunk. 


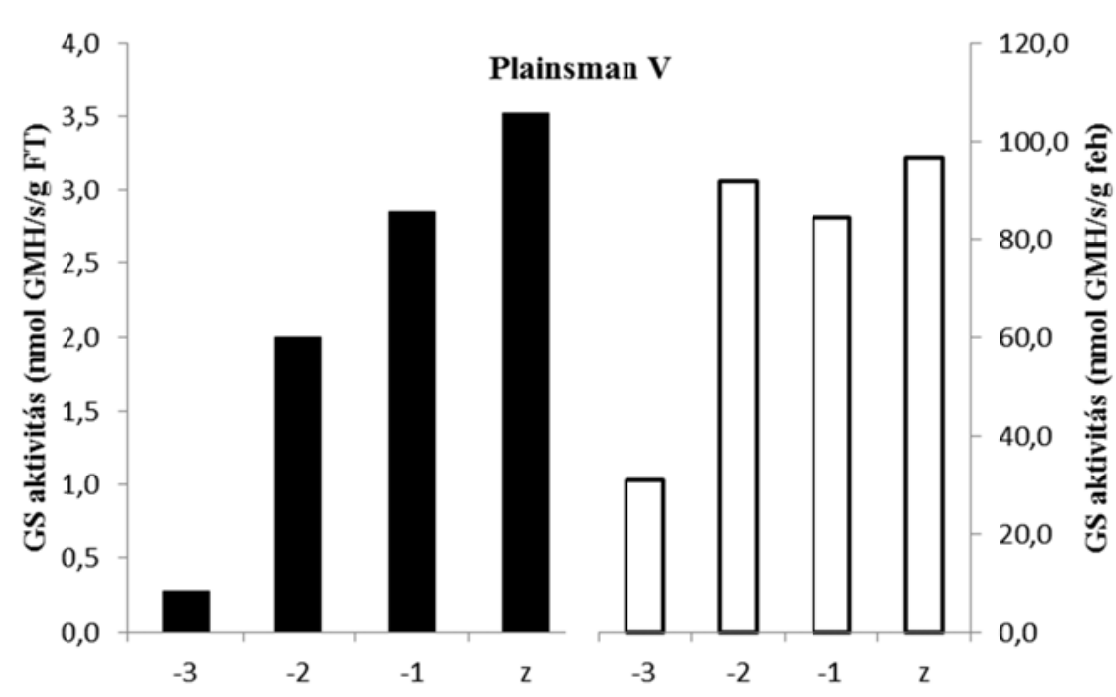

11. ábra: A glutamin szintetáz aktivitása öntözött Plainsman V növényekben friss tömegre (fekete oszlopok) és fehérjemennyiségre (fehér oszlopok) vonatkoztatva a virágzás utáni kilencedik napon (DPA 9). A jelölt értékek három mérés átlagát jelöli, szórás nincs feltüntetve.

z: zászlóslevél -1, -2, -3: a zászlóslevél után következö levelek a gyökér felé

A 12. ábrán megfigyelhetjük az enzim aktivitás és a glutamin szintetáz izoenzimek mennyisége közötti összefüggéseket a két nemzetközi búza genotípus esetében öntözött és vízhiányos körülmények között. Jól látható, hogy az enzimaktivitási értékek azonos tendenciát mutatnak az izoenzimek mennyiségi változásával. Az öregedő levelekből eltünik a glutamin szintetáz. Ha a 10. ábrán lévő fehérje koncentráció értékekkel hasonlítjuk össze az enzim aktivitási értékeket itt is azt látjuk, hogy ott ahol magasabb a fehérje mennyiség ott magasabbak az enzim aktivitási értékek is. Tehát itt is azonos tendenciákat látunk. A Plainsman $\mathrm{V}$ fajtában a szárazságstressz nem töri meg a szekvenciális levélöregedési folyamatot, azonban a Cappelle Desprez esetében látjuk, hogy a zászlós levélben alacsonyabb értékeket kaptunk, mint az alatta elhelyezkedő két levélben.

A western blot eredményekkel kapcsolatban el lehet mondani, hogy az előkészítő kísérletek kapcsán említett jelenség itt is megfigyelhető volt, azaz a GS1-hez az antitest affinitása nagyobb volt mint a GS2-höz. A mért enzimaktivitásokkal párhuzamosan látható, hogy az izoenzimek mennyisége is hasonlóan változik. Az öntözött növényekben a zászlós levélben vannak a legnagyobb mennyiségben. A vízhiánynak kitett növényekben azt figyelhetjük meg a Plainsman V esetében a kalásztól számított harmadik levélben a GS2 
eltünik a levélből az öntözött kontrolhoz képest. A Cappelle Desprez esetében láthatjuk, hogy a szárazság hatására a zászlóslevélben tűnik el a plasztidikus izoenzim (GS2), míg a citoszólikus társa (GS1) megmarad. A kalásztól számított harmadik levélben a GS2 erős festődése jól látható és itt is lett mérve a legerősebb enzim aktivitás.
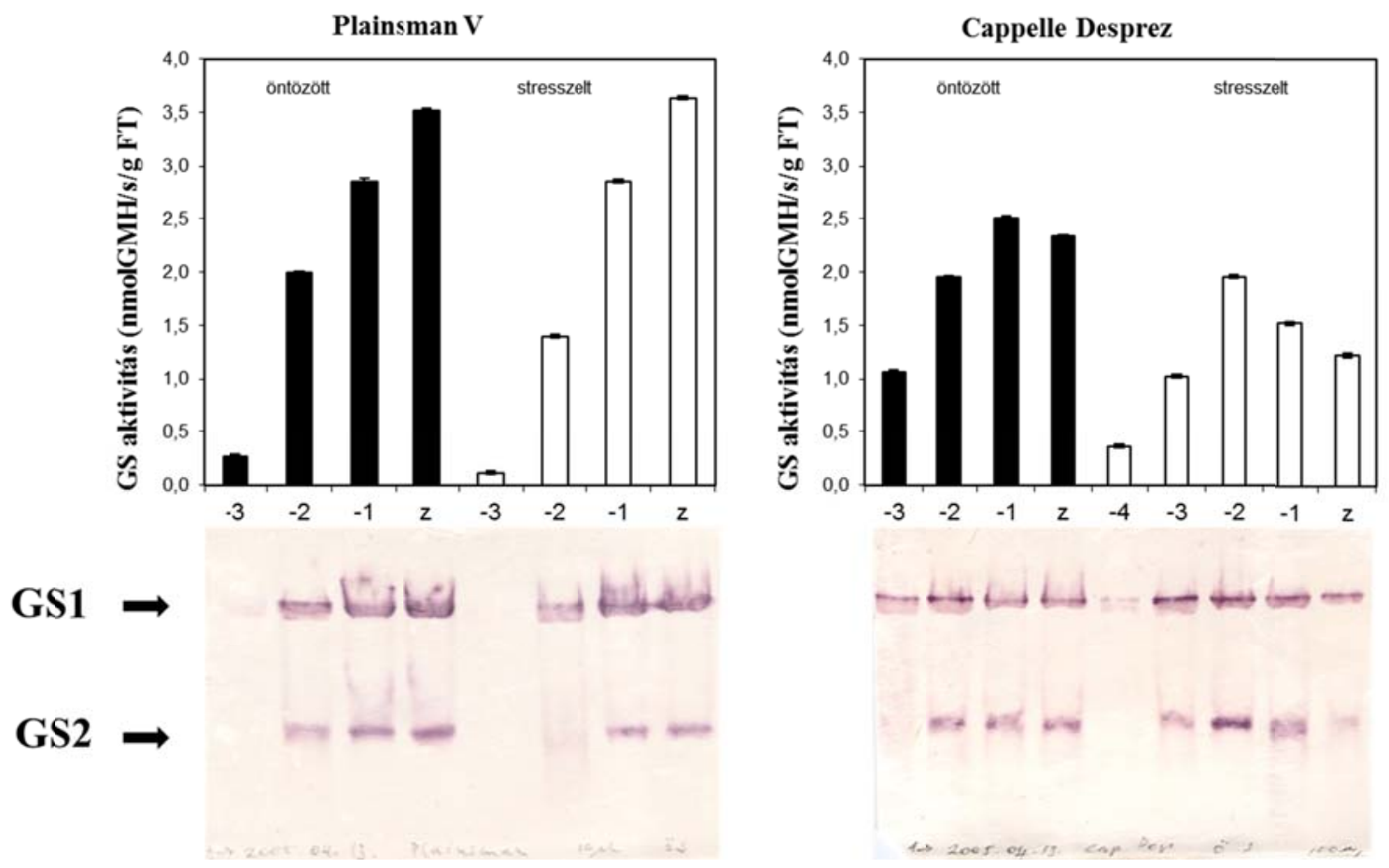

12. ábra: A Plainsman Vés Cappelle Desprez búza fajták kalász alatti négy levelének glutamin szintetáz aktivitása és az izoenzimek westernblot vizsgálatának eredménye a virágzás utáni kilencedik napon (DPA 9). A grafikonon $p \leq 0,01$-es szignifikancia szinten minden érték különbözö. A jelölt értékek három mérés átlagát és szórását mutatják. z: zászlóslevél -1, -2, -3: a zászlóslevél után következö levelek a gyökér felé

A 13. ábrán a további búza genotípusok szárazságra adott reakciója látható a glutamin szintetáz és a fehérje mennyiség vonatkozásában a kalász alatti két levélben. A korábbi és az itt látható eredmények alapján két csoportba sorolhatóak a búza fajták: az egyik csoportba azok tartoznak ahol a zászlóslevél a szárazságstressz alatt is magas GS aktivitással és magas fehérje tartalommal rendelkező, a másik csoportban pedig azok a fajták találhatóak, amelyeknél a vízhiány hatására a zászlóslevélben ezek az értékek alacsonyabbak lesznek mint a kalász alatti második levélben. Ezeknél a méréseknél is megfigyelhető az a jelenség, hogy a fehérje tartalom nagyságával azonos módon változik a 
glutamin szintetáz friss tömegre vonatkoztatott aktivitása. A Kobomugi tájfajta esetében azt a fajta jellegzetességet láthatjuk, hogy az öntözött növények esetében alig volt eltérés a kalász alatti levelek között mind fehérje tartalomban, mind GS aktivitásban.

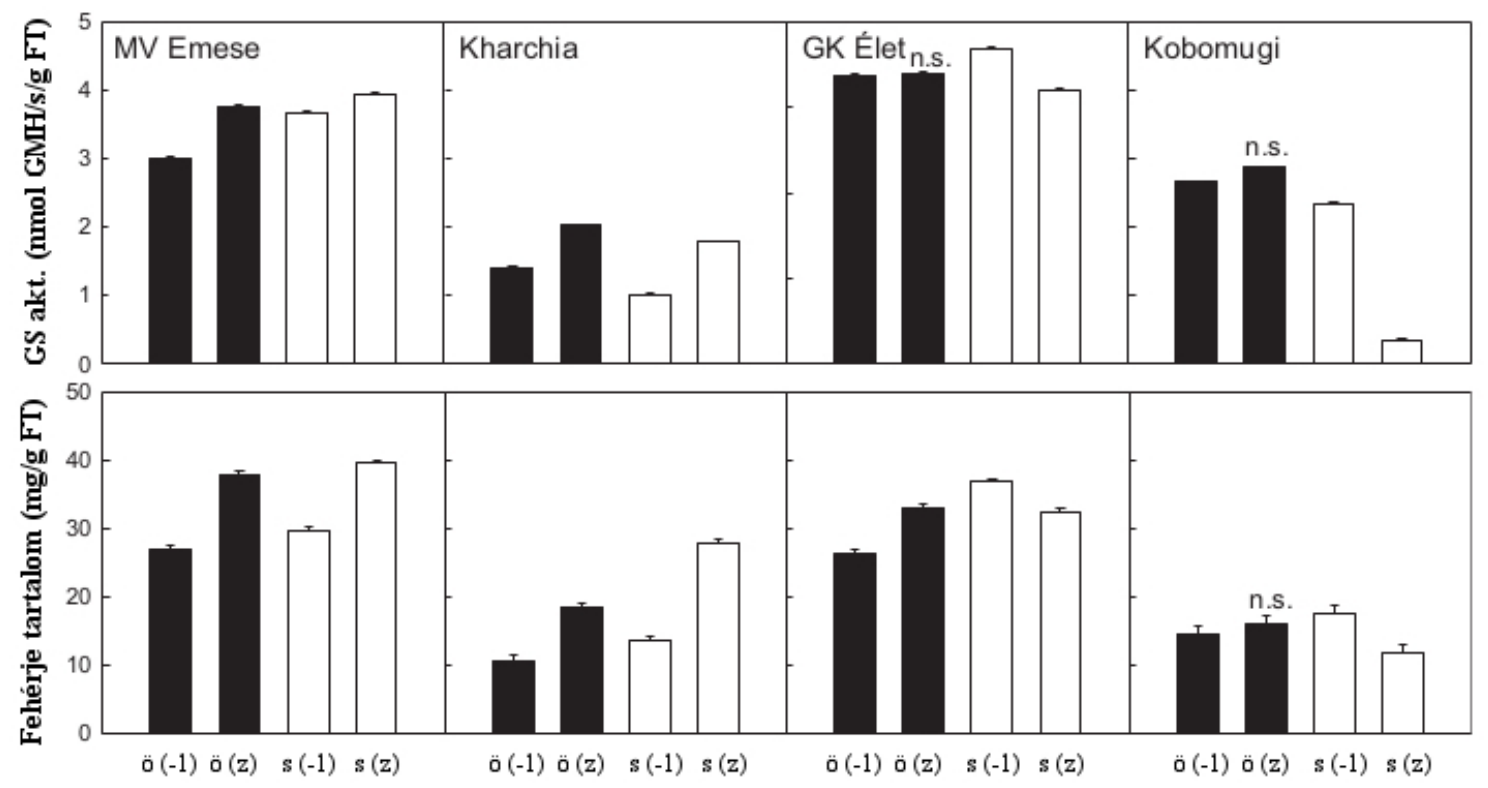

13. ábra: Az MV Emese, Kharchia, GK Élet és Kobomugi búza genotípusok friss tömegre vonatkoztatott glutamin szintetáz aktivitás változása és fehérjetartalom változása a kalász alatti két levélben öntözött (fekete oszlopok) és szárazságstressz (fehér oszlopok) alatt a virágzás utáni kilencedik napon (DPA 9). A grafikonon ahol nincs külön jelölve $p \leq 0,01$-es szignifikancia szinten az értékek különbözöek. A jelölt értékek három mérés átlagát mutatják z: zászlóslevél -1: a zászlóslevél alatti levél n.s.: nincs szignifikáns eltérés

Elmondható tehát hogy a Plainsman V, Mv Emese, Kharchia alkot egy csoportot, valamint a Cappelle Desprez, GK Élet és a Kobomugi tartozik a másik csoportba. Ezek a besorolások két eltérő élettani stratégia alkalmazására engednek következtetni szárazságstressz alatt 


\subsection{Alumíniumstressz}

\subsubsection{Alumínium hatása búzanövények növekedésére}

Az alumíniummal kapcsolatos vizsgálatok során elöször a fiatal, 2 hetes búza növények növekedésére gyakorolt hatását vizsgáltuk. Az eredmények a 14.-től a 17. ábráig láthatóak. Egyértelmủen megállapítható, hogy már alacsony koncentráción is $(10 \mu \mathrm{M})$ jelentősen gátlódik a gyökér növekedése alumínium-klorid kezelés hatására. Az ábrákon jól megfigyelhető az alumínium kezelés megkezdésének az időpontja is, ami a hetedik nap volt a csírázástól számítva. Ezt követően az eredmények elég nagy szórást mutatnak. Ennek feltételezhető oka, hogy a különböző növények, habár azonos genetikai háttérrel rendelkeznek mégis nagyon eltérő módon reagáltak a kezelésre, és egyes növények növekedése teljesen leállt vagy nem mutatott reakciót az alumínium kezelésre. Megfigyelhető, hogy magára a hajtás növekedésre nincs olyan drasztikus hatása ilyen rövid időintervallumban az alumíniumnak.

\section{Gyökér hosszúság}

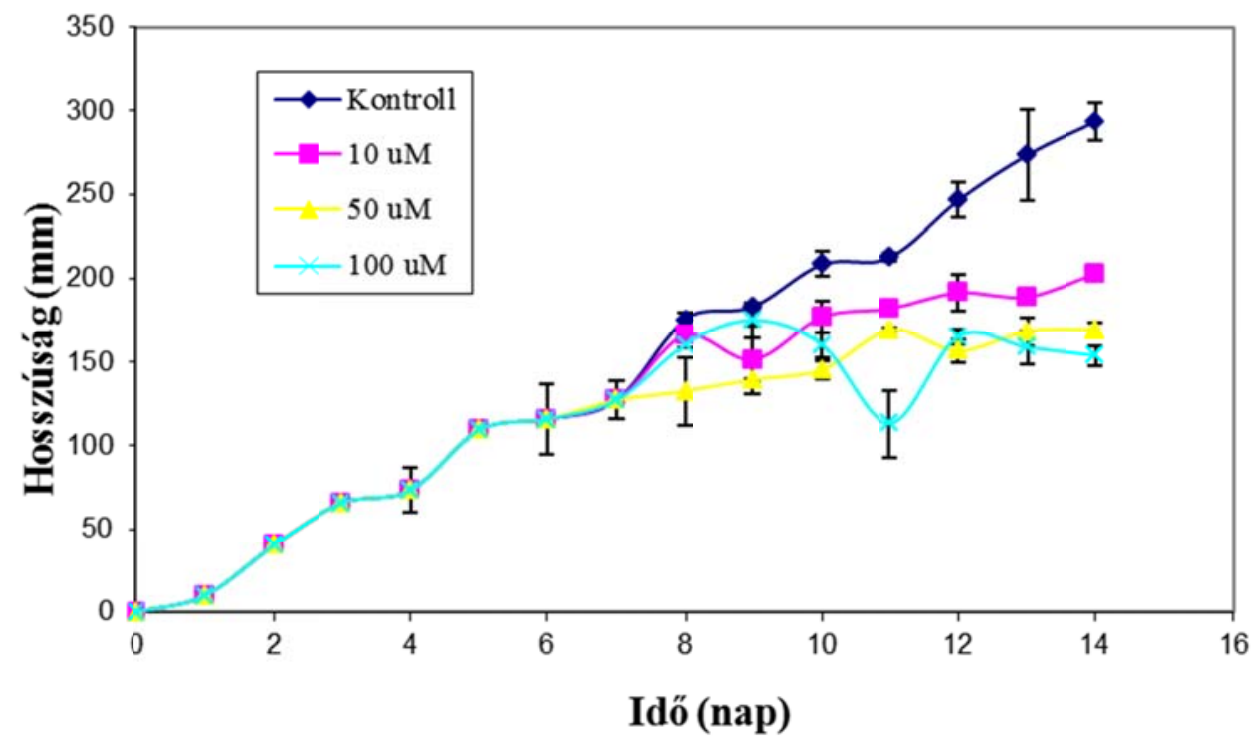

14. ábra: Különbözö koncentrációjú alumínium-klorid (0, 10, 50 és lo0 $\mu$ M) hatása a búzanövények gyökérhossz alakulására. A szignifikancia szint $p \leq 0,05$. A jelölt értékek négy mérés átlagát mutatják.

A 14. napon látszódik már a hajtáson is az alumínium növekedés gátló hatása. A gyökér fejlödésével kapcsolatban el lehet mondani, hogy az emelkedö koncentrációval nem csökken egyenes arányban a növekedés intenzitása. 
Hajtás hosszúság

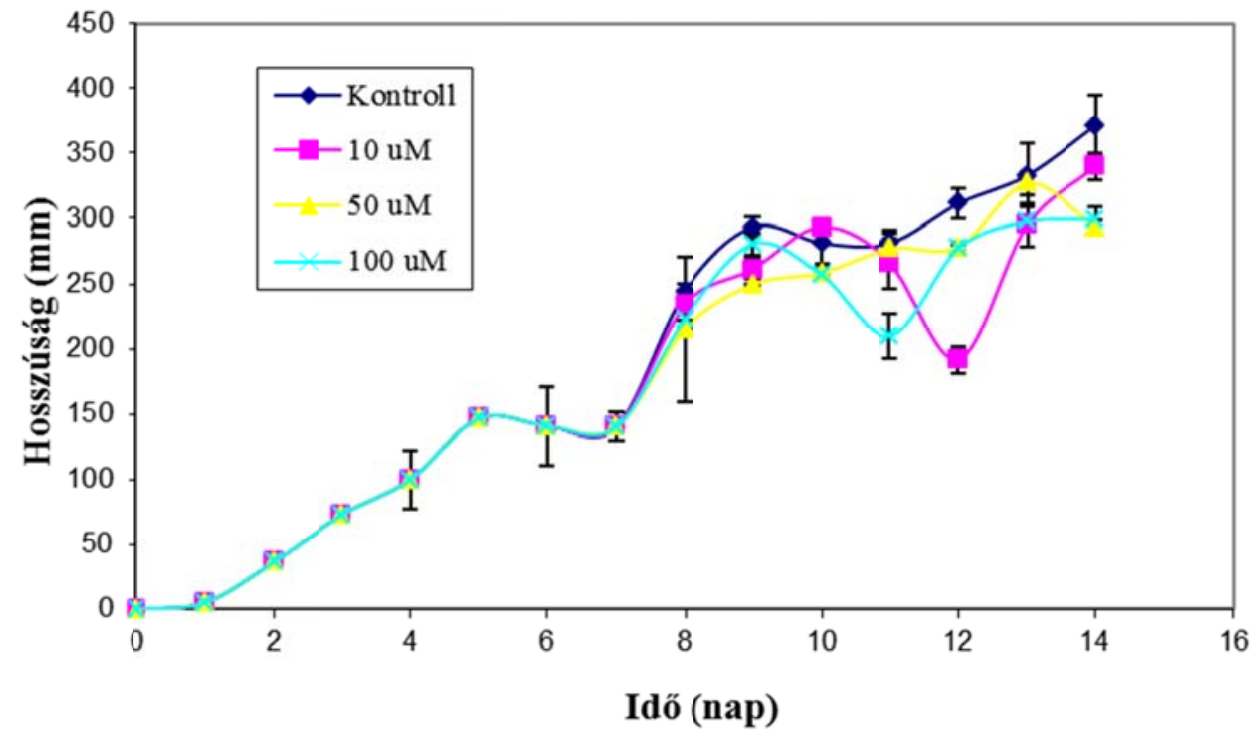

15. ábra: Különböző koncentrációjú alumínium klorid (0, 10, 50 és $100 \mu$ M) hatása a búzanövények hajtáshossz alakulására. A szignifikancia szint $p \leq 0,05$. A jelölt értékek négy mérés átlagát mutatják.

\section{Gyökér friss tömeg}

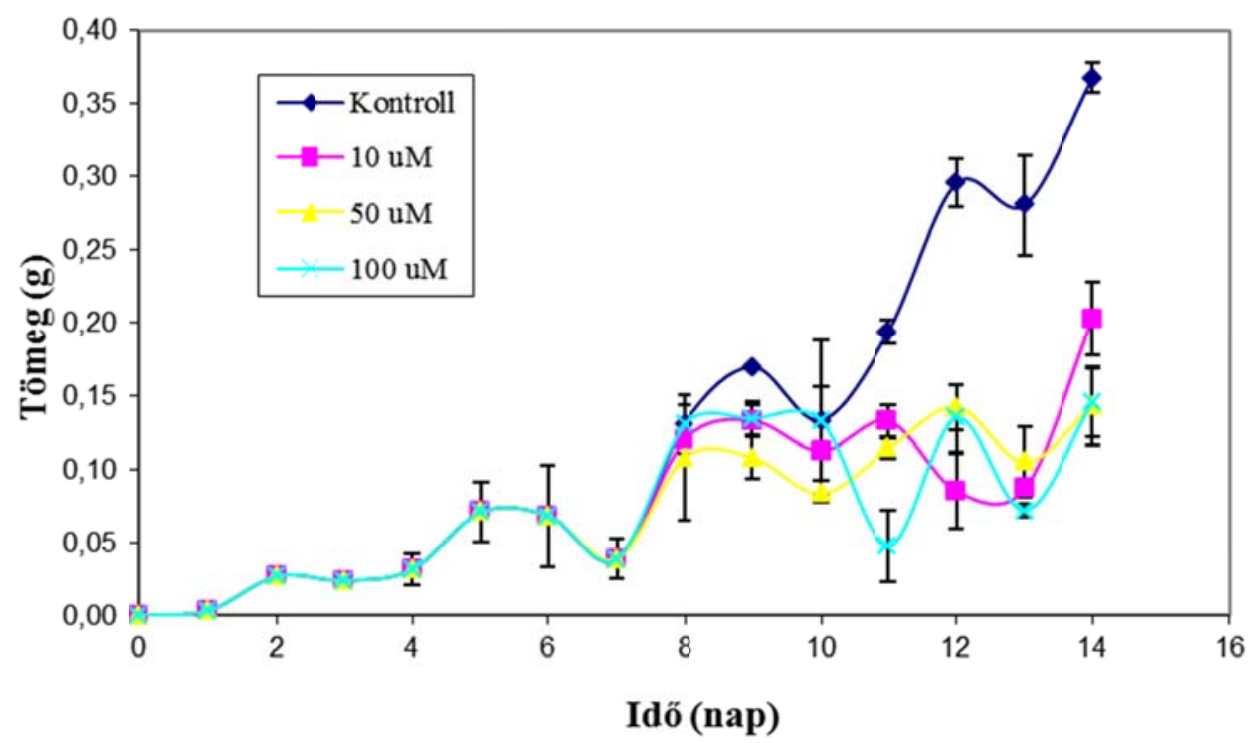

16. ábra: Különbözö koncentrációjú alumínium klorid (0, 10, 50 és $100 \mu M)$ hatása a búzanövények gyökér friss tömeg alakulására. A szignifikancia szint $p \leq 0,05$. A jelölt értékek négy mérés átlagát mutatják. 
Hajtás friss tömeg

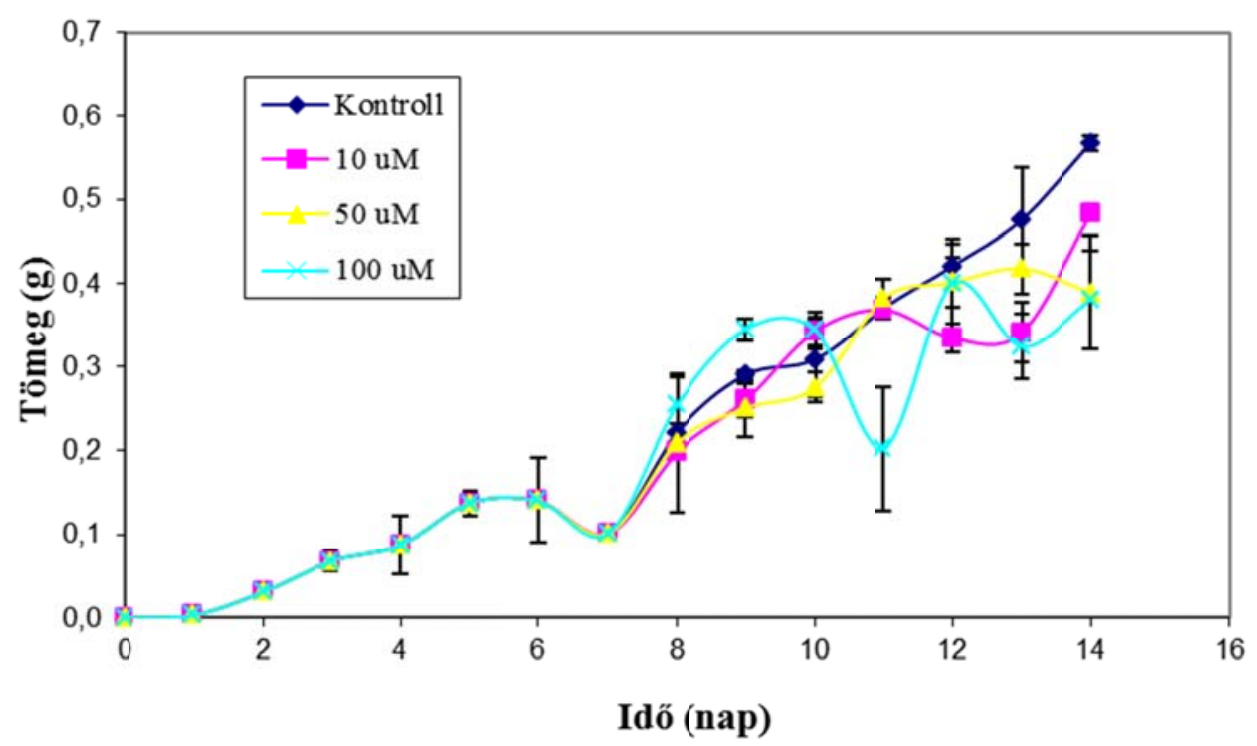

17. ábra: Különbözö koncentrációjú alumínium klorid (0, 10, 50 és $100 \mu M)$ hatása a búzanövények hajtás friss tömeg alakulására. A szignifikancia szint $p \leq 0,05$. A jelölt értékek négy mérés átlagát mutatják.

Ami a grafikonokból nem látszik, de a vizsgálatok során tapasztaltunk, hogy az alumíniummal kezelt növények gyökere rozsdabarna színezetü lett valamint tapintásuk érdes volt. Ennek oka a megvastagodott epidermisz szövet volt, ami a gyökereket ért fémstresszek egyértelmü jele a növényvilágban.

\subsubsection{Al(III)NTA hatása a GS aktivitására}

A szerves alumínium komplexek különbözőképpen hatnak a GS aktivitására. Az előzetes kísérletek során azt találtuk, hogy az Al(III)NTA komplex aktiválja leginkább a GS-t. (Lásd Kertész et al. 2002 és részletesebben az Eredmények értékelése címü fejezetben.) Ezért a kinetikai vizsgálatokhoz is ezt a komplexet használtuk, ahol 1:3 arányban volt az alumínium és a komplex képző az oldatban, így $10 \mu \mathrm{M}$-os volt az $\mathrm{Al}^{3+}$ koncentrációja. A kinetikai kísérletet eredményét a 18. ábra mutatja.

Ennél a kísérletnél a magnéziumiont szubsztrátként használtuk, az ATP és a hidroxilamin pedig feleslegben volt jelen a reakcióoldatban, azonban a magnézium 
koncentrációját mi állítottuk be. $\mathrm{A} \mathrm{Mg}^{2+}$-t azért lehetett szubsztrátnak tekinteni, mert a reakcióhoz elengedhetetlen a bivalens fémionok jelenléte és az enzim csak akkor képes tökéletesen müködni, ha a megfelelő mennyiségü fémion van jelen, valamint az enzim speciális fémkötő helye is az aktív centrumban helyezkedik el. A kapott szigmoid görbék is erre utalnak, ugyanis ezek megfelelnek a Michaelis-Menten féle kinetikának, ahol is a szubsztrát mennyisége szabja meg az enzim müködési sebességét egy bizonyos szubsztrát koncentráció alatt. Ha ugyanis kevesebb szubsztrát van jelen, mint amennyit fel tudna használni az enzim akkor nem éri el a maximális sebességét a fehérje (szuboptimális szubsztrát mennyiség). Azonban ahogy növeljük a szubsztrát mennyiségét úgy növekszik az enzim aktivitása is, de egy bizonyos szubsztrát koncentráció után már nem növekszik az enzim sebessége, ezt a sebességet nevezzük az enzim maximális sebességének, ekkor ugyanis több szubsztrát van már jelen, mint amit fel tud használni a fehẻrje.

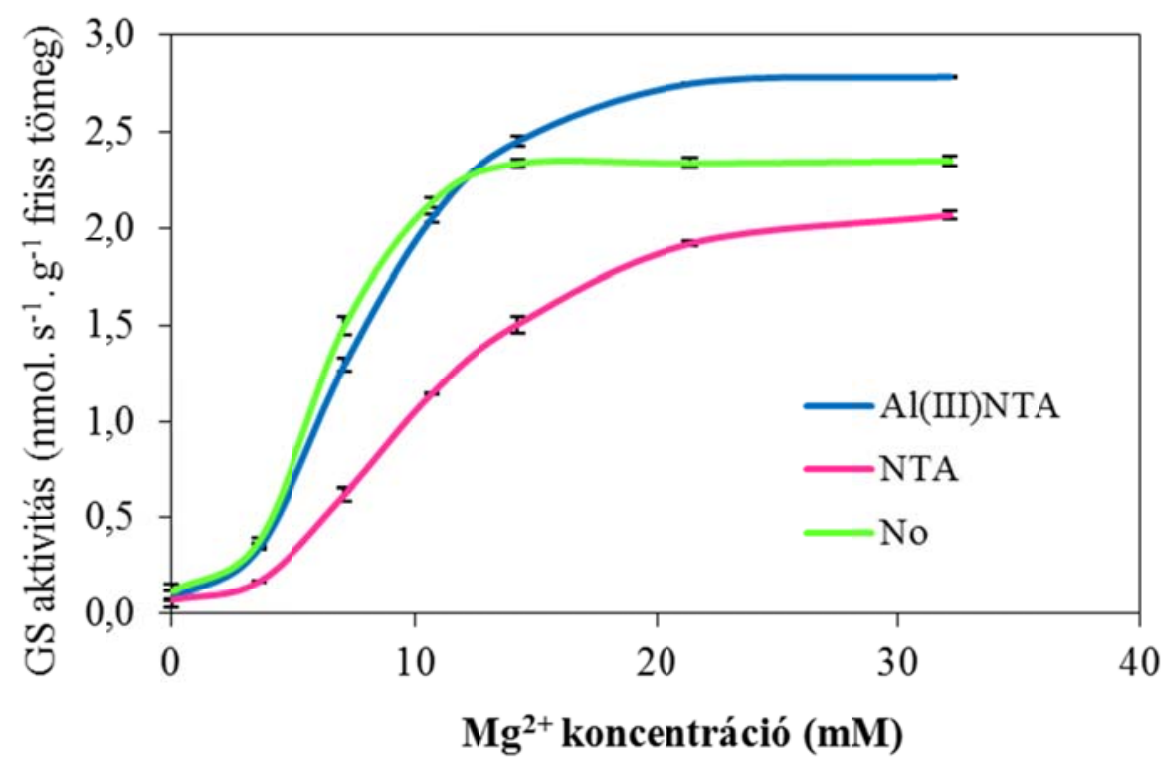

18. ábra: A glutamin szintetáz aktivitás változása Al(III)NTA komplex hatására növekvö magnézium ion koncentráció mellett. NTA: a nitrilo-triecetsavas kezelés. No: a desztvizes kezelést jelöli. A jelölt értékek három mérés átlagát mutatják.

Az enzimek maximális sebességét az szabja meg, hogy milyen gyorsan tud a szubsztrát az aktívhelyre kötni, valamint hogy a termék milyen gyorsan tud onnan leválni. 
Az egyes alegységeken lévő kötőhelyekre bekötő fémionoknak szerepe van a többi alegység aktiválásában is (alloszterikus hatás). A görbék szigmoid jellege a többalegységes felépítésre is utalnak. Az aktivitásnövekedést a keletkező termék (GMH) mennyiségével követtük nyomon. Az Al(III)NTA komplex aktiválja a GS-t növekvő magnézium koncentráció mellett, mégpedig a kezelés hatására kb. 35\%-kal növekszik meg a GS maximális sebessége. Az ábrán látszik, hogy a GS aktivitásához mindenképpen magnézium jelenléte szükséges: az alacsony $\mathrm{Mg}^{2+}$ koncentráció tartományban (szuboptimális) a kontroll és az Al(III)NTA görbék együtt futnak. Ha az alumínium magában is tudná aktiválni a GS-t akkor szuboptimális magnézium koncentrációnál is eltérne a két görbe futása. A szuboptimális $\mathrm{Mg}^{2+}$ koncentráció felett pedig az Al-komplex a kontrollnál magasabb aktivitást okoz, ami a magnézium koncentráció növekedése mellett is fennmarad. Ez azt mutatja, hogy a $\mathrm{Mg}^{2+}$ nem képes a GS fehérjéröl leszorítani az alumíniumot, az valószínüleg stabilan kötve marad az aktív állapotban a GS fehérjéhez. Ez, valamint az, hogy kis magnézium koncentrációnál sem nagyobb az Al(III)NTA komplexszel kezelt minta aktivitása, mint a kontroll mintáé, azt mutatja, hogy a magnézium és az alumínium nem kompetitívek. Ez arra utal, hogy az enzimben két féle fémkötő hely található melyek eltérnek fémion kötő képességükben, az egyiknek valószínűleg a magnéziumra nagy az affinitása, míg a másiknak az alumíniumra. Ha csak magában adunk NTA komplexképzőt a mintához, akkor csökken a GS aktivitása, azaz a GMH mennyisége, ez valószínűleg azzal magyarázható, hogy az NTA komplexet képez az oldatban lévő magnézium egy részével, így csökkenti a hatásos $\mathrm{Mg}^{2+}$ koncentrációt.

\subsubsection{Alumínium és magnézium mennyisége az Al(III)NTA-val kezelt GS-ben}

A fémionok mennyiségének meghatározásához a gélekböl a 19. ábrán látható, világos sávval jelölt, két helyről vettünk mintákat a poliakrilamid gélből.

A GS2-vel jelölt rész tartalmazta az Al(III)NTA-val kezelt vagy csak desztillált vízzel kezelt GS fehérjét, a kontroll sáv pedig egy számunkra semleges terület, aminek az ion tartalmához tudtuk viszonyítani a GS fémion tartalmát. Mind az alumíniummal, mind a desztillált vízzel kezelt minta esetében kb. 4 ml-nyi gélszeletet vizsgáltunk. Külön hangsúlyozni kell, hogy a fehérje kivonat kezelését a futtatás előtt végeztük, ez 20 perces inkubálást jelentett szobahőmérsékleten az alumíniumot tartalmazó reakciópufferrel. 


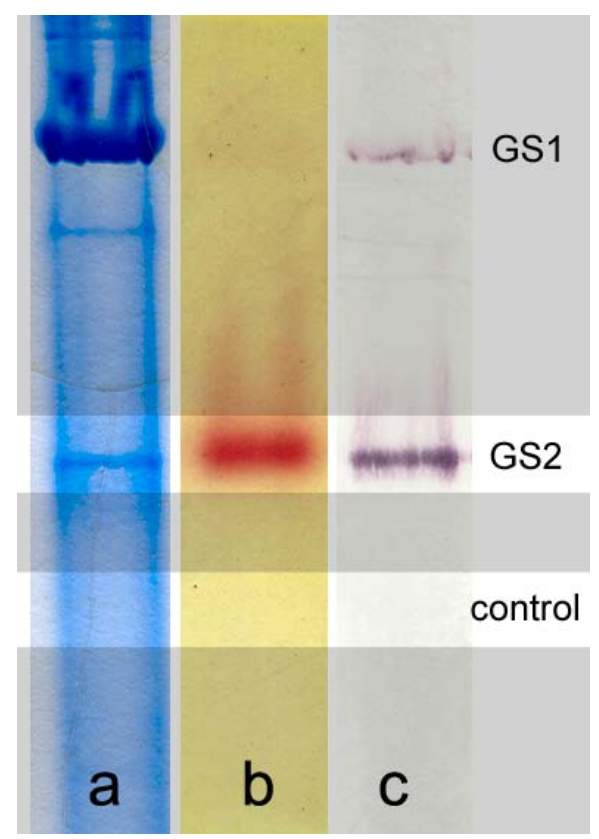

19. ábra: Elektroforetikus úton szeparált és kimutatott plasztidikus glutamin szintetáz egyhetes búza növény elsö leveléböl.

a: Coomassie G-250-vel festett poliakrilamid gél, b: GS aktivitás kimutatása gélben,

c. Western blot analízis eredménye

A 20. ábra mutatja a mintáink fémion mennyiségi és minőségi adatait. Látható, hogy a desztillált vízzel kezelt GS csak magnéziumot tartalmaz, alumíniumot nem. Az Al(III)NTA komplexszel kezelt GS kivonat esetében pedig az alumínium és a magnézium egyaránt kimutathatók. A 19. ábrán látható még a kontroll mintavétel helye is. A GS2 alatt lévő gélből vágtunk ki egy ugyanakkora sávot, mint a GS mintavétel esetén. A kontroll esetében csak annyi megkötésünk volt, hogy nyomokban se tartalmazzon GS fehérjéket. A kapott eredmények alapján azonban az is elmondható, hogy a kontroll gélszeletek magnéziumot és kezelések esetén alumíniumot sem tartalmaztak. 


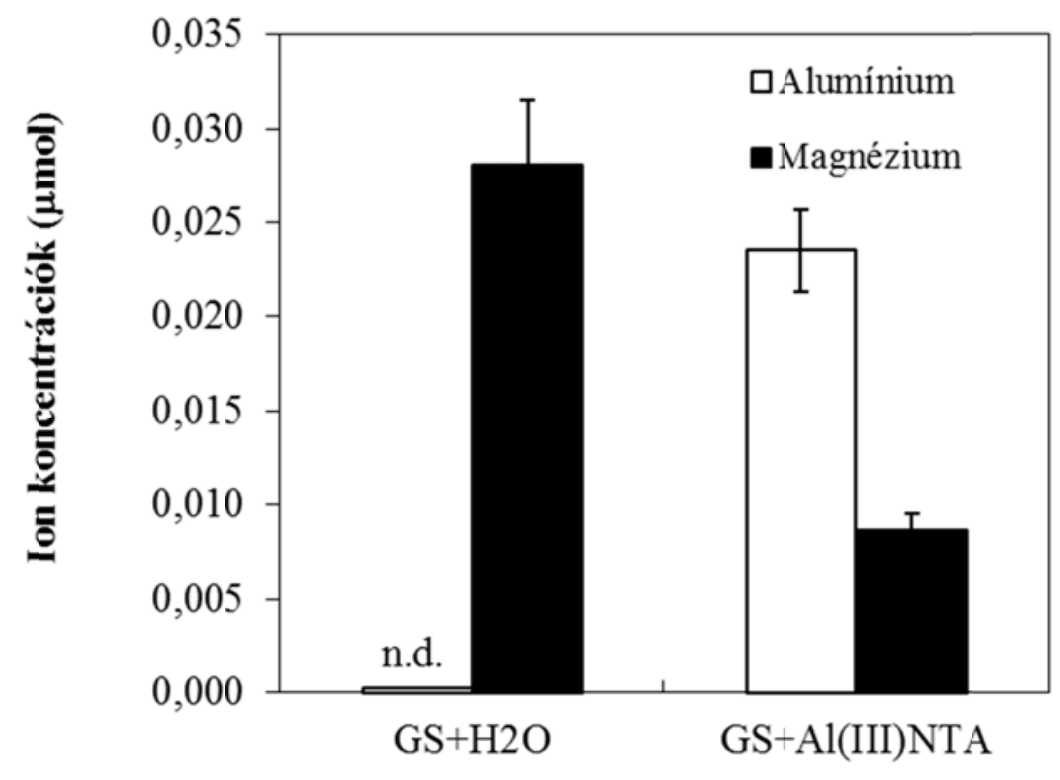

Kezelések

20. ábra: A glutamin szintetáz iontartalmának változása Al(III)NTA komplexszel való kezelés hatására. A jelölt értékek három mérés átlagát és azok szórását mutatja. Az n.d. azt jelöli, hogy a müszer nem érzékelt alumíniumot a mintákban.

Az alumínium kötődési helye az aktív centrumban, vagy ahhoz térben közel lévő helyen lehet. Erre két tény alapján is következtethetünk. Az első bizonyíték, hogy a GS aktivitása megváltozik, ez csak akkor történhet meg, ha az aktív centrumban történik változás, hiszen az enzimnek ez az aktivitásért felelős része. A második tényező, ami alátámasztja az $\mathrm{Al}^{3+}$ fémion specifikus kötőhelyre való kötődését, hogy az alumínium komplexszel való kezelés után a magnézium mennyisége csökken, míg az alumínium mennyisége nő a fehérjében, azaz a fémkötő helyeken a magnézium lecserélődik alumíniumra. A GS teljes fémion tartalma a kontroll és az Al(III)NTA-val kezelt minta esetében is közel azonos (21. ábra). 


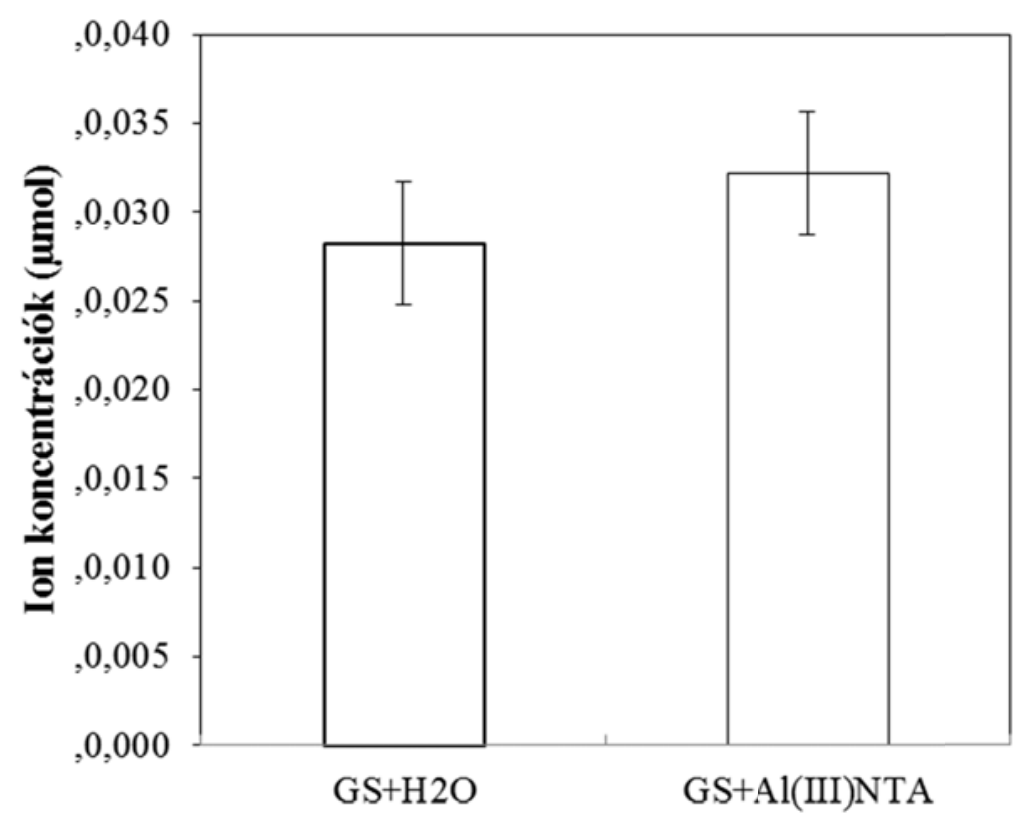

Kezelések

21. ábra: A teljes fémion tartalmak a hajtásban Al(III)NTA kezelés hatására. A jelölt értékek három mérés átlagát és azok szórását mutatja. Az értékek között szignifikáns eltérés nincs.

Valószínűsíthető ezért, hogy az alumínium a magnézium helyére kötődik be, de nem minden helyen, mivel marad magnézium is a fehérjében. Feltehetően, ha a GS elvesztené ezt a megmaradt kevés magnéziumot is, akkor alegységeire esne szét, azaz denaturálódna. Valószínüsíthetően a fehérje alegységeket összetartó magnézium ionok kötőhelye $(n 1)$ specifikusabb, mint az ATP kötéséért felelős fémionok kötőhelye (n2). Elmondható, hogy mindkét fémion kötődése stabil, hiszen a fémionok a gélfuttatási procedúra után is rajta maradtak a fehérjén. Ilyen stabil fémkötő helyek pedig a fehérje specifikus fémkötő helyei. A feltételezett két fémkötőhely részletesebb vizsgálata fényt deríthet azok eltérő voltára, de feltételezhetően az eltérő funkció miatt is más lehet a szerkezetük, de ez további vizsgálatot kíván, amihez már molekuláris biológiai módszerek szükségesek.

\subsubsection{In vivo eredmények}

Itt az in vivo kísérletek eredményeit közlöm, hogy bemutassam, hogy az in vitro mért értékek egyezést mutatnak az in vivo mért értékekkel. Tehát az általunk alkalmazott kísérleti módszerek és körülmények megegyeznek, vagy legalább is jelentősen nem térnek 
el az élő növényben található körülményektöl. Az in vivo kísérletekhez is egy hetes búzanövényeket használtunk, melyek 24 óráig voltak alumínium-kloridot tartalmazó tápoldatban. Ebben a kísérletben a növények eltérő alumíniumion koncentrációknak voltak kitéve.

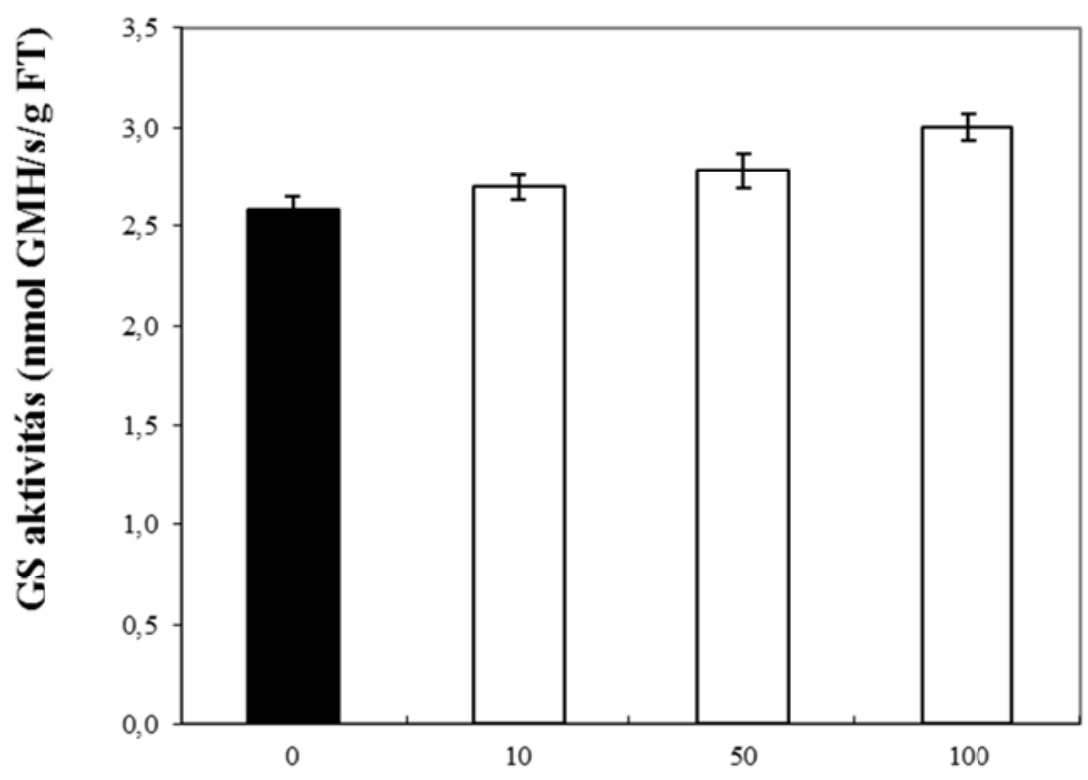

Al-koncentrációk $(\mu \mathrm{M})$

22. ábra: in vivo Al kezelés hatása a hajtásban található GS-ra. A jelölt értékek három mérés átlagát és azok szórását mutatja. Az 50 és $100 \mu M$-os kezelés $p \leq 0,05$ szignifikancia szint mellett eltérést mutat a kontroll kezeléstöl.

A 22. ábrán látható, hogy az egyhetes búzanövényekben a GS aktivitása megnövekszik az $\mathrm{AlCl}_{3}$ kezelés hatására. Tehát a növények reagáltak az alumínium komplex jelenlétére, mégpedig olyan módon, mint ahogy azt az in vitro kísérletben láttuk.

Annak bizonyítására, hogy a növényekbe ténylegesen bejut az alumínium, a növényeket súly állandóságig szárítottuk, majd ugyan csak ICP-AES technikával meghatároztuk azok fémion tartalmát. 


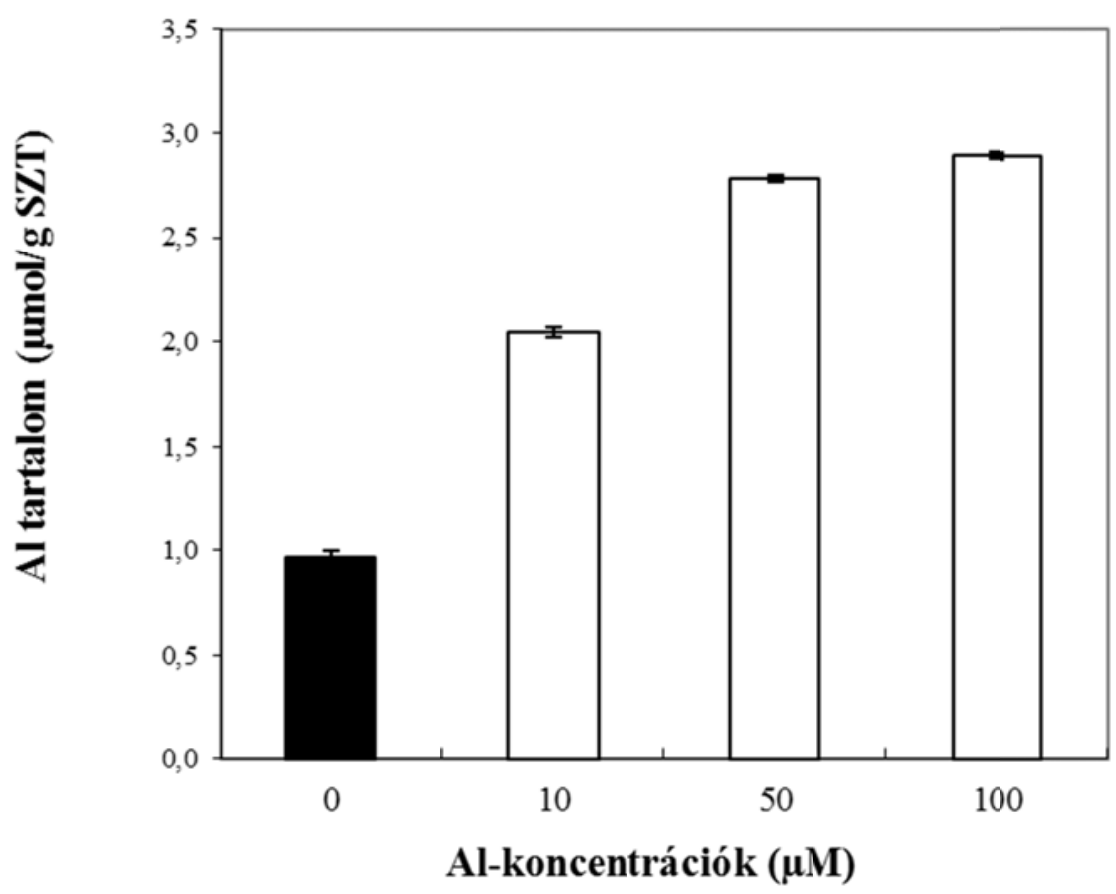

23. ábra: in vivo Al kezelt búzanövények hajtásának az alumínium tartalma. A jelölt értékek három mérés átlagát és azok szórását mutatja. A kontrollhoz képest mindhárom kezelés eltérést mutat $p \leq 0,001$ szignifikancia szint esetében.

23. ábrán láthatjuk a növények hajtásának az alumínium tartalmát. Már az alacsony $10 \mu \mathrm{M}$-os kezelés hatására is tapasztalunk a hajtásban Al felhalmozódást. Tehát az képes átjutni a búza növények sejtfalán és sejtmembránján. Megfigyelhető, hogy nincs lineáris kapcsolat az alkalmazott koncentráció és a szövetekben mért fémtartalom között. Ennek oka a különböző iontranszport folyamatokban keresendö. Elmondható tehát, hogy az alumínium nem passzívan kerül a növénybe, hanem feltehetőleg szabályozott müködésü ioncsatornákon, illetve a növényben található más ionok mennyisége is meghatározó lehet. További vizsgálataink során a magnéziumionnal való kapcsolatot is megnéztük. 


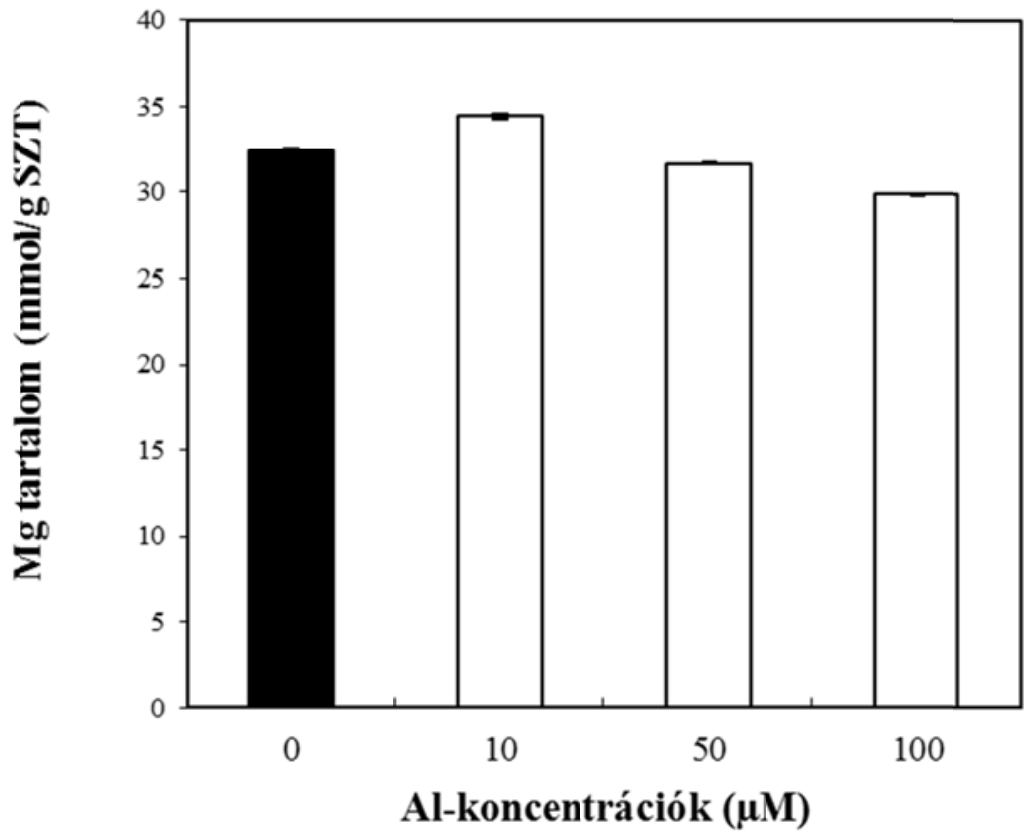

24. ábra: in vivo Al kezelt fiatal búzanövények hajtásának a magnézium tartalma. A jelölt értékek három mérés átlagát és azok szórását mutatja. A 10 és 100 M-os kezelés szignifikáns eltérést mutat a kontroll kezeléstöl $p \leq 0,05$ szignifikancia szintel.

A 24. ábrán a hajtások magnéziumion tartalma látható. $100 \mu \mathrm{M}$-os alumínium kezelés hatására, ha nem is jelentősen, de csökkent a magnézium tartalom. Ez az eredmény is összefüggésben áll az in vitro kísérletekkel, mivel a GS magnézium tartalma is csökkent a kezelés hatására. Feltehetőleg nem csak a GS magnéziumion tartalom változása játszik szerepet a hajtás fémion tartalom változásában, de mivel a hajtásban jelentős mennyiségben található plasztidikus glutamin szintetáz, így az enzim fémionkötő affinitása is szerepet játszhat a kialakult kisebb magnézium koncentrációnak. 


\section{Eredmények értékelése}

Kísérleteinkben arra kerestünk választ, hogy az abiotikus stresszhatások közül a vízhiány és az alumíniumstressz milyen hatással van a búzanövények nitrogén anyagcseréjében fontos szerepet betöltő glutamin szintetáz enzimre. Célunk volt, hogy a teljes GS illetve csak az egyes izoenzimek mennyiségi változásait nyomon kövessük. De ezekkel a vizsgálatokkal kapcsolatosan megnéztük a szén anyagcserében, a fotoszintézisben fontos Rubisco változásait is a szárazságstressz alatt, így keresve az összefüggést a szén és nitrogén metabolizmus változásai között. Az alumíniumstressz vizsgálataiban pedig külön figyelmet fordítottunk az enzim kinetikai változásaira és ezzel párhuzamosan a fémiontartalmára is. De meghatároztuk a növényi szervek alumínium és magnézium tartalmát is.

Munkánk során a vízhiányos körülmények között a kalászoló növényeket vizsgáltuk, míg az alumíniumstressz esetében pedig fiatal, egy-kéthetes növényeket. Mindegyik esetben a növények fehérjetartalmát megmértük, ezen kívül megvizsgáltuk a GS enzimaktivitását a levelekben, illetve natív poliakrilamid gélelektroforézissel és western blot-tal az izoenzimek mennyiségi változásait is. Az alumíniumstressz esetében pedig meghatároztuk a glutamin szintetáz fémion tartalmát ICP-AES technikával és szintén megmértük az enzimaktivitás változásokat és kinetikai görbéket is felvettünk.

\subsection{Szárazságstressz}

A mezőgazdasági termesztésbe bevont növények hozamának mennyiségi és minőségi alakulása nagyban függ azok stresszrezisztenciájától. Már nagyon hamar elkezdték szelektálni a nemesítők a növényeket a szárazságtürésre is. A leggyakoribb megfigyelt élettani tulajdonságok a következők: sztóma konduktancia, mely a gázcserenyilások nyitottságáról ad információt, a levélhőmérséklet, ami a párologtatással függ össze, fotoszintetikus kapacitás, korai érés, kései öregedés (stay-green), kukoricánál a pollen képzés és a bibe kíbújás közötti időtartam (ASI) esetében a rövidebb intervallum a kedvező, keményítő elérhetősége az embrió számára, gyökér hossz, stressz fehérjék akkumulációja (Cattivelli és mtsai. 2008). Ha ezeket a tulajdonságokat átnézzük, akkor láthatjuk, hogy ezek egy része a növény öregedésével van kapcsolatban. Egyébként nemcsak a direkt vízhiány van hatással ezekre a folyamatokra, hanem az ozmotikusstressz is, pl. $\mathrm{NaCl}$ kezelés is fehérje lebontást indukál, a nitrogén anyagcsere megváltozását okozza (Debouba és mtsai. 2006, Zhu és mtsai. 1998). 
Az aszály során a növények termésveszteségének hátterében a stressz indukált levélöregedés áll. A nagyon hamar meginduló levélsárgulás, leszáradás akadályozza a megfelelő szemfeltötltődést. A levelek, de főleg a zászlóslevél nitrogén tartalma, aminosav szintje, GS aktivitása meghatározó a szemfeltöltődés időszaka alatt. A növények nitrogén asszimilációja és reasszimilációja drasztikusan megváltozik a szeneszcencia során és ez komoly hatással van a termésbe jutó tápanyagok mennyiségére (Kichey és mtsai. 2006). A széndioxid megkötéséért felelős enzimek aktivitása lecsökken, de a különböző tápanyagok (elsősorban a makro tápelemek, aminosavak, cukrok) transzportjáért felelős folyamatok felerősödnek. A levél öregedési folyamata során az első megfigyelhető jelenség a fotoszintetikus aktivitás csökkenése és a kloroplasztisz degradációja (Noodén és mtsai. 1997). A kloroplasztisz nemcsak a fotoszintézisben résztvevő fontos sejtorganellum, hanem ebben a sejtszervecskében történik a megkötött nitrogén raktározása is. A növény össz nitrogéntartalmának 70-80\%-a van jelen a kloroplasztiszokban. A fotoszintetikus I. és II. rendszerek pigmentjei, fehérjéi körülbelül az kloroplasztisz összes nitrogén tartalmának 30\%-át adják, a Rubisco pedig több mint 50\%-át. De a ribulóz 1,5-bifoszfát karboxiláz/oxigenáz nemcsak a nitrogén anyagcserében játszik szerepet, hanem természetesen a széndioxid megkötése által a szén anyagcserében is (Evans 1989, Makino és Osmond 1991).

A levél fejlődése több fázisra osztható. Az asszimiláló szakaszából az öregedés szakaszába való belépés azonban csak néhány évtizede kutatott terület. Arabidopsisban írtak le korán öregedő (sárguló levelü, ún. „leaf-yellowing”) egyedeket. Ezek a vonalak magas fehérje és szabad aminosav szinteket mutattak a vad típusokhoz képest. A szeneszcencia kezdő lépése minde esetben a fehérje degradáció növekedése, ami együtt jár a citoplazmatikus glutamin szintetáz izoenzim (GS1) és a glutamát dehidrogenáz (GDH) génjeinek expressziójával és ezek enzimaktivitásának növekedésével (Diaz és mtsai. 2008, Masclaux és mtsai. 2000). Arabidopsisban az öregedő rozetta levelekben már leírták a citoszólikus és a plasztidikus glutamin szintetáz eltérő génexpresszióját. A GS2 mennyisége lecsökkent, de a GS1 megmaradt, vagy kismértékben emelkedett (Bernhard és Matile 1994).

A szeneszcenciális kloroplasztisz degradáció egyszikü növényekben mindig az alsó, legidősebb, levelekben kezdődik és utoljára a zászlós levél lép be az öregedési folyamatba (Wiedemuth és mtsai. 2005). Ennek során megkezdődik a színtestek lebontása. A kloroplasztisszal ellentétben a mitokondrium a levél öregedés legvégső szakaszáig 
teljesen intakt marad (Smart 1994). A fehérjék és klorofill molekulák enzim rendszerek (például endopeptidázok által) által szabályozott lebontása megy végbe a kloroplasztiszok degradációjakor (Yamauchi és mtsai. 2002). Kísérleteinkben a Rubisco mennyiségi változásait is nyomon követtük. Az eddigiek alapján elmondható, hogy az összes oldott fehérje koncentráció csökkenése és a nitrogénanyagcsere egyes enzimeinek (pl. glutamin szintetáz) állapota megfelelő indikátora a levélöregedésnek.

A szakirodalomban nagyon kevés az olyan vizsgálat, ahol az egymás alatt lévő levelek állapotát hasonlítják össze egy-egy stressz folyamatban, legtöbbször csak a zászlós levél állapotát vizsgálják. Ebből a szempontból munkánk hiánypótló a növényi stresszélettan területén. Figyelmet fordítottunk arra, hogy a két nemzetközi fajta esetében (Plainsmann $V$ és Cappelle Desprez) a kalász alatti négy levelet, a többi genotípus esetben pedig a kalász alatti két levelet vizsgáltuk és hasonlítottuk össze. Ezzel a szekvenciális öregedési mintázat változásait követtük nyomon kontroll és vizhiányos körülmények között. Belső szignálok, úgy mint a növényi hormonok megváltoztatják a metabolikus folyamatokat és a ,sink-source” viszonyokat, azaz a tápanyag szállítási tendenciákat, aminosavak, cukrok eloszlását, a növényi szervezetben. Számos publikáció foglakozik a megváltozott hormonszintekkel, fotoszintetikus aktivitás változásokkal, szénhidrát tartalom változással és speciális szignál molekulák jelenlétét is detektálták az öregedés folyamatában, mint például a reaktív oxigén gyökök (Wiedemuth és mtsai. 2005). Az általunk vizsgált növényeken megtörtént a levelek relatív víztartalmának mérése, a gyökér és hajtás abszcizinsav és malondilaldehid tartalmának meghatározása, illetve bizonyos gének expressziós változásainak detektálása más kutatók által is (Csiszár és mtsai. 2012, Gallé és mtsai. 2009, Guóth és mtsai. 2009 és 2010, Sečenji és mtsai. 2010, Tari és mtsai. 2010).

Munkánk során a glutamin szintetáz aktivitásbeli és mennyiségi változásait követtük nyomon öntözött és vízhiányos körülmények között a kalászoló búzanövény különböző levélemeletein. A vizsgált élettani időszak a virágzás utáni kilencedik nap volt. Ekkor a levelekben már megindulnak az öregedési folyamatok, illetve ez a szemfeltöltődésnek is az időszaka. A GS kloroplasztiszban és a citoszolban elhelyezkedő izoenzimjeinek változását is megnéztük, valamint ezzel párhozamosan az összes oldott fehérje koncentrációt és Rubisco mennyiséget is megvizsgáltuk. 
A virágzás utáni öregedési folyamatok az öntözött növényeknél is megfigyelhetőek voltak. A legfiatalabb zászlóslevéltől a legidősebb alsó levélig fokozatosan csökkent a fehérje tartalom, ezzel párhuzamosan a Rubisco tartalom is. A glutamin szintetáz aktivitások is a szeneszcencia előrehaladásával csökkent. A western blot vizsgálatok is először a kloroplasztisz degradálódását mutatták ki, ugyanis a plasztidikus GS2 izoenzim mennyisége csökkent, majd tünt el teljesen az alsóbb, öregebb levelekből. A citoszólikus GS1 mennyisége nem csökkent, sôt kismértékü növekedését is tapasztaltunk. Ez alapján elmondhatjuk, hogy a két izoenzim eltérő szabályzás alatt áll. Az itt leírtak megfelelnek az egyszikűeknél általánosan leírt szekvenciális szeneszcenciának (Wiedemuth és mtsai. 2005). Amit fontos kiemelni, hogy öntözött körülmények között mindegyik búza genotípus esetében ezt az öregedési mintázatot figyeltük meg. Az egyes levelek eltérő időben, de egymás után, szabályos sorrendben léptek be a degradációs folyamatba. Annyi különbséget találtunk a fajták között, hogy a Plainsman V, Mv Emese és Kharchia esetében fehérje koncentráció és a glutamin szintetáz aktivitás csökkenése meredekebb volt a többi fajtához képest.

A növények között egyértelmü eltérés mutatkozott a szemfeltöltődési időszak alatt vízhiány hatására. Szakirodalom alapján tudjuk, hogy a búza végső hozam paramétereit jelentősen befolyásolja ilyenkor a szélsőséges környezeti paraméterek (Barnabás és mtsai. 2008). Az is elmondható, hogy a vízhiány indukált levélszeneszcenciát az ABS szint emelkedése és Cys-protein kinázok megjelenése indítja be (Pic és mtsai. 2002).

A kalászoló búzák relatív víztartalma 10-15\%-kal csökkent a szenzitív és toleráns genotípusokban is a szárazságstressz hatására (Gallé és mtsai. 2009). Ahogy a növények állapotán is látszott már a virágzás utáni kilencedik napon, úgy a kalászban lévő szemszám, szemtömeg és ezerszem tömeg is csökken a szenzitívként leírt genotípusokban (Guóth és mtsai. 2009). A vízhiány során a Plainsman V fajta sokkal nagyobb zöld felülettel rendelkezett, mint a Cappelle Desprez. A zászlóslevelek is a vizsgálat napján zöldebbnek mutatkoztak a rezisztensnek tartott fajtákban. Ez a „stay-green” állapot meghatározó a termésmennyiség szempontjából. Minél tovább marad zöld a zászlós levél, annál több tápanyagot képes a kalászban lévő magokhoz eljuttatni. A késleltetett szeneszcencia és a megnövekedett nitrogén asszimiláció között a kapcsolat egyértelmü. Mind a termés mennyiség és stabilitás nagyobb szárazságstressz alatt is a tovább zölden maradó növényekben (Bäzinger és mtsai. 2002, Royo és mtsai. 2004). Durum búza esetében a késletetett öregedést mutató mutánsok esetében 10-12\%-kal nagyobb 
szemtömeget mértek, bár nem mindegyik mutánsnál mutattak ki magasabb nitrogéntartalmat is (Spano és mtsai. 2003). A többi fajtánál is megfigyelhető volt ez a fenotípus változatosság. A szárazságstressz alatt két eltérő öregedési folyamatot figyeltünk meg. A Cappelle Desprez, GK Élet, Kobomugi esetében nem szekvenciális öregedést tapasztaltunk. A zászlóslevelekben hamarabb megindult a fehérje degradáció, mint a kalász alatti második levélben. Ezzel párhuzamosan a Rubisco mennyisége is csökkent. A normális öregedési sorrend felborult. A toleránsnak leírt fajtáknál (Plainsman $\mathrm{V}, \mathrm{Mv}$ Emese) és a Kharchia tájfajtánál azonban nem láttunk számottevő eltérést a vízhiány hatására. A szekvenciális öregedést mutatták a levelek és ennek megfelelően alakultak a fehérje koncentráció és GS aktivitás változások is. A zászlóslevél maradt a legtovább asszimiláció képes. Ezt a fotoszintetikus aktivitási adatok mellett a kloroplasztisz állapotáról jó információt adó magas GS2 mennyiség és magas enzimaktivitás is alátámasztja. Összességében elmondható, hogy ebben az esetben adaptálódtak a növények a vízhiányos körülményhez.

A vízhiányra szenzitívnek leírt fajták esetében a menekülő stratégia jeleit fedeztük fel. Az alkalmazkodás jeleit nem láttuk, hanem csak egy nagyon felgyorsult zászlóslevél öregedést tapasztaltunk. A fajták közül valamennyire kilóg a sorból a félsivatagi klímán élő, belső ázsiai eredetű Kobomugi. Azt várnánk, hogy teljes mértékben egy adaptálódott genotípussal van dolgunk, de mégis a levélöregedési folyamatok hasonlítanak a szenzitív fajtákban megfigyeltekre. Söt az egész növény nagyon gyors elszáradása jellemezte, életciklusát jelentősen lerövidítette és csak néhány magot érlelt a kisméretü kalászban. A GS aktivitás is nagyobb mértékben csökkent a többi búzafajtához hasonlítva. El lehet mondani, hogy az „escaper” stratégia jó mintapéldánya a Kobomugi. De más vizsgálatok alapján tudjuk, hogy fokozott gyökér növkedést is mutat vízhiány hatására, illetve a sztómazáródási tulajdonságai is inkább „elkerülő” stratégiát alkalmazó fajtákra hasonlít (Erdei és mtsai. 2002, Gallé és mtsai. 2002). Elmondható, hogy a Kobomugi több szempontból is rendhagyó viselkedést mutató és további kutatásokat igénylő genotípus.

A két eltérő szárazság indukált öregedési folyamat hátterében összetett élettani folyamatok állnak. Az eltérő hormon szintek, különböző gének kifejeződései felelősek az adaptációért és az öregedés folyamatban lezajló programozott sejtdegradációért, sejthalálért. A Plainsman V és Mv Emese esetében vízhiány hatására az abszcizinsav szint megemelkedik a zászlóslevelekben és a szemtermésben. Először a zászlós levél ABS 
szintje nő meg a kalászhasban állapot alatt, majd lecsökken a kalász érésével párhuzamosan. A Cappelle Desprez és GK Élet azonban még a meglévő ABS szint is csak tovább csökken a levélben, az öntözött és vízhiánynak kitett növények abszcizinsav változása között minimális eltérés volt, ugyan azt a tendenciát mutatták. Tehát megfigyelhető, az a jelenség, hogy drasztikus ABS szint változás a levél zölden maradását eredményezi, míg az állandó szinten maradó, nem növekvő abszcizinsav koncentráció pedig a levél öregedésével jár együtt. A mi eredményeink alapján elmondható, hogy a fehérje degradáció megelőzéséhez is szükséges a megfelelő abszcizinsav jelenlét. A Kobomugi menekülő stratégiája más vizsgálatok kapcsán is megmutatkozott. Az ázsai sztómazáródása a stresszre adott válaszként sokkal hamarabb jelentkezett, mint a Plainsman V-ben, de a klorofill fluoreszencia vizsgálatok alapján mégis azt lehet mondani, hogy a fénystressznek ellenállóbb (Gallé és mtsai. 2002).

A fenti eredmények tükrében elmondható, hogy a levelek teljes fehérje koncentrációja, a Rubisco mennyisége, a glutamin szintetáz aktivitása és a GS izoenzimek aránya jó indikátora a növények szárazságstressz elleni stratégiájának. A lebontási folyamatok miatt csökkenő fehérje és Rubisco mennyiség, a GS2 izoenzim eltűnése, illetve a GS1 növekedése mind a gyorsuló szeneszcenciára mutató jelek. A gyorsuló öregedés azonban nem egyformán jelentkezett minden genotípusban. Az adaptációra képes fajtákban a megmaradt a szekvenciális öregedésre jellemző, a gyökértől a kalász irányába mutató, levél elszáradás. De a vízhiányra érzékenyebb fajták esetében az öregedés a zászlóslevelekben annyira felgyorsul, hogy hamarabb transzportálódik onnan tápanyag a kalászba (növekvő GS1 mennyiség), mint az alsóbb levelek. A kalászban hamarabb megtörténik a szemek érése. Szaporodásbiológiai szempontból ez sem rossz stratégia, hiszen csíra magok jönnek létre, de az ezerszem tömeg és a kalászban lévő magok száma elmarad a hosszabb ideig asszimilálni képes fajtáknál mért adatoknál (Guóth és mtsai. 2009).

\subsection{Alumíniumstressz}

\subsubsection{Különböző szerves savak alumínium komplexeinek hatása a GS aktivitására}

Az alumínium a talajásványok egyik leggyakoribb alkotóeleme. (Delhaize és Ryan 1995) A talajoldatban is jelen van különböző speciációkban. A fitotoxicitása ezeknek az eltérő vegyértékű és kötésállapotú formáknak ( $\mathrm{Al}^{3+}$, mononukleáris, polinukleáris) egyértelmü, bár a fiziológiai károsító hatásuk mértéke eltérő (Kinraide, 1990). Az $\mathrm{Al}_{13}$ 
polinukleáris forma rhizotoxicitása tízszer nagyobb mint az $\mathrm{Al}^{3+}$-é (Delhaize és Ryan 1995, Kochian és mtsai. 2005, Matsumoto 2000). A növény számos élettani folyamatot müködtethet az alumínium formák semlegesítésére (Kochian és mtsai. 2005). A belső tolerancia mechanizmusok kelát képzésen és a karboxilát anionokkal való detoxifikációval történik meg a szimplasztban (Barlett és Riego, 1972). A citromsavat találták a legjelentősebb kelátorának az $\mathrm{Al}^{3+}$-nak (Miyasaka és mtsai. 1991, Yang és mtsai. 2000).

Búzában ezenkívül megfigyelték az almasavat fokozott termelését az alumínium rezisztens genotípusokban (Basu és mtsai. 1994). De más szerves savak szerepét is meghatározónak tartják az alumínium detoxifikálásában (Ma és Furukawa 2003, Quartacci és mtsai. 2005 és 2007). Az általunk vizsgált szerves savak kiválasztása is ezen szakirodalmak alapján történt.

Az 5. táblázatban a Szegedi Tudományegyetem Növénybiológiai Tanszékén korábban (Kertész és mtsai. 2002) és az általunk is vizsgált különbözö szerves savak alumíniummal képzett komplexeinek speciációinak eloszlása látható. Egyes elemek különböző vegyérték- és kötésállapotú formáit az elem speciációinak nevezzük. Egy adott elem toxikus vagy esszenciális hatását a biológiában sosem magához az elemhez köthetjük, hanem annak különböző összetételű komplexéhez. Az egyes speciációjú komplexeknek egymástól jól elkülönülő fizikai, kémiai és ezáltal biológiai tulajdonsága van, ami meghatározza toxicitásukat. Az 5. táblázat egyes celláiban az alumíniumnak ezeket a különböző speciációit láthatjuk az egyes komplexekben.

A szakirodalom alapján tudjuk, hogy a növények sokféle szerves savat kiválasztanak a gyökérzónában. A talaj savasodásával ezek különböző komplexeket hoznak létre az ott kioldódó fémionokkal. Az itt feltüntetett összetételek egyértelmü összefüggésben állnak a vegyületek élettani hatásaival, toxicitásával. A mi kísérleteinkben a glutamin szintetáz kinetikai változásai alapján követtük nyomon az egyes komplexek közötti különbségeket. 


\begin{tabular}{|c|c|c|c|c|c|c|c|c|c|c|c|}
\hline Ligand & Tejsav & $\begin{array}{c}\text { Borkö- } \\
\text { sav }\end{array}$ & IDA & $\begin{array}{c}\text { Alma- } \\
\text { sav }\end{array}$ & $\begin{array}{c}\text { Malon } \\
\text {-sav }\end{array}$ & $\begin{array}{c}\text { Citrom } \\
\text {-sav }\end{array}$ & NTA & $\begin{array}{c}\text { Oxál- } \\
\text { sav }\end{array}$ & $\begin{array}{l}\text { Szacha } \\
\text { rát sav }\end{array}$ & EDTA & $\begin{array}{c}\text { NTA } \\
3 \mathrm{P}\end{array}$ \\
\hline \multicolumn{12}{|c|}{$\begin{array}{c}\text { Koncentráció } \\
(\mathrm{mol} \%)\end{array}$} \\
\hline AlAH & & & & & & & & & & & $\begin{array}{l}1.23 \\
(-2)\end{array}$ \\
\hline AlA & & & & & & & & & & $\begin{array}{l}99.8 \\
(-1) \\
\end{array}$ & $\begin{array}{l}22.9 \\
(-3) \\
\end{array}$ \\
\hline $\mathrm{AlA}_{2}$ & & & & & $\begin{array}{l}10.4 \\
(-1)\end{array}$ & & & & & & \\
\hline $\mathrm{AlA}_{3}$ & & & & & $\begin{array}{c}36.6 \\
(-3)\end{array}$ & & & $\begin{array}{l}56.8 \\
(-3)\end{array}$ & & & \\
\hline $\mathrm{AlAH}_{-1}$ & & & $\begin{array}{l}8.7 \\
(0) \\
\end{array}$ & & & & $\begin{array}{l}89.7 \\
(-1)\end{array}$ & & & & $\begin{array}{l}75.9 \\
(-4) \\
\end{array}$ \\
\hline $\mathrm{AlAH}_{-2}$ & & $\begin{array}{l}48.2 \\
(-1) \\
\end{array}$ & $\begin{array}{l}91.1 \\
(-1) \\
\end{array}$ & & $\begin{array}{l}29.7 \\
(-1) \\
\end{array}$ & $\begin{array}{l}7.31 \\
(-2) \\
\end{array}$ & $\begin{array}{l}9.61 \\
(-2) \\
\end{array}$ & $\begin{array}{l}20.3 \\
(-1) \\
\end{array}$ & & & \\
\hline $\mathrm{AlAH}_{-3}$ & $\begin{array}{l}47.7 \\
(-1) \\
\end{array}$ & $\begin{array}{l}33.3 \\
(-2)\end{array}$ & & & & & & & $\begin{array}{l}11.2 \\
(-2)\end{array}$ & & \\
\hline $\mathrm{AlA}_{2} \mathrm{H}_{-1}$ & & & & & & $\begin{array}{l}15.7 \\
(-4)\end{array}$ & & $\begin{array}{l}21.4 \\
(-2)\end{array}$ & & & \\
\hline $\mathrm{AlA}_{2} \mathrm{H}_{-2}$ & & & & & & $\begin{array}{l}15.4 \\
(-5)\end{array}$ & & & & & \\
\hline $\mathrm{Al}_{2} \mathrm{AH}_{-3}$ & & & & $\begin{array}{c}100.0 \\
(+1)\end{array}$ & & & & & & & \\
\hline $\mathrm{Al}_{2} \mathrm{~A}_{2} \mathrm{H}_{-4}$ & & $\begin{array}{l}16.6 \\
(-2)\end{array}$ & & & & & & & $\begin{array}{l}98.8 \\
(-2) \\
\end{array}$ & & \\
\hline $\mathrm{Al}_{13} \mathrm{~A}_{4} \mathrm{H}_{-32}$ & $\begin{array}{l}50.8 \\
(+3) \\
\end{array}$ & & & & & & & & & & \\
\hline $\mathrm{Al}_{13}(\mathrm{OH})_{32}$ & & & & & $\begin{array}{l}22.0 \\
(+7)\end{array}$ & & & & & & \\
\hline $\mathrm{Al}(\mathrm{OH})_{4}$ & & & & & $\begin{array}{l}1.22 \\
(-1) \\
\end{array}$ & $\begin{array}{l}61.2 \\
(-1) \\
\end{array}$ & & & & & \\
\hline
\end{tabular}

5. táblázat: Alumínium formák megoszlása különböző szerves sav ligandokkal alkotott komplexek vizes oldatában, pH 7. A zárójelben lévö szám a cellákban a komplexek nettó töltését mutatja. Az „A " pedig a ligandumot jelöli az első oszlopban. Illetve a „, $H_{-x}$ ” az $\mathrm{OH}^{-}$(hidroxil csoportok) számát mutatja. Az értékek mol\%-ban vannak feltüntetve. (Dr. Labádi Imre adatai alapján) 

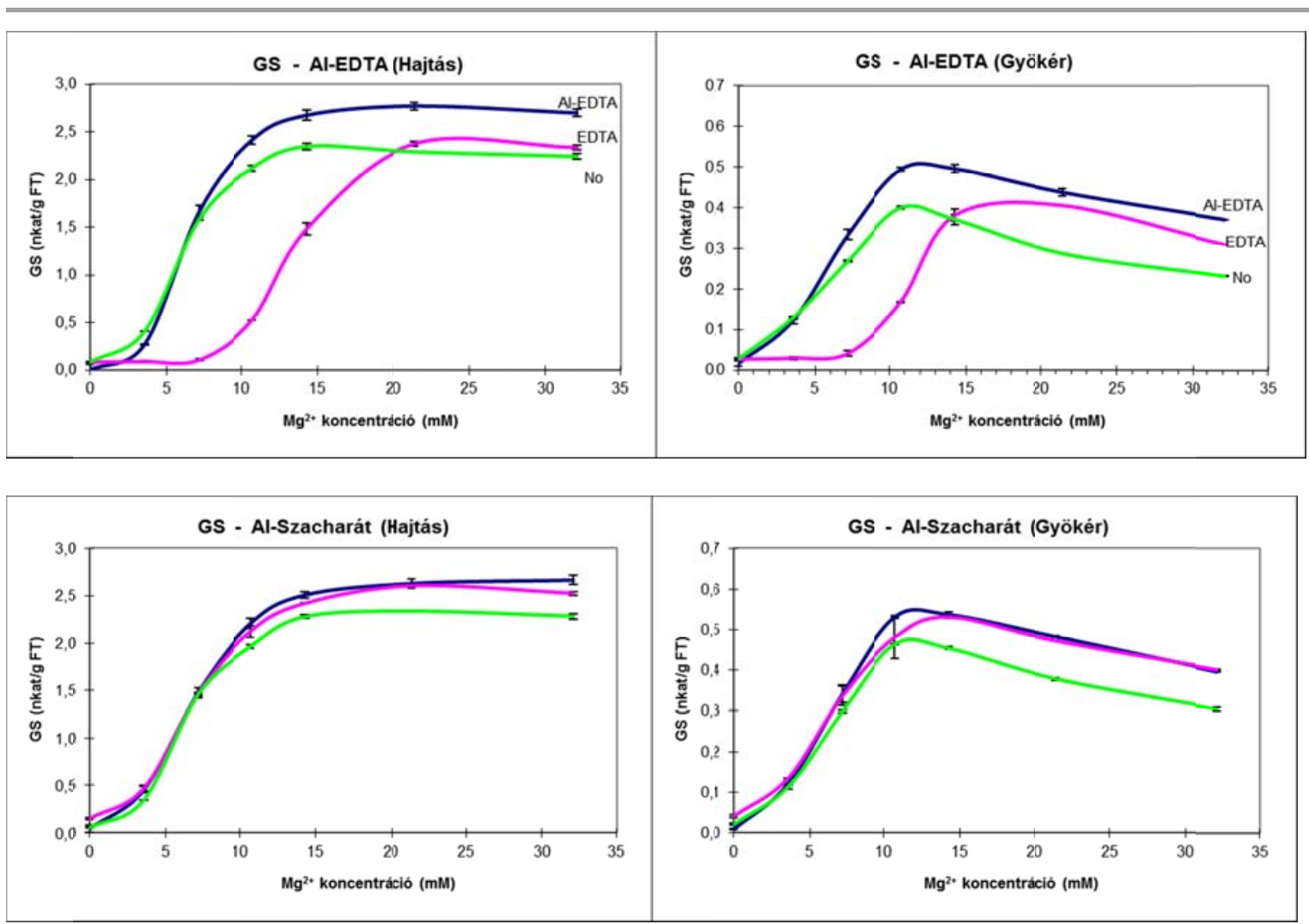

25. ábra: EDTA és szacharát Al-komplexeinek hatása a glutamin szintetáz aktivitására hajtásban és gyökérben. zöld szín: kontroll (desztillált víz) lila: önmagában a szerves savak kék: a szerves sav alumínium komplexe

Korábbi publikált (Kertész és mtsai. 2002) és nem publikált vizsgálatainkban számos szerves sav alumíniummal alkotott komplexének a glutamin szintetázra gyakorolt hatását megnéztük. (25-29. ábra) Ahogy a grafikonokon is látszik több csoportba sorolhatóak a szerves savak a glutamin szintetázra gyakorolt hatásuk alapján. A legszembetűnőbb az, hogy a gyökér és a hajtás eltérően reagál, már a kontroll esetében is. Láthatunk egy optimális magnéziumion koncentrációt, aminél ha több $\mathrm{Mg}^{2+}$ van jelen, akkor már az aktivitás csökken, míg hajtás esetében ilyet nem látunk és egy Michaelis-Menten kinetika szerint alakul a görbe futása növekvő szubsztrát mellett. Ennek oka a GS1 eltérő aktívcentrum szerkezete lehet, és ahogy látjuk a GS1 sok esetben másképp reagál az alumínium komplexekre, mint a hajtásban domináns GS2, például a citromsav esetében. 


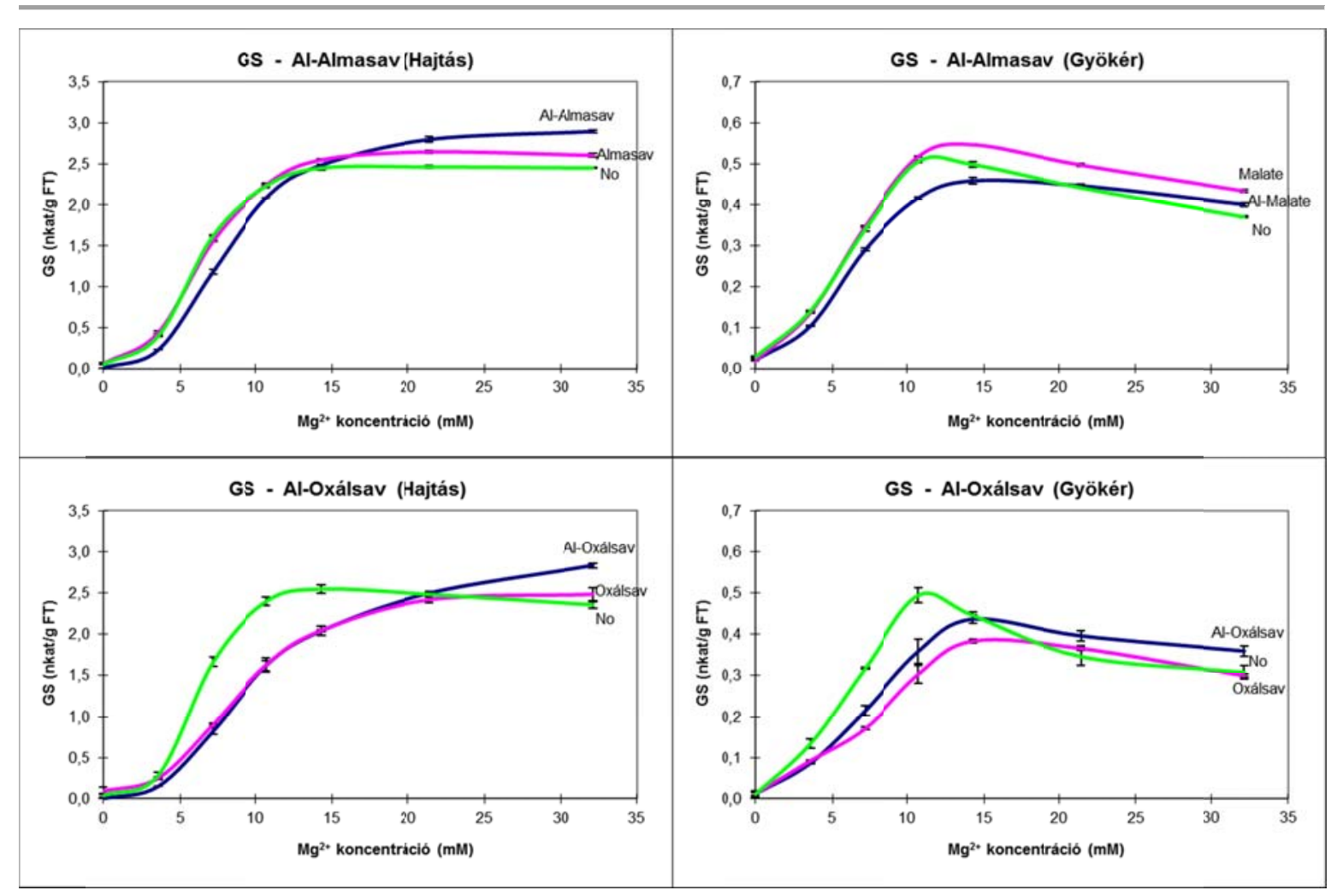

26. ábra: Almasav és oxálsav Al-komplexeinek hatása a glutamin szintetáz aktivitására hajtásban és gyökérben. zöld szín: kontroll (desztillált viz) lila: önmagában a szerves savak kék: a szerves sav aluminium komplexe

A 25. ábrán az EDTA és a szacharát szerves savak által képzett komplexek hatását figyelhetjük meg. Ebben az esetben az enzim aktivitás növekedés kismértékü, és az is csak a gyökér esetében figyelhető meg. Az EDTA magában történő alkalmazásánál a magnéziumot is kelátolja ezért látható a görbe $\mathrm{x}$ tengelyen történő elmozdulása. Ezt a jelenséget figyelhetjük meg az NTA, oxálsav és citromsav esetében is.

A 26. ábrán az oxálsav és almasav hatását látjuk. Itt különösebb enzimaktivitásbeli eltérést nem tapasztalunk. Csak az oxálsavnál tapasztaltunk egy kismértékű eltolódást az x tengely mentén, de a végső aktivitási értékek szinte teljesen azonosak hajtás és gyökér esetén is. 


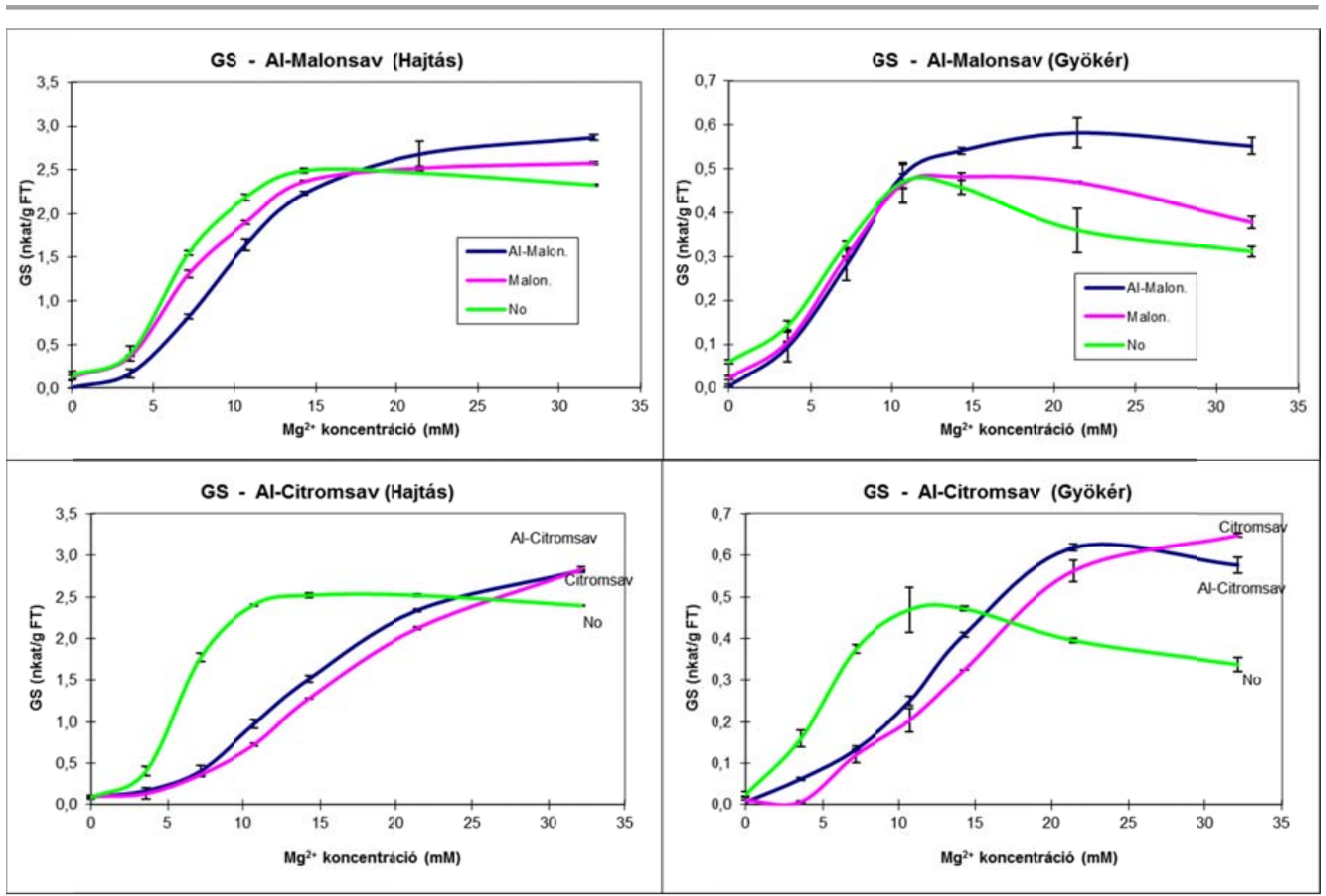

27. ábra: Malonsav és citromsav Al-komplexeinek hatása a glutamin szintetáz aktivitására hajtásban és gyökérben. IV. zöld szin: kontroll (desztillált víz) lila: önmagában a szerves savak kék: a szerves sav aluminium komplexe.

Az citromsavat és malonsavat semlegesnek találtuk az enzim kinetikai mérései során. Ezeknek a savaknak az alumíniummal alkotott komplexeivel felvett enzimaktivitási görbék nem, vagy csak minimális mértékben tértek el a kontroll minta görbéjétől a hajtásban. Meglepő módon azonban a gyökérben nagymértékü növekedést láttunk. Bár a görbék karakterisztikája nagyon eltérő (27. ábra).

A 28. ábrán azokat a komplex képző szerves savak kinetikai görbéit gyüjtöttem össze, amik a legnagyobb mértékben növelték a glutamin szintetáz aktivitását hajtásban és gyökérben egyaránt. 


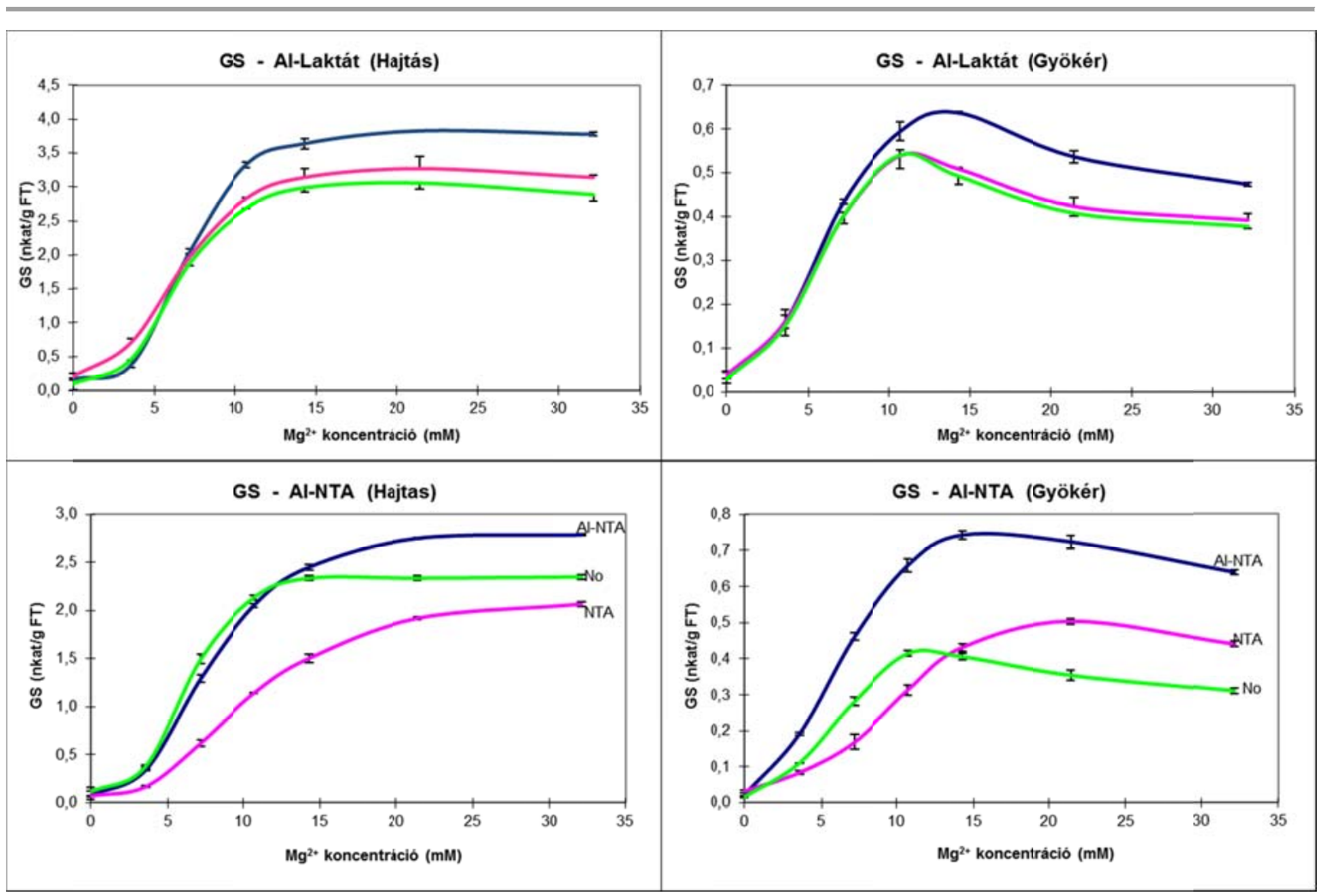

28. ábra: Laktát és NTA Al-komplexeinek hatása a glutamin szintetáz aktivitására hajtásban és gyökérben. I. zöld szín: kontroll (desztillált viz) lila: önmagában a szerves savak kék: a szerves sav alumínium komplexe.

\subsubsection{Az Al(III)NTA hatása a glutamin szintetázra}

Doktori munkámban részletesen azonban csak az Al(III)NTA vizsgálatára összpontosítottunk. Az első és talán legfontosabb megfigyelés, amit tettünk, hogy a Al(III)NTA komplexével kezelt enzim kivonatok gélelektroforézis eljárása után is tartalmaznak $\mathrm{Al}^{3+}$-t. A glutamin szintetázhoz erősen kötődik az alumínium. Az enzimaktivitás változás pedig azt valószínűsíti, hogy a fehérje aktívcentrumában lévő fém kötőhelyekhez kapcsolódik. Illetve a GS tartalmú gélszeletek ICP-AES analízise azonos fémion tartalmakat mutatott a kontroll és az alumínium kezelés esetében, 28,2 $\pm 3,5$ és 32,3 $\pm 3,1$ nmol. Az alumínium kezelés során a GS megőrzi natív, aktív formáját, ezt a natív gélelektroforézis eredményei mutatják, a GS futási tulajdonságai megegyeznek a kezeletlen, kontroll minták futási tulajdonságaival. 


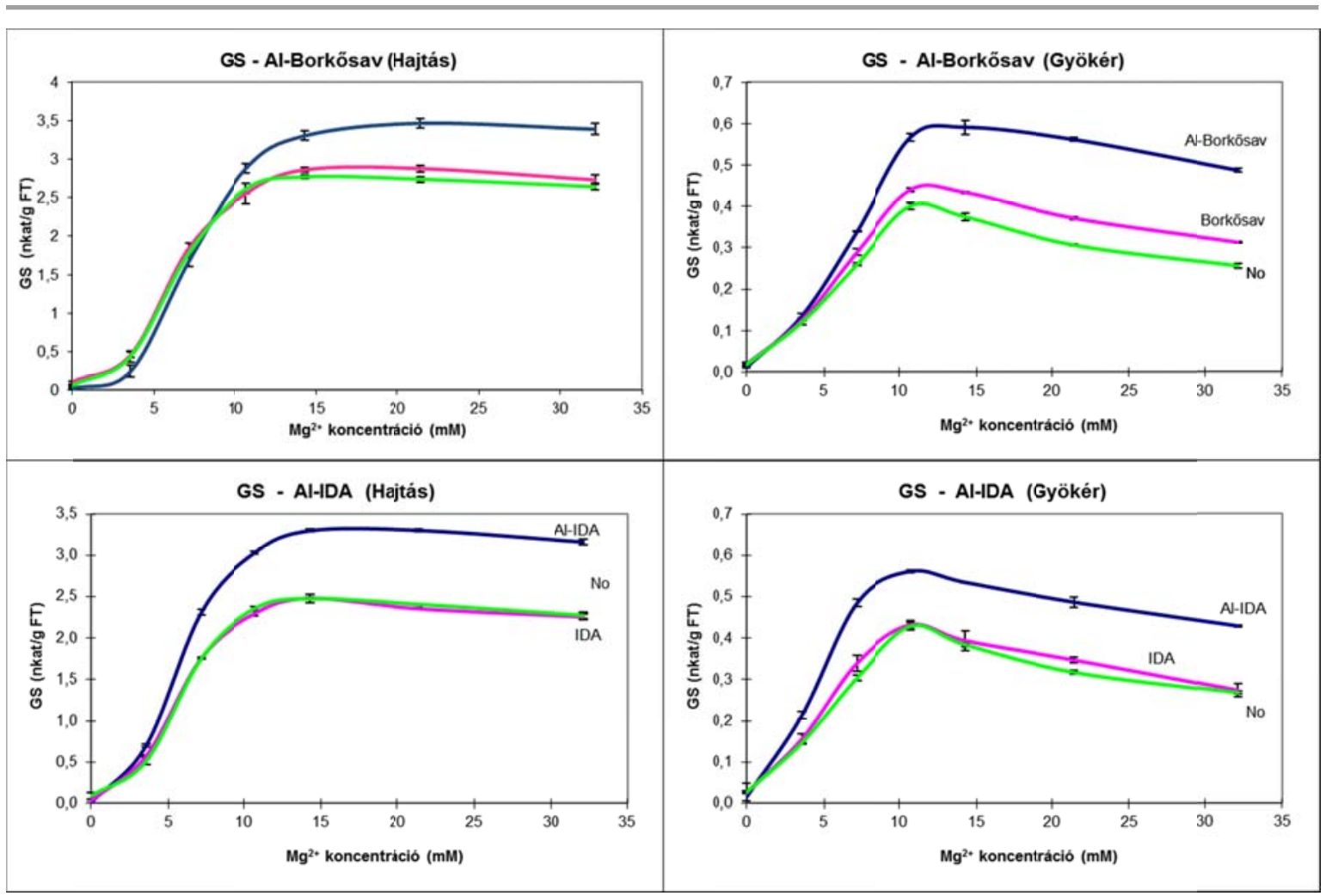

29. ábra: Borkösav és IDA Al-komplexeinek hatása a glutamin szintetáz aktivitására hajtásban és gyökérben. I. zöld szín: kontroll (desztillált viz) lila: önmagában a szerves savak kék: a szerves sav alumínium komplexe.

Az Al(III)NTA növeli a GS aktivitását telítési magnéziumkoncentráció mellett. Azonban az NTA önmagában csökkenti a glutamin szintetáz aktivitását azonos $\mathbf{M g}^{2+}$ koncentrációk mellett, ez annak tudható be, hogy magnéziummal is komplexet képez a nitrilo-triecetav. Az is elmondható, hogy nem igazi kompetítorai az NTA által létrehozott alumínium speciációk a magnézium ionnak, ugyanis a görbe alacsony magnézium koncentráció mellett azonos lefutású, de növekvő $\mathrm{Mg}^{2+}$ szinten pedig látjuk az aktivitás növekedést, pedig ekkor már le kellene szorítnia a magnéziumnak az alumíniumot az enzim aktívcentrumáról. A fehérje fémtartalom vizsgálatai ezt a megfigyelést azzal egészítik ki, hogy a magas alumínium koncentráció mellett növekedett növények leveléből származó enzim is jelentős mennyiségü magnéziumot tartalmazott. Ezek a koncentráció értékek megfelelnek a fiziológiás magnézium tartalmaknak.

Valamint az AI(III)NTA habár növeli a GS aktivitását, mégis önmagában nem tudja működtetni az enzimet, hiszen alacsony magnézium koncentrációnál nem mérünk aktivitást. Tehát elmondható, hogy az enzim működéséhez a magnézium esszenciális, 
nélkülözhetetlen. A glutamin szintetáz plasztidikus izoenzimét tartalmazó gélszeletek fémion tartalom vizsgálatai is ezt támasztják alá. Ugyanis még a magas alumínium koncentráció tartalmú tápoldatban növekedett növények fehérjéjében is találunk magnéziumot. Fontos itt még kiemelni, hogy a kinetikai kísérleteknél pH 7,2-t alkalmaztunk, azaz a sejt fiziológiás körülményei szerint állítottuk be a kémhatást. Ezen a pH-n az Al(III)NTA stabil és oldott formában marad, nem csapódik ki, ugyanúgy mint a növényben található egyéb természetes szerves savak alumínium komplexei (Kochian és mtsai. 2005, Ma és mtsai. 1998). Az 5. táblázat adatai alapján láthatjuk, hogy az Al(III)NTA a következő speciációkban fordul elő: AlA(OH) 89,7 mol\%-ban, az AlA(OH) 2 9,61 mol\%. Az Al(III)IDA esetében ugyan ezen a pH értéken az AlA(OH) 8,7 mol\% és az $\mathrm{AlA}(\mathrm{OH})_{2}$ 91,1 mol\% és nagyobb enzim aktivitási értékeket kaptunk. Az alumínium borkősavval alkotott komplexében az $\mathrm{AlA}(\mathrm{OH})_{2}$ 48,2 mol\% és itt az aktivitási érték az Al(III)NTA és az Al(III)IDA közzé esik (29. ábra). Ezek alapján elmondható, hogy a megnövekedett aktivitásért az $\operatorname{AlA}(\mathrm{OH})_{2}$ forma a felelös, az enzim aktivitás növekedése arányos ennek a formának a százalékos jelenlétével.

$\mathrm{Az}$ in vivo vizsgálatok megmutatják, hogy ténylegesen transzportálódik az alumínium búza növényekben a gyökéren keresztül a hajtásba. Arra vonatkozóan, hogy ilyenkor az alumínium-klorid milyen formában kerül szállításra, nincsenek, csak szakirodalmi adataink (Ma és Furukawa, 2003). De ebben az esetben is enzimaktivitás növekedést mértünk. Az alumínium koncentráció növekedésével párhuzamosan kismértékü magnézium koncentráció csökkenést detektáltunk. Ennek oka a fehérjék eltérő fémion kötő affinitásában keresendő és mérésekkel igazoltuk in vitro, hogy a glutamin szintetáz is köt meg alumíniumot a magnézium rovására. Tehát az in vitro kísérletek az in vivo kapott eredményeket alátámasztják és megerősítik.

A kapott fémtartalom eredmények és az enzimaktivitási értékek alapján tehát azt lehet elmondani, hogy a glutamin szintetázban található két fémion kötőhely eltérő affinitással bír. Az egyik képes kötni az alumíniumot, a másik pedig nem, és az felelős az enzim aktivitás létrejöttéért (esszenciális), míg a másik csak a megnövekedett enzimaktivitásáért.

Konlúzióként elmondható, hogy a különböző stressz türése a növényeknek nagyon összetett folyamatok összesége. Nem lehet csak egy tulajdonság vagy enzim jelenléte vagy hiánya alapján determinálni egy-egy genotípus toleranciáját vagy szenzitivitását egy-egy 
negatív környezeti hatásra. De a glutamin szintetáz képes a növény állapotáról információt adni. Közvetlenül nem felelös a stressz türésért, de hủen ad információt egy adott búza fajta mezőgazdasági szempontból értékelt toleranciájáról vagy érzékenységéről, ugyanis a levelek nitrogén anyagcseréjét jól tükrözi a glutamin szintetáz izoenzimek mennyisége és aránya, és a kloroplasztiszok intaktságáról, müködéséről és müködőképességéről is információt ad a Rubiscoval együtt. Az alumíniumstressz esetében is indikátorként viselkedik, de itt már közvetlen a szerepe, hiszen kötni képes az alumínium iont és az aktvitás növekedést okoz. Ezeknek a tényeknek a tükrében későbbi stresszélettani kutatások célpontja lehet ez az enzim és más abiotikus vagy biotikusstressz folyamatokban betöltött szerepe is érdeklődésre tarthat számot. 


\section{7. Összefoglalás}

A mezőgazdasági termelésben nagyon fontos, hogy a növények megfelelő környezetben tudjanak növekedni, fejlődni és termést hozni. Ezt kétféle módon lehet elérni. Az egyik, hogy megfelelő agrotechnikával biztosítják a megfelelő tápanyag és vízellátottságot, a kórokozók és gyomok ellen megfelelő vegyszerekkel védekeznek. A másik, hogy olyan növényeket termesztenek, amik képesek alkalmazkodni az élettanilag nem optimális körülményekhez. Természetesen a legjobb hatásfokot a két mód párhuzamos és megfelelő használata jelenti. A növények kiválasztásánál fontos, hogy a nemesítés során megfelelő élettani tulajdonságokra tudják szelektálni őket. Kutatásaink során a növények stresszre adott válaszait vizsgáltuk a nitrogén metabolizmus egy enzimének aspektusából, hogy ezáltal is jobban megismerjük és megértsük, hogy milyen folyamatok mennek végbe a gabonafélékben. Az itt szerzett adatokat a későbbiekben akár fel tudják használni a nemesítés folyamatában, illetve a további kutatások tükrében jobb modelleket tudjanak felállítani az élőlények túlélési stratégiáiról.

Munkánk során azt a célt tűztük ki magunk elé, hogy két abiotikus stresszhatás, mégpedig a vízhiány és az alumínium jelenléte, hogyan befolyásolja a búza növények (Triticum aestivum L.) nitrogén metabolizmusában kulcsszerepet játszó glutamin szintetáz (GS, EC 6.3.1.2) enzimet.

Az általunk vizsgált búza fajták a következők voltak a szárazságstressz esetében: Cappelle Desprez, Mv Emese, GK Élet, Kharchia, Kobomugi és Plainsman V. Az alumínium hatásait Jubilejnaja-50 nevü búzafajtán vizsgáltuk. A mintavétel időpontjaként a stresszhatás szempontjából legjelentősebb időszakokat választottuk. Ez a szárazságstressz esetében a szemfeltöltődési időszak volt, mivel a terméseredményeket ez a fejlődésiszakasz határozza meg leginkább. A virágzás utáni kilencedik napot választottuk ki a mérések időpontjaként. Az alumíniumstressz esetében pedig a fiatal 1 hetes csíranövényeket vizsgáltuk. Az alumínium hatása már ebben az időszakban is jelentős a gyökér növekedésének gátlása miatt. 


\section{Szárazságstressz}

A növényeket a szárazságstressz hatására már szemmel láthatóan is két külön csoportokra lehetett osztani. Azonban az öntözött körülmények között nem volt eltérés a genotípusok között a levélöregedés szempontjából. A virágzás utáni kilencedik napon mindegyik búzanövény az egyszíkủekre jellemző szekvenciális öregedést mutatta kontroll körülmények között. De vízhiány hatására a Cappelle Desprez, GK Élet és a Kobomugi felgyorsult zászlóslevél elszáradást mutatott, míg a Plainsman V, Mv Emese és Kharchia megtartotta a szekvenciális öregedésre jellemzö levél leszáradási sorrendet.

A fehérje koncentráció változások is két féle mintázatot mutattak. Szárazság hatására a Cappelle Desprez, GK Élet és Kobomugi fajtákban a zászlóslevelekben kisebb fehérjekoncentrációt mértünk, mint az alatta lévő levélben. A többi búza genotípus esetében a zászlóslevélnek volt magasabb fehérje tartalma.

Rubisco mennyiségének változásai követték az összes oldott fehérje koncentrációváltozásokat mindegyik genotípus esetében.

$\mathrm{Az}$ in vitro mért glutamin szintetáz aktivitás az öregedő levelekben drasztikusan lecsökkent. A levelekben mért fehérje koncentráció csökkenéssel együtt csökkent a GS aktivitás is.

Az öregedő levelekben a kloroplasztiszban elhelyezkedő GS2 bomlott le elöször. A citoszólikus GS1 mennyisége nem csökkent, egyes esetekben még növekedést is mutatott.

Eredményeink alapján megállapítható, hogy a GS2 jó indikátora a kloroplasztisz állapotának, illetve a GS aktivitás változása jól korrelál a növény öregedési folyamataival. Vizsgálataink során kimutattuk, hogy az általunk vizsgált búza genotípusok két eltérő szárazságstressz elleni stratégiával rendelkeznek. A Cappelle Desprez, GK Élet és Kobomugi a „menekülő” stratégiát alkalmazza, míg a Plainsman V, Mv Emese és a Kharchia pedig a „toleráns” stratégiát. Élettani szempontból mindkét stratégia megfelelő, hiszen a növény szaporodása biztosított, de mezőgazdasági szempontból az utóbbi a kedvező. 


\section{Alumíniumstressz}

Az alumínium klorid savas kémhatáson a búzanövény, elsősorban a gyökér növekedését gátolja, de nagy koncentráció esetén már a hajtás növekedése is sérül.

A búza leveléből izolált glutamin szintetázra az általunk vizsgált szerves savak többféleképpen hatnak. Ennek hátterében a pH 7,5-ös kémhatáson megjelenö különböző alumínium formák állnak. A vizsgálataink alapján a GS-re az $\mathrm{AlA}(\mathrm{OH})_{2}$ forma hat aktivitás növelöen. (Az $A$ az adott szerves savat jelöli.)

$\mathrm{Az}$ in vitro az $\mathrm{Al}(\mathrm{III}) \mathrm{NTA}$ a GS aktivitását növeli növekvő magnéziumion koncentráció mellett. Kimutattuk, hogy az aktivitás növekedést az alumínium közvetlen és erős kötődése okozta. A glutamin szintetáz két fémkötőhellye közül az egyik specifikusabb ahhoz csak $\mathrm{Mg}^{2+}$ tud kötődni, de a másik kötőhely affinitása kisebb. A magnéziumion jelenléte mindenképpen szükséges a GS müködéséhez.

In vivo kimutattuk, hogy az egyhetes búzanövények alumíniumot képesek felvenni a tápoldatból és a hajtásba transzportálni, ahol szintén a GS aktivitás növekedését mutattuk ki.

Eredményeink alapján elmondható, hogy a glutamin szintetáz a növényvilágban a szárazság és fémion kötőhellyel rendelkező fehérjeként a fémstresszben is fontos szerepet játszó enzim. Kutatásaink zárószavaként kijelenthetjük, hogy a GS indikátor szerepének fontosságát a későbbi kutatások során vagy gyakorlati alkalmazások fejlesztésekor (pl. egyes növény genotípusok toleranciájának tesztelése, vagy toxikus alumínium jelenlét kimutatása) figyelembe kell venni. 


\section{Summary}

The quantity and quality of crop yield depends on the stress resistance of plants. On the one hand, plants require adequate agrotechniques, optimal supply of nutrients, minerals and water; and protection against weeds and causative agents of diseases for the improved yield. On the other hand, we need plants that are adapted to non-optimal environments. Of course the parallel application of both strategies yields the best result. The analysis of the stress responses is important in the selection of plants. In our study we have investigated the drought and aluminium stress responses in wheat (Triticum aestivum L.) from the aspect of the nitrogen metabolism and glutamine synthetase (GS, EC 6.3.1.2).

Our drought stress experiments were carried out on two Hungarian and four internationally known wheat genotypes: Triticum. aestivum L. cv. MV Emese, a droughtresistant Hungarian cultivar, T. aestivum L. cv. GK Élet, a drought-sensitive Hungarian cultivar, T. aestivum L. cv. Plainsman V, a drought-resistant North American cultivar, the drought-sensitive French T. aestivum L. cv. Cappelle Desprez and two special landrace breeds, Kobomugi and Kharchia. Kobomugi is a facultative spring landrace derived from inner Asia (China, Central Deserts); Kharchia is a tall, Indian landrace wheat cultivar. The breeding pedigree analysis showed a closer genetic relationship between the two Hungarian cultivars: similar ancestors were found, and the difference in drought susceptibility was clearly established. The aluminium treated plants were two-week old seedlings of $T$. aestivum L. cv. Jubilejnaja-50.

Wheat (Triticum aestivum L.) is one of the main crops consumed by humans and it is cultivated in different environments. Under the temperate zone early summer droughts are increasingly frequent and limit grain yield since they coincide with the grain filling period of most cereals, including wheat. The most important parameter of wheat for which genotypes are screened during the process of breeding is the grain yield. But determining grain yield is time-consuming, as wheat plants have to be bred until the maturity of the grains. Therefore the selection would be time and energy saving, if a standard test system were worked out based on the correlations of certain physiological parameters and the drought tolerance and grain yield. 
The main goals of this Ph.D. work were the following:

- How do the sink-source relations change under drought stress in sensitive and tolerant wheat genotypes?

- What are the connections between carbon and nitrogen metabolism under drought stress?

- How does the activity, amount and isoenzyme ratio of under drought stress?

- What is the effect of aluminium in wheat seedlings in acidic environment?

- Does aluminium have a direct influence to the glutamine synthetase?

- What is the effect of $\mathrm{Al}(\mathrm{III}) \mathrm{NTA}$ on glutamine synthetase?

- Does glutamine synthetase have a general role in abiotic stresses?

\section{Drought stress}

Water stress has a considerable impact on the ecosystem and agriculture. Drought during the grain filling period reduces photosynthesis, induces early senescence and shortens the grain filling period. Wheat shows a sequential type of leaf senescence. During the growth of the plant, new leaves are successively formed at the top, and pass successive developmental stages; from maturation up to the last phase of senescence including cell death. In monocarpic plants, developing grains represent the most important sink for carbon and nitrogen and other nutrients after anthesis.

Early studies have showed that glutamine synthetase (GS) is widely distributed in the plant body and occurs in two major forms, one in the chloroplast (GS2) and one in the cytosol (GS1). GS plays a central role in nitrogen metabolism and there are multiple regulatory controls at the gene and protein level to modify its activity. The expression of GS1 is enhanced in later stages of flag leaf development, which may facilitate the recovery of $\mathrm{N}$ during senescence and also signal to the plant that the conditions are right for successful seed filling and maturation. During the vegetative stage, GS2 is the predominant isoenzyme in the leaf mesophyll cells, where it assimilates ammonia originating from nitrate reduction and photorespiration. GS1 is responsible for the generation of glutamine in the remobilization of nitrogen via the phloem. Because of the severe reduction in biomass production during the vegetative stage, there is a shortage of nitrogen and carbon assimilates in senescing source organs, which causes a limitation of remobilization into sink organs. Thus, severe reduction in grain filling could occur in the knockout mutants. Immunolocalisation studies in rice have shown that cytosolic GS has 
multiple metabolic functions such as assimilating ammonia into glutamine for transport and distribution throughout the plant. Anthesis triggers the start of global changes in wheat leaf metabolism characterized by the co-ordinated and gradual decline of RNA, soluble proteins, chlorophyll, Rubisco subunits and GS2. There is a correlation between the amounts of leaf chloroplastic GS and Rubisco protein during senescence, which suggests their co-ordinated regulation during grain development and filling in wheat. Studies on natural and induced senescence in leaves have identified a co-ordinated sequence of biochemical and structural events in chloroplast degradation as well.

Wheat is one of the main crops consumed by humans and it is cultivated in different environments. In this study we observed four tolerant (MV Emese, Plainsman V, Kharchia, Kobomugi) and two sensitive (GK Élet, Cappelle Desprez) genotypes, which are widely used in agriculture. We examined protein, Rubisco and GS amounts and activities in leaves during the grain filling period in search for the traits that ultimately induce sequential senescence and the stay-green stage.

In our work, the total protein content of the leaves, measured at the 9th DPA (days post anthesis), decreased with the age of leaves in all well-watered plants. Under drought stress, the protein content gradient changed in the sensitive cultivars: protein content in the flag leaf was lower than in the older leaf. However, the protein contents measured in leaves of tolerant genotypes followed the same tendency as well-watered plants.

The well-watered and drought stressed individuals of stress resistant breeds (Plainsman V, MV Emese, Kharchia) showed the same senescence pattern, while in the sensitive genotypes (Cappelle Desprez, GK Élet), the protein contents of the flag leaf decreased earlier than in the older leaves during drought stress.

Our results are in agreement with previous experiments. Rubisco starts to be degraded 8-10 days after anthesis and releases amino acids that are further translocated to the seeds. During this period the total GS activity of the flag leaf decreased. It is likely that the decrease in GS2 protein is partly responsible for the decrease in total leaf enzyme activity. The total protein and Rubisco contents of leaves decrease in senescing tissues. The wheat senescence is sequential. In the old leaves the assimilating processes shut down earlier than in the younger leaves. The gradient of the protein content and GS activity is steeper in the tolerant breeds than the sensitive ones. Under water deficit stress we noticed two different modes of senescence. We measured the enzyme activities and protein contents in drought stressed plants in different genotypes. Under drought the order of leaf 
senescence collapsed in sensitive breeds, and the gradient of the decrease of protein content was steeper. The normal order of senescence ceased in these breeds and an irregular senescencing process started. In the tolerant genotypes, drought stress did not lead to a significant deviation in the total protein content and GS enzyme activities. Drought stress simply accelerated the senescence, but the sequentiality was preserved. The extent of this acceleration may refer to the degree of tolerance. In summary, the tolerant breeds were able to adapt to drought circumstances (water potential, photosynthesis, etc.).

The sensitive breeds could not adapt to the drought and their strategy was to escape drought stress with faster crop development, therefore the nutrients were transported from the flag leaf to the seeds. So from the flag leaves the nutrients were saved to the seeds. The normal gradient of senescence collapsed and the youngest leaves were degraded: the flag leaf converted to a catabolic source before the conversion of the older leaves. This untimely senescence of the flag leaf is the indicator of drought stress sensitivity. They could only develop crop under drought.

The Kobomugi genotype originates from a semi-arid region from inner Asia. Parameters of the senescence process were similar to the sensitive genotypes. This breed could not develop much crop, only a few seeds per plant. The whole plant shrivelled, and its lifecycle was very fast. We found a drastic decrease of the GS activity in the flag leaf under drought stress. This is in agreement with previous experiments showing that Kobomugi tends to be a drought stress escaper.

Overall, the total protein content, GS enzyme activities and the presence of GS isoforms together are good indicators of drought stress tolerance of wheat cultivars. The increasing ratio of cytoplasmic and chloroplastic GS, the decomposition of protein content, mainly Rubisco, are the signs of accelerated senescence induced by water deficit. A moderate drought can accelerate grain filling too. This acceleration of senescence is found in drought tolerant wheat cultivars. In drought-sensitive ones, however, the function of the last assimilatory source, the flag leaf, ceases and it is converted to a catabolic source, which supplies the developing grain for a shorter time. With these parameters the distinct survival strategies of different wheat cultivars can be clearly revealed. The physiological differences are well reflected in the different senescence processes. 
Aluminium stress

Acidification of soils may release water soluble, toxic aluminium species from clay minerals. Al interferes with a wide range of physical and cellular processes. Glutamine synthetase (GS, EC 6.3.1.2) is the key enzyme of primary $\mathrm{N}$ assimilation, as well as ammonia reassimilation and detoxification. Plant GS requires two magnesium ions per subunit for activity, which makes GS a potential target of metal stress. The objective of this investigation was to prove that $\mathrm{Al}$ from an organic metal complex is able to activate GS, and Al becomes bound to the polypeptide structure of the GS molecule. Aluminium(III)-nitrilotriacetic acid complex (Al(III)NTA) activated the GS prepared from wheat (Triticum aestivum L.) leaves, as $\mathrm{Al}^{3+}$ did in vivo, but could not functionally substitute magnesium ions, which were also necessary for the activity in the in vitro GS assay. GS2 was isolated by non-denaturing polyacrylamide gel electrophoresis, and the $\mathrm{Al}$ and $\mathrm{Mg}$ content of the enzyme was determined by inductively coupled plasma atomic emission spectroscopy. The GS octamer remained intact and contained $\mathrm{Mg}^{2+}$ bound to its specific sites after the electrophoretic separation. Al was detected in the Al(III)NTAtreated sample bound to the structure of the enzyme protein, potentially occupying one of the specific metal-binding sites of the subunits. Our results indicate that the activator effect of the Al(III)NTA complex is because of specific binding of aluminium to the polypeptide chain of GS2; however, the presence of magnesium at least on one of the metal-binding sites is essential to the active state of the enzyme.

The positive effect of organic $\mathrm{Al}(\mathrm{III})$ complexes on the glutamine synthetase activity depends on the speciation of the $\mathrm{Al}(\mathrm{III})$ complexes. Our study concludes, that the $\mathrm{AlA}(\mathrm{OH})_{2}$ form of $\mathrm{Al}(\mathrm{III})$ complexes is the most effective species in GS assays.

In summary, our results indicate that $\mathrm{Al}^{3+}$ taken up by roots from the acidic nutrient solution can reach the leaf cells and there it can increase the glutamine synthetase activity in vivo. In our model experiment Al(III)NTA complex activated the isolated GS in vitro. In both cases, the activation is because of specific binding of aluminium to the polypeptide chain of GS2, however presence of magnesium at least on one of the metal-binding sites is essential to the active state of the enzyme. 


\section{Köszönetnyilvánítás}

Köszönöm témavezetőmnek Dr. Pécsváradi Attila egyetemi docensnek az éveken át tartó szakmai irányítását, értékes tanácsait mind elméleti, mind gyakorlati téren. Köszönöm a bátorításait, amivel átlendített a bizonytalan, sikertelennek látszó időszakokon.

Köszönet Prof. Dr. Erdei László egyetemi tanárnak és Dr. Görgényiné Dr. Tari Irma egyetemi docensnek, a Növényélettani, majd később Növénybiológiai Tanszék vezetőinek, akik hozzá járultak, hogy a tanszéken készíthessem el diplomamunkámat és doktori disszertációmat, a pályázatokban és konferenciákon való részvétel segítését.

Szeretném megköszönni a szegedi Gabonatermesztési Kutatóintézetből Dr. Cseuz Lászlónak a kísérletekhez biztosított vetőmagokat, szakmai tanácsokat.

Köszönöm Németh Edit PhD hallgató segítségét, türelmét az elvégzett munkákban, az együtt töltött idő alatt a töretlen jókedvét. Köszönöm Molnár Réka szakdolgozó segítségét az alumíniummal kezelt növények vizsgálatánál.

Köszönet Dr. Vashegyi Ágnesnek, a növényneveléshez nyújtott segítségéért, valamint Dr. Julie Cullimore-nak a toulouse-i egyetemről, aki önzetlenül GS antitestet bocsátott a rendelkezésünkre.

Köszönettel tartozom a Növénybiológiai Tanszéken dolgozó munkatársaknak, PhD hallgatóknak, laboránsoknak a jó hangulatért és a munkám során nyújtott segítségért, lelki támogatásért!

Köszönöm az MTA Agrártudományi Kutatóintézet Kukoricanemesítési Osztály vezetésének, munkatársainak, hogy doktorimunkám befejezését lehetővé tették, támogatták.

Köszönöm családom minden tagjának a támogatását és szeretetét, amivel minden helyzetben kiálltak mellettem és az egyetemi és a doktori időszak alatt is bátorítottak, ösztönöztek és nem csak anyagilag finanszírozták tanulmányaimat.

Soli Deo Gloria 


\section{Publikációs lista}

(*az értekezéshez közvetlenül kapcsolódó közlemények)

\section{Cikkek:}

* Pécsváradi, A., Nagy, Z., Varga, A., Vashegyi, Á., Labádi, I., Galbács, G. and Zsoldos, F. Chloroplastic glutamine synthetase is activated by direct binding of aluminium. DOI: 10.1111/j.1399-3054.2008.01167.x Physiologia Plantarum 135: 43-50, 2009. (IF: 2,708)

Nagy, Z., Németh, E., Gallé, Á., Csiszár, J., Erdei, L. and Pécsváradi, A. Changes in nitrogen metabolism of different wheat cultivars following Fusarium infection. HURO/0901/1472.2.2 Szeged - Timişoara axis for the safe food and feed SZETISA1, Book of Final Report, pp. 61-67, Szeged, 2012.

* Nagy, Z., Németh E., Guóth, A., Bona, L., Wodala, B., Pécsváradi, A. Metabolilc indicators of drought stress tolerance in wheat: Glutamine synthetase isoenzymes and Rubisco. DOI: 10.1016/j.plaphy.2013.03.001 Plant Physiology and Biochemistry 67, 48-54, 2013. (IF: 2,838)

\section{Poszterek:}

Nagy, Z. and Pécsváradi, A.: Wheat Chloroplastic Glutamine Synthetase Is Activated by Aluminium, 3rd IFSDAA International Seminar on Crop Science for Food security, Bio-energy and Sustainability 1-3 June 2010 in Szeged, Hungary

Nagy, Z., Aleksza, D., Pécsváradi, A.: Aluminium activates the chloroplastic glutamine synthetase in wheat, 11th International Symposium Interdisciplinary Regional Research, 13-15. October 2010, Szeged, Hungary 
Nagy, Z., Péter Szabó, K., Németh, E., Pécsváradi, A.: Glutamine synthetase isoenzymes of Nicotiana tabacum callus of leaf origin, A Magyar Növénybiológiai Társaság X. Kongresszusa, 2011. augusztus 31. - szeptember 2., Szeged, Magyarország

Nagy, Z. and Pécsváradi, A.: Role of glutamine synthetase isoenzymes and Rubisco in drought stress, 5th Conference of the Polish Society of Experimental Plant Biology, September 6, 2011 - September 9, 2011, Wroclaw, Poland

\section{Előadás, prezentáció:}

Pécsváradi, A., Nagy, Z., Németh, E.: Changes in glutamine synthetase activity and in protein pattern of wheat leaves after Fusarium infection. Szeged - Timisoara axis for the safe food and feed (SZETISA1), Hungary - Romania Cross-Border Co-operation Programme 2007-2013, Timisoara, Romania, January 26-27.01.2012

Nagy, Z., Németh, E., Pécsváradi, A.: Separation of protein content of stressed poplar leaves by two-dimensional polyacrylamide gel electrophoresis. Characterization and oxidative stress tolerance in plants: from models to trees (OXIT), Hungary-Serbia IPA Cross-border Co-operation Programme, November 20, 2012, Szeged, Hungary

A Magyar Tudományos Művek Tára adatbázisában szereplő közleményjegyzék: https://vm.mtmt.hu//search/slist.php?lang=0\&AuthorID=10027485

A Ph. D. értekezés alapjául szolgáló munkát a "Búzakalász” konzorciumi pályázat (NKFP 4/064/2004), a T46692 számú OTKA pályázat, valamint a TÁMOP-4.2.2/B-10/1-20100012 pályázat tette lehetővé. 


\section{Felhasznált irodalom}

Ali, M., Jensen, C.R., Mogensen, V.O., Andersen, M.N., Henson, I.E., (1999) Root signalling and osmotic adjustment during intermittent soil drying sustain grain yield of field grown wheat. Field Crops Research, 62, 35-52.

Ananieva, K., Ananiev, E.D., Doncheva, S., Georgieva, K., Tzetkova, N., KamíneK, M., Motyka, V., Dobrev, P., Gajdošová, S., Malbeck, J. (2008) Senescence progression in a single darkened cotyledon depends on the light status of the other cotyledon in Cucurbita pepo (zucchini) seedlings: potential involvment of cytokinins and cytokinin oxidase/dehydrogenase activity. Physiologia Plantarum, $134,609-623$.

Arroyo-Serralta, G.A., Kú-GonZalez, Á., HernÁndez-Sotomayor, S.M.T., Aguilar, J.J.Z. (2005) Exposure to toxic concentrations of aluminum activates a MAPK-like protein in cell suspension cultures of Coffea arabica. Plant Physiology and Biochemistry, 43, 27-35.

Azcón, R., ToBAR, R.M. (1998) Activity of nitrate reductase and glutamine synthetase in shoot and root of mycorrhizal Allium cepa. Effect of drought stress. Plant Sciences, $133,1-8$.

Bahrman, N., Gouy, A., Devienne-Barret, F., Hirel, B., Vedele, F., Le Gouis, J. (2005) Differential change in root protein patterns of two wheat varieties under high and low nitrogen nutrition levels.Plant Science, 168, 81-87.

Barbottin, A., Lecomte, C., Bouchard, C., Jeuffroy, M.-H. (2005) Nitrogen remobiliztation during grain filling in wheat: genotypic and environmental effects. Crop Science, 45, 1141-1150.

BARlett, R.J., RIEGO, D.C. (1972) Effect of chelation on the toxicity of aluminum. Plant and Soil, 37, 419-423.

BARnABÁs , B., JÄGER K., FEHÉR, A. (2008) The effect of drought and heat stress on reproductive processes in cereals. Plant, Cell and Environment, 31, 11-38.

BARNEIX, A.J. (2007) Physiology and biochemistry of source-regulated protein accumulation in the wheat grain. Journal of Plant Physiology, 164, 581-590.

Basu, U., GodBold, D., TAYlor, G. (1994) Aluminium resistance in Triticum aestivum associated with enhanced exudation of malate. Journal of Plant Physiology, 144, $747-753$ 
BÄsinger, M., Edmeades, G.O., Lafitte, H.R. (2002) Physiological mechanisms contributing to the increased $\mathrm{N}$ stress tolerance of tropical maize selected for drought tolerance. Field Crops Research, 75, 223-233.

Bennett, M.J., Cullimore, J.V. (1989) Glutamine synthetase isoenzymes of Phaseolus vulgaris L.: subunit composition in developing root nodules and plumules. Planta, $179,433-440$.

Bernhard W.R., MAtiLe P. (1994) Differential expression of glutamine synthetase genes during senescence of Arabidopsis rosette leaves. Plant Science, 98, 7-14

Bertamini, M., Nedunchezhian, N. (2002) Leaf age effects on chlorophyll, Rubisco, photosynthetic electron transport activities and thylakoid membrane protein in field grown grapevine leaves. Journal of Plant Physiology, 159, 799-803.

Bradford, M.M. (1976) A Rapid and Sensitive Method for the Quantitation of Microgram Quantities of Protein Utilizing the Principle of Protein-Dye Binding. Analytical Biochemistry, 248-254.

Buchanan-Wollaston, V., Earl, S., Harrison, E., Mathas, E., Navabpour, S., Page, T., PINK, D. (2003) The molecular analysis of leaf senescence - a genomics approach. Plant Biotechnology Journal, 1, 3-22.

CANvin, D.T. (1990) Photorespiration and $\mathrm{CO}_{2}$-concentrating mechanisms. In: Dennis, D.T. \& Turpin, D.H. Eds. Plant Physiology, Biochemistry and Molecular Biology. London, Longman Scientific \& Technical, pp. 253-273.

Cattivelli, L., Rizza, F., Badeck, F.-W., Mazzucotelli, E., Mastrangelo, A.M., Francia, E., Marè, C., Tondelli, A., StancA, A.M. (2008) Drought tolerance improvement in crop plants: An integrated view from breeding to genomics. Field Crops Research, 105, 1-14.

ChandleE, J.M. (2001) Current molecular understanding of the genetically programmed process of leaf senescence. Physiologia Plantarum, 113, 1-8.

Chang, Y. C., Ma, J. F., Matsumoto, H. (1998) Mechanisms of Al-induced iron chlorosis in wheat (Triticum aestivum). Al-inhibited biosynthesis and secretion of phytosiderophore. Physiologia Plantarum, 102, 9-15.

Chen, J., Kennedy, R.J. (1985) Purification and properties of lupin nodule glutamine synthetase. Phytochemistry, 12, 2167-2172.

Chen, F.-L., Cullimore, J.V. (1989) Location of two isoenzymes of NADH-dependent glutamate synthase in root nodules of Phaseolus vulgaris L. Planta, 179, 441-447. 
Chiba, A., Ishida, H., Nishizawa, N.K., Makino, A., Mae, T. (2003) Exclusion of Ribulose-1,5-bisphosphate Carboxilase/oxygenase from Chloroplasts by Specific Bodies in Naturally Senescing Leaves of Wheat. Plant Cell Physiology, 44, 914921.

Csiszár, J., Gallé, Á., Horváth, E., Dancsó, P., Gombos, M., VÁry, Zs., Erdei, L., Györgyey, J., TARI, I. (2012) Different peroxidase activities and expression of abiotic stress-related peroxidases in apical root segments of wheat genotypes with different drought stress tolerance under osmotic stress. Plant Physiology and Biochemistry, 52, 119-129.

Debouba, M., Gouia, H., Suzuki, A., Ghorbel, M.H. (2006) NaCl stress effects on enzymes involved in nitrogen assimilation pathway in tomato „Lycopersicon esculentum" seedlings. Journal of Plant Physiology, 163, 1247-1258.

Delhaize, E., Ryan, P.R. (1995) Aluminium toxicity and tolerance in plants. Plant Physiology, 107, 315-321.

Diaz, C., Lemaître, T., Christ, A., Azzopardi, M., Kato, Y., Sato, F., Morot-Gaudry, J.-F., Le Dily, F., MasclauX-Daubresse, C. (2008) Nitrogen recycling and remobilization are differentially controlled by leaf senescence and development stage in Arabidopsis under low nitrogen nutrition. Plant Physiology, 147, 14371449.

Eisenberg, D., Gill, H.S., Pfluegl, G.M. U., Rotstein S.H. (2000) Structure-function relationships of glutamine synthetase. Biochimica et Biophysica Acta, 1477, 122-145.

Erdei, L., Trivedi, S., Takeda, K., Matsumoto, H. (1990) Effects of osmotic and salt stresses on the accumulation of polyamines in leaf segments from wheat varieties differing in salt and drought tolerance. Journal of Plant Physiology, 137, 165-168.

Erdei, L., Tari, I., Csiszár, J., Pécsváradi, A., Horváth, F., Szabó, M., ÖrdöG, M., Cseuz, L., Zhiponova, M., Szilék, L., Györgyey, J. (2002) Osmotic stress responses of wheat species and cultivars differing in drought tolerance: some interesting genes (advice for gene hunting). Acta Biologica Szegediensis, 46, 63-65.

Evans, J.R. (1989) Photosynthesis and nitrogen relationships in leaves of $\mathrm{C}_{3}$ plants. Oecologia, 78, 9-19.

Fangmeier, A., Chrost, B., Högy, P., Krupinska, K. (2000) $\mathrm{CO}_{2}$ enrichment enhances flag leaf senescence in barley due to greater grain nitrogen sink capacity. Environmental and Experimental Botany, 44, 151-164.

Fei , H., Chaillou, S., Hirel, B., Polowick, P., Mahon, J.D., Vessey, J.K. (2006) Effects of the overexpression of a soybean cytosolic glutamine synthetase gene (GS15) linked to organ specific promoters on growth and nitrogen accumulation of pea plants supplied with ammonium. Plant Physiology and Biochemistry, 44, 543-550. 
Finnemann, J., Schjoerring, J.K. (2000) Post-translational regulation of cytosolical glutamine synthetase by reversible phosphorylation and 14-3-3 protein interaction. The Plant Journal, 24, 171-181.

Foulkes, M.J., Sylvester-Bradley, R., Weightman, R., Snape, J.W. (2007) Identifying physiological traits associated with improwed drought resistance in winter wheat. Field Crops Research, 103, 11-24.

FoYer, C.H., PARRY, M., NOCTOR, G. (2003) Markers and signals associated with nitrogen assimilation in higher plants. Journal of Experimental Botany, 54, 585-593.

Gallé, Á., CsiszÁr, J., Secenji, M., Guóth, A., Cseuz, L., TAri, I., Györgyey, J., Erdei, L. (2009) Glutathione transferase activity and expression patterns during grain filling in fleg leaves of wheat genotypes differing in drought tolerance: Response to water deficit. Journal of Plant Physiology, 166, 1878-1891.

Gallé, Á., Csiszár, J., TARI, I., ERdei, L. (2002) Changes in water and cholorophyll fluoresence parameters under osmotic stressin wheat cultivars. Acta Biologica Szegediensis, 46, 85-86.

Ghosh, S., Mahoney, S.R., Penterman, J.N., Peirson, D., Dumbroff, E.B. (2001) Ultrastructural and biochemical changes in chloroplasts during Brassica napus senescence. Plant Physiology and Biochemistry, 39, 777-784.

Goggin, D.E., SetTer, T.L. (2004) Fructosyltransferase activity and fructan accumulation during development in wheat exposed to terminal drought. Functional Plant Biology, 31, 11-21.

Gubiš, J., VAŇKová, R., ČervenÁ, V., Draguňová, M., HudCovicová, M., LichtNerovÁ, H., DoKuPIL, T., JuREKOVÁ, Z. (2007) Transformed tobacco plants with increased tolerance to drought. South African Journal of Botany, 73, 505-511.

Guóth, A., Tari, I., Gallé, Á., Csiszár, J., Pécsváradi, A., Cseuz, L., Erdei, L. (2009) Comparison of the drought stress responses of tolerant and sensitive wheat cultivars during grain fillings: Changes in flag leaf photosynthetic activity, ABA levels, and grain yield. Journal of Plant Growht Regulation, 28, 167-176.

Guóth, A., Benyó, D., Csiszár, J., Gallé, Á., HorvÁth, F., Cseuz, L., Erdei, L., TARi, I. (2010) Relationship between osmotic stress-induced abscisic acid accumulation, biomass production and plant growth in drought-tolerant and-sensitive wheat cultivars. Acta Physiologiae Plantarum, 32, 719-727.

Herrera-Rodríguez, M.B., Maldonado, J.M., Pérez-Vicente, R. (2005) Role of asparagine and aspragine synthetase genes in sunflower (Helianthus annuus) germination and natural senescence. Journal of Plant Physiology, 163, 1061-1070. 
Hirel, B., Gadal, P. (1980) Glutamine synthetase in rice. A comparative study of enzymes from roots and leaves. Plant Physiology, 66, 619-623.

Kertész, S., FÁBiÁn A., Zsoldos, F., VAshegyi, Á., LABÁdi, I., Bona, L.,PÉCsvÁRAdi, A. (2002) Changes in glutamine synthetase activity in presence of aluminium complexes. Acta Biologica Szegediensis, 46, 103-104.

Kichey, T., Heumez, E., Pocholle, D., Pageau, K., Vanacker, H., Dubois, F., Gouis, J., HiREL, B. (2006) Combined agronomic and physiological aspects of nitrogen managment in wheat highlight a central role for glutamine synthetase. New Phytologist, 169, 265-278.

KInRAIDE, T.B. (1990) Assessing the rhizotoxicity of the aluminate ion, $\mathrm{Al}(\mathrm{OH})_{4}{ }^{-}$. Plant Physiology, 94, 1620-1625.

KinRAIDE, T.B., PARKER, D.R. (1987) Cation amelioration of aluminium toxicity in wheat. Plant Physiology, 83, 546-551.

KInRAide, T.B., PARKeR, D.R. (1990) Apparent phytotoxicity of mononuclear hydroxyaluminium to four dicotiledonous species. Physiologia. Plantarum, 79, 283-288.

KISS, S.A. (1989) Antagonism of magnesium and aluminium in bean and wheat. Acta Agronomica Hungarica, 38, 219-229.

Kochian, L.V., Pineros, M.A., Hoekenga, O.A. (2005) The phisiology, genetics and molecular biology of plant aluminum resistance and toxicity. Plant and Soil, 274, 175-195.

Kumar, R., Sarawgi, A.K., Ramos, C., Amarante, S.T., Ismail, A.M., Wade, L.J. (2006) Partitioning of dry matter during drought stress in rainfed lowland rice. Field Crops Research, 96, 455-465.

LAEMMLI, U.K. (1970) Cleavage of structural proteins during the assembly of the head of bacteriophage T4. Nature, 680-685.

Lam, H.-M., Coschigano, K.T., Oliveira, I.C., Melo-Oliveira, R., Coruzzi, G.M. (1996) The molecular genetics of nitrogen assimilation into amino acids in higher plants. Annual Review Plant Physiology Plant Molecular Biology, 47, 569-593.

LAWLOR, D.W. (2002) Carbon and nitrogen assimilation in relation to yield: mechanisms are the key to understanding production systems. Journal of Experimental Botany, $53,773-787$.

LAYZELL, D.B. (1990) $\mathrm{N}_{2}$ fixation, $\mathrm{NO}_{3}{ }^{-}$reduction and $\mathrm{NH}_{4}{ }^{+}$assimilation. In: Dennis, D.T., Turpin, D.H. Eds. Plant physiology, biochemistry and molecular biology. Longman House, Harlow, England. pp. 399-406. 
LEA, P.J. (1985) Ammonia assimilation and amino acid biosynthesis. In: Coombs, J., Hall, D.O., Long, S.P., Scurlock, J.M.O. Eds. Techniques in bioproductivity and photosynthesis. Pergamon Press, Oxford, England. pp. 173-179.

LeVITT, J. (1972) Responses of plants to environmental stress. Academic Press, N.Y.

MA, J.F., FurukAwA, J. (2003) Recent progress in the research of external A1 detoxification in higher plants: a mini review. Journal of Inorganic Biochemistry, 97, 46-51.

Ma, J.F., Hiradate, S., Matsumoto, H. (1998) High aluminium resistance in buckwheat: II. Oxalic acid detoxifies aluminium internally. Plant Physiology, 117, 753-759.

MAKINO, A., OsMOND, B. (1991) Effects of nitrogen nutrition on nitrogen partitioning betweenchloroplasts and mitochondria in pea and wheat. Plant Physiology, 96, 355-362.

MARCELIS, L.F.M. (1996) Sink strenght as a determinat of dry matter partitioning int he whole plant. Journal of Experimental Botany, 47, 1281-1291.

Masclaux, C., Valadier, M.-H., Brugière, N., Morot-Gaudry, J.-F., Hirel, B. (2000) Characterization of the sink/source transition in tobacco (Nicotiana tabacum L.) shoots in relation to nitrogen managment and leaf senescence. Planta, 211, 510-518.

Matsumoto, H. (2000) Cell biology of aluminum toxicity and tolerance in higher plants. International Review of Cytology, 200, 1-46

MCNally, S.F., Hirel, B. (1983) Glutamine synthetase isoforms in higher plants. Physiologie Vegetale, 21, 761-774

Meyre, D., Leonardi, A., Brisson, G., Vartanian, N. (2001) Drought-adaptive mechanisms involved int he escape/tolerance strategiest of Arabidopsis Landsberg erecta and Columbiana ecotypes and their F1 reciprocal progeny. Journal of Plant Physiology, 158, 1145-1152.

MiYasaKa, S.C, Buta, J.G., Howell, R.K., FoY, C.D. (1991) Mechanism of aluminum tolerance in snapbeans. Plant Physiology, 96, 737-743.

Miflin, B.J., HABASH, D.Z. (2002) The role of glutamine synthetase and glutamate dehydrogenase in nitrogen assimilation and possibilities for improvement in the nitrogen utilization of crops. Journal of Experimental Botany, 53, 979-987.

Nagy, Z., Németh, E., Guóth, A., Bona L., Wodala, B., Pécsváradi, A. (2013) Metabolic indicators of drought stress tolerance in wheat: Glutamine synthetase isoenzymes and Rubisco. Plant Physiology and Biochemistry 67, 48-54. 
Neuhoff, V., Stamm, R., EIBL, H. (1985) Clear background and highly sensitive protein staining with Coomassie Blue dyes in polyacrylamide gels: A systemic analysis. Electrophoresis 6, 427-448.

Nevo, E., Korol, A.B., Beiles, A., Fahima, T. (2002) Evolution of Wild Emmer and Wheat Improvement: Population Genetics, Genetic Resources, and Genome Organization of Wheat's Progenitor, Triticum dicoccoides. Springer.

Noodén, L.D., Guiamét, J.J., John, I. (1997) Senescence mechanisms. Physiologia Plantarum, 101, 746-753.

Parker, D. R., KinRaide, T. B., Zelazny, L. W. (1988) Aluminium speciation and phytotoxicity in dilute hydroxy-aluminium solutions. Soil Science Sociaty of America Journal, 52, 438-444.

Parker, D. R., Kinraide, T. B., Zelazny, L. W. (1989) On the phytotoxicity of polinuclear hydroxy-aluminium complexes. Soil Science Sociaty of America Journal, 53:789-796.

Pécsváradi, A., Nagy, Z., Varga, A., Vashegyi, Á., LabÁdi, I., Galbács, G. AND Zsoldos, F. (2009) Chloroplastic glutamine synthetase is activated by direct binding of aluminium. Physiologia Plantarum 135: 43-50.

Pellet, D.M., PaPernik, L.A., Jones, D.L., Darrah, P.R., Grunes, D.L., Kochian, L.V. (1997) Involvement of multiple aluminium exclusion mechanism in aluminiuim tolerance in wheat. Plant and Soil, 192, 63-68.

Pic, E., DE LA Serve, B.T., TARdieu, F., Turc, O. (2002) Leaf senescence induced by mild water deficit follows the same sequence of macroscopic, biochemical and molecular events as monocarpic senescence in pea. Plant Physioogy,. 128, 236-246.

Portis JR. A.R., PARRY, M.A.J. (2007) Discoveries in Rubisco (Ribulose 1,5-bisphosphate carboxylase/oxygenase): a historical perspective. Photosynthesis Research, 94, 121-143.

Puijalon, S., Bouma, T.J., Douady, C.J., van Groenendael, J., Anten, N.P.R., Martel, E., BornetTe, G. (2011) Plant resistance to mechanical stress: evidence of an aviodance-tolerance trade-off. New Phytologist, 191, 1141-1149.

QuARTACCI M.F., BAKER A.J.M., NAVARI-Izzo F. (2005) Nitrilotriacetate and citric acidassisted phytoextraction of cadmium by Indian mustard (Brassica juncea (L) Czernj, Brassicaceae). Chemosphere, 59, 1249-1255.

QuARTACCI M.F., IRTElli B., BAKER A.J.M., NAVARI-IzZO F. (2007) The use of NTA and EDDS for enhanced phytoextraction of metals from a multiply contaminated soil by Brassica carinata. Chemosphere, 68, 1920-1928. 
Rhodes, D., Rendon, G.A., Stewart, G.R. (1975) The control of glutamine synthetase level in Lemna minor L. Planta, 125, 201-211.

Royo, C., Aparicio, N., Blanco, R., Villegas, D. (2004) Leaf and green area development of durum wheat genotypes grown under Mediterranean conditions. European Journal of Agronomy, 20, 419-430.

Scarpeci, T.E., Marro, M.L., Bortolotti, S., Boggio, S.B., Valle, E.M. (2007) Plant nutritional status modulates glutamine synthetase levels in ripe tomatoes (Solanum Lycopersicum cv. Micro-Tom). Journal of Plant Physioölogy, 164, 137-145.

SeČenji, M., Lendvai, Á., Miskolczi, P., Kocsy, G., Gallé, Á., Szücs, A., Hoffmann, B., SÁrvári, É., Schweizer, P., Stein, N., Dudits, D., Györgyey, J. (2010) Differences in root functions during long-term drought adaption: comparison of active gene sets of two wheat genotypes. Plant Biology, 12, 871-882.

Silveira, J.A.G., Melo, A.R.B., ViÉGas, R.A., OliveIRA, J.T.A. (2001) Salinity-induced effects on nitrogen assimilation related to growth in cowpea plants. Environmental and Experimental Botany, 46, 171-179.

SMART, C. (1994) Gene expression during leaf čnescence. New Phytologist, 126, 419-448.

Spano, G., Di Fonzo, N., Perrotta, C., Platani, C., Ronga, G., Lawlor, D.W., Napier, J.A., SHEWRY, P.R. (2003) Physiological characterization of 'stay-green' mutants in durum wheat. Journal of Experimental Botany, 54, 1415-1420.

Swarup, R., Benett, M.J., Cullimore, J.V. (1990) Expression of glutamine-synthetase genes in cotyledons of germinating Phaseolus vulgaris L. Planta, 183, 51-56.

Tabuchi, M., Sugiyama, K., Ishiyama, K., Inoue, E., Sato, T., Takahashi, H., Yamaya, T. (2005) Severe reduction in growth rate and grain filling of rice mutants lacking OsGS1;1, a cytosolic glutamine synthetase1;1. The Plant Journal, 42, 641-651.

Tari, I., Guóth, A., Benyó, D., Kovács, J., PoÓr, P., Wodala, B., (2010) The roles of ABA, reactive oxygen species and nitric oxide in root growth during osmotic stress in wheat: Comparison of a tolerand and a sensitive variety. Acta Biologica Hungarica, 61, 189-196.

TAYLOR, G. J., (1991) Current views of the aluminium stress response; the physiological basis of tolerance. Current Topics in Plant Biochemistry and Physiology, 10, 57-93.

TeIXeIrA, J., Pereira, S. (2007) High salinity and drought act on an organ-dependent manner on potato glutamine synthetase expression and accumulation. Environmental and Experimental Botany, 60, 121-126. 
VANCE, C.P., Griffith, S.M. (1990) The molecular biology of N metabolism. In: Dennis, D.T., Turpin, D.H. Eds. Plant physiology, biochemistry and molecular biology, Longman House, Harlow, England. pp. 383-388.

Versalus, P.E., Agarwal, M., Katiyar-Agarwal, S., Zhu, J., Zhu, J.-K. (2006) Methods and concepts in quantifying resistance to drought, salt and freezing, abiotic stresses that affect plant water status. The Plant Journal, 45, 523-539.

Wiedemuth, K., Müller, J., Kahlau, A., Amme, S., Mock, H., Grzam, A., Hell, R., EgLe, K., Beschow, H., HumBeCK, K. (2005) Succesive maturation and senescence of individual leaves during barley whole plant ontogeny reveals temporal and spatial regulation of photosynthetic function in conjuction with $\mathrm{C}$ and $\mathrm{N}$ metabolism. Journal of Plant Physiology, 162, 1226-1236.

Yamauchi, Y., Sugimoto, T., Sueyosh, K., Oji, Y., TanaKa, K. (2002) Appearance of endopeptidases during leaf senescence of cucumber leaves. Plant Science, 162, 615-619.

YANG, Z.M., Sivaguru, M., Horst, W.J., Matsumoto, H. (2000) Aluminium tolerance is achived by exudation of citric acid from roots of soybean (Glycine max). Physiologia Plantarum, 110, 72-77.

YANG, J., ZHANG, J. (2005) Grain filling of cereals under soil drying. New Phytologist, 169, 223-236.

Zadoks, J.C., Chang, T.T., KonZAK, C.F. (1974) A decimal code for the growth stages of cereals. Weed Research, 14, 415-421.

Zatta, P., Zambenedetti, P., BrunA, V., FilipPi, B. (1994) Activation of acetycholinesterase by aluminium(III): the relevance of the metal species. Neuro Report, 5, 1777-1780.

ZhaO, X.-Q., SHI, W.-M. (2006) Expression analysis of the glutamine synthetase and glutamate synthase gene families in young rice (Oryza sativa) seedlings. Plant Science, 170, 748-754.

Zhang, J., JiA, W., YAng J., Ismail, A.M. (2006) Role of ABA in integrating plant responses to drought and salt stresses. Field Crops Research, 97, 111-119.

Zheng-Xun, J., ChUn-RONG, Q., Jing, Y., HAI-YING, L., ZhONG-ZE, P. (2007) Changes in activities of glutamine synthetase during grain filling and their relation to rice quality. Rice Science, 14, 211-216.

ZHU, J.K., LIU, J., XIONG, L. (1998) Genetic analysis of salt tolerance in Arabidopsis thaliana. Plant Cell, 10,1181-1192. 
Zozaya-Hinchliffe, M., Potenza, C., Ortega, J.L., Sengupta-Gopalan, C. (2005) Nitrogen and metabolic regulation of the expression of plastidic glutamine synthetase in alfalfa (Medicago sativa). Plant Science, 168, 1041-1052.

Zsoldos, F., Haunold, E., VAshegyi, Á. (1986) The effects of phosphate supply on uptake of potassium ions, 2,4-D and atrazine by wheat and maize. Physiologia Plantarum, 68, 154-158. 